June 2001 • NREL/TP-510-29417

\title{
Microalgae Production from Power Plant Flue Gas: Environmental Implications on a Life Cycle Basis
}

Kiran L. Kadam
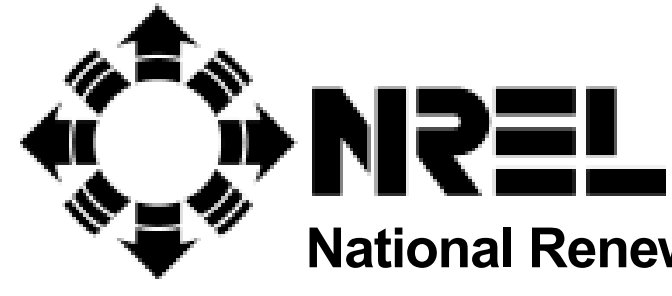

National Renewable Energy Laboratory

1617 Cole Boulevard

Golden, Colorado 80401-3393

NREL is a U.S. Department of Energy Laboratory

Operated by Midwest Research Institute • Battelle • Bechtel

Contract No. DE-AC36-99-G010337 


\section{Microalgae Production from Power Plant Flue Gas: Environmental Implications on a Life Cycle Basis}

\section{Kiran L. Kadam}

Prepared under Task No. DO11.4010

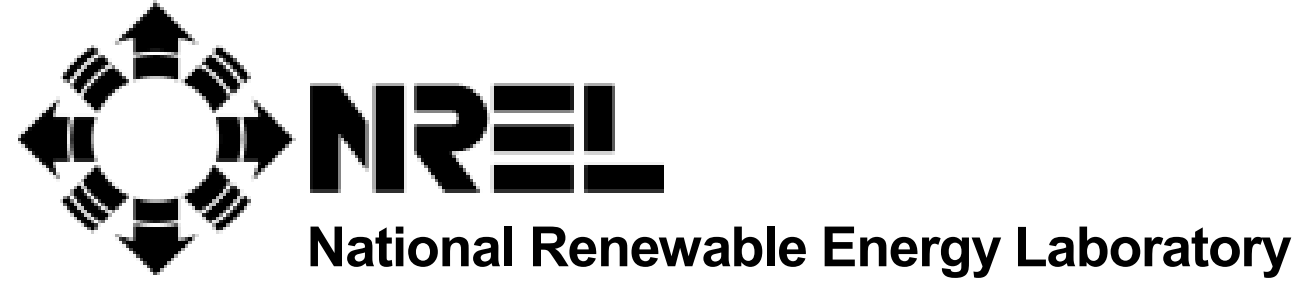

1617 Cole Boulevard

Golden, Colorado 80401-3393

NREL is a U.S. Department of Energy Laboratory

Operated by Midwest Research Institute $\bullet$ Battelle $\bullet$ Bechtel

Contract No. DE-AC36-99-G010337 


\section{NOTICE}

This report was prepared as an account of work sponsored by an agency of the United States government. Neither the United States government nor any agency thereof, nor any of their employees, makes any warranty, express or implied, or assumes any legal liability or responsibility for the accuracy, completeness, or usefulness of any information, apparatus, product, or process disclosed, or represents that its use would not infringe privately owned rights. Reference herein to any specific commercial product, process, or service by trade name, trademark, manufacturer, or otherwise does not necessarily constitute or imply its endorsement, recommendation, or favoring by the United States government or any agency thereof. The views and opinions of authors expressed herein do not necessarily state or reflect those of the United States government or any agency thereof.

Available electronically at http://www.doe.gov/bridge

Available for a processing fee to U.S. Department of Energy

and its contractors, in paper, from:

U.S. Department of Energy

Office of Scientific and Technical Information

P.O. Box 62

Oak Ridge, TN 37831-0062

phone: 865.576.8401

fax: 865.576.5728

email: reports@adonis.osti.gov

Available for sale to the public, in paper, from:

U.S. Department of Commerce

National Technical Information Service

5285 Port Royal Road

Springfield, VA 22161

phone: 800.553.6847

fax: 703.605.6900

email: orders@ntis.fedworld.gov

online ordering: http://www.ntis.gov/ordering.htm

Printed on paper containing at least $50 \%$ wastepaper, including $20 \%$ postconsumer waste 


\section{Table of Contents}

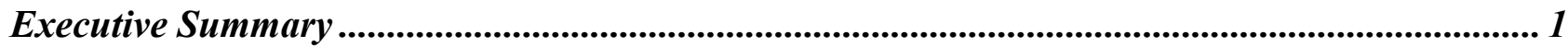

Background ................................................................................................................................................ 1

Key LCA Results ............................................................................................................................. 1

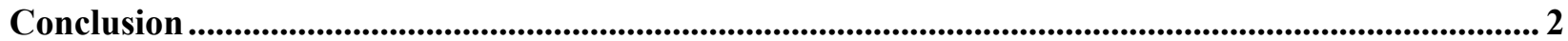

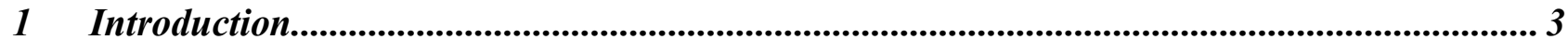

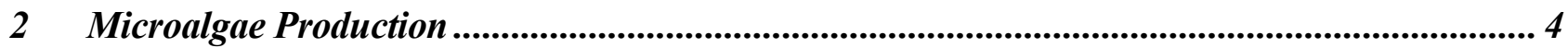

$2.1 \quad \mathrm{CO}_{2}$ Recovery ..................................................................................................................... 4

Resource Assessment................................................................................................................................... 5

3 Project Scope .................................................................................................................. 5

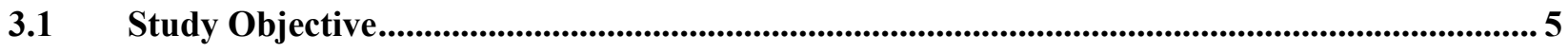

3.2 Life Cycle Assessment Principles ............................................................................................. 5

3.3 Methodology ...................................................................................................................................

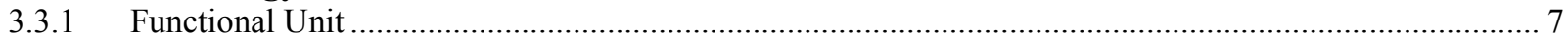

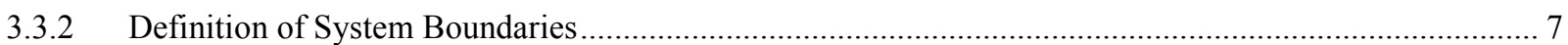

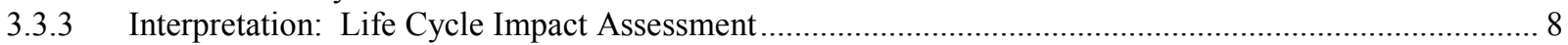

$4 \quad$ Scoping Options and Decisions............................................................................................ 8

4.1 Project Parameters............................................................................................................. 9

4.1.1 General System Boundaries ................................................................................................................... 9

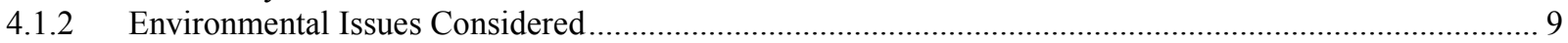

4.1.3 Geographical Scope …………………………………………………………………………….. 12

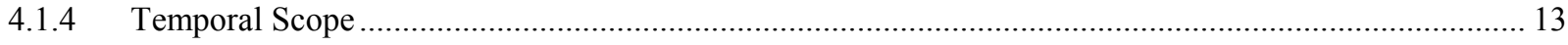

4.2 Product Parameters..................................................................................................... 13

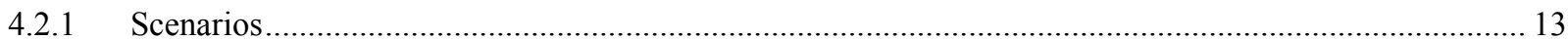

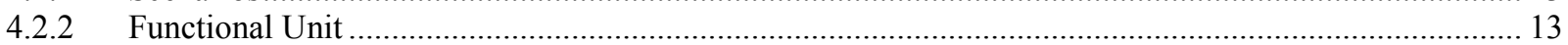

4.3 Process Parameters .......................................................................................................... 13

4.4 LCA-Specific Parameters ............................................................................................. 14

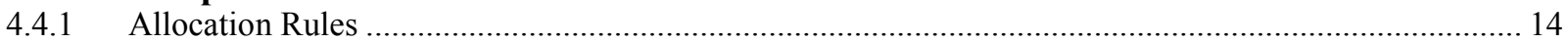

4.5 Summary of Scoping Decisions and Approaches............................................................................ 14

$5 \quad$ Life Cycle Modeling...................................................................................................................... 15

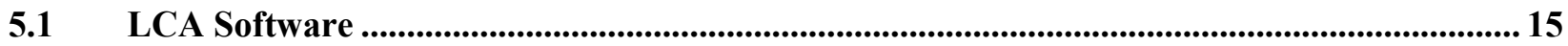

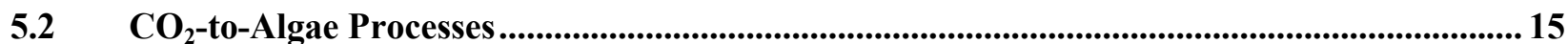

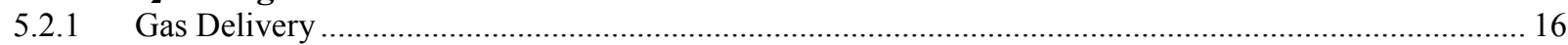

5.2.2 MEA Process …………………………………………………………………………………… 16

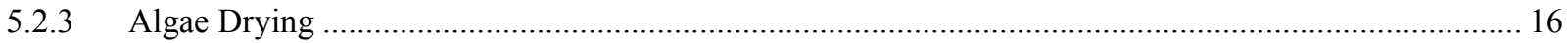

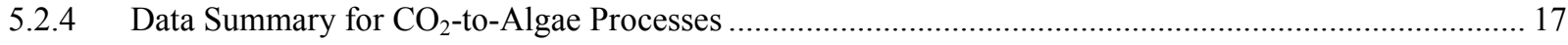

5.3 Electricity Production .................................................................................................... 18

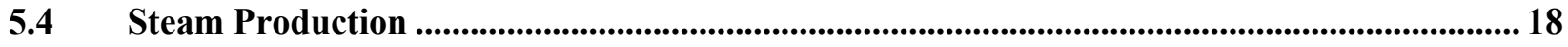

$5.5 \quad \mathrm{CO}_{2}$ Accounting ………................................................................................................................ 19 
6 Data Quality and Sources................................................................................................... 19

6.1 Data Sources................................................................................................................................ 19

6.2 Data Quality ........................................................................................................................ 19

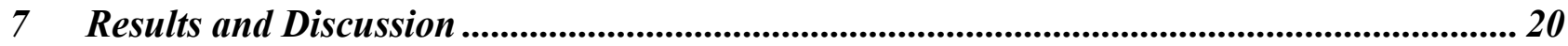

7.1 Presentation of Results ............................................................................................................. 20

7.2 Time-Space Implications of Emissions .............................................................................. 20

7.3 Life Cycle Energy Balance........................................................................................................ 21

7.4 LCI for Coal Firing versus Coal/Algae Cofiring: Direct Injection Process ................................ 22

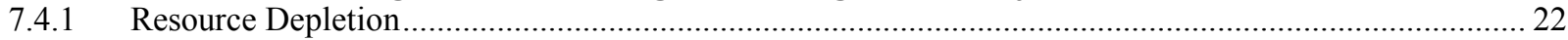

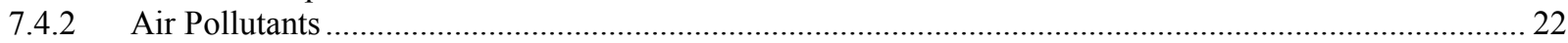

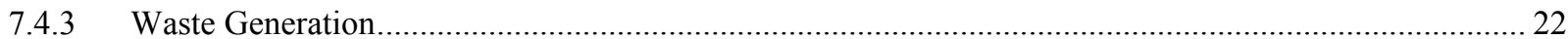

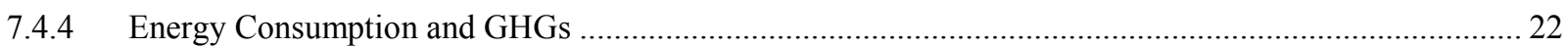

7.5 LCI for Coal Firing versus Coal/Algae Cofiring: MEA Process................................................ 31

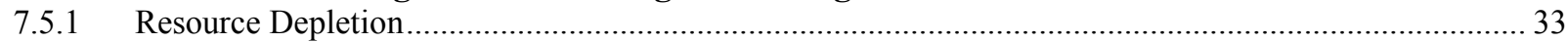

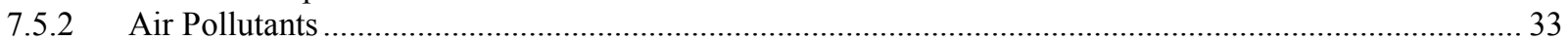

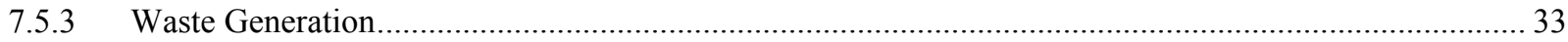

7.6 Sensitivity Analysis on Drying Processes.....................................................................................33

7.7 LCIA for Coal Firing versus Coal/Algae Cofiring .......................................................................33

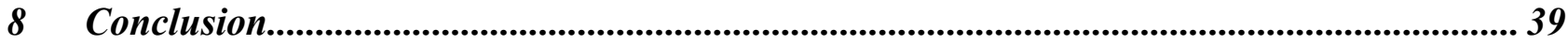

References ................................................................................................................................ 40

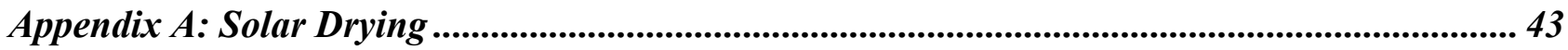

Crop Drying ............................................................................................................................................ 43

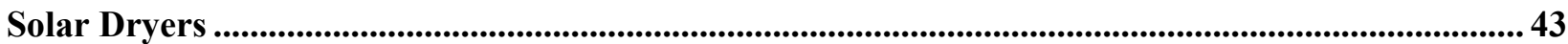

Flat-Plate Collector with Cover...…………………………………………………………………………. 44

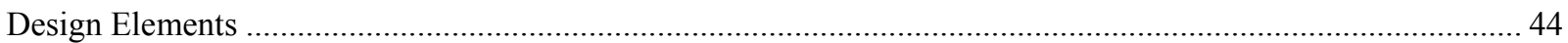

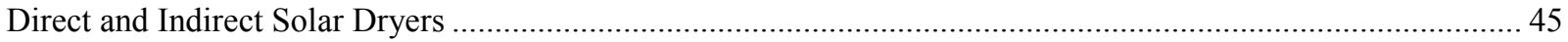

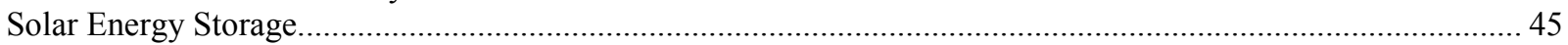

Solar Kiln ................................................................................................................................................ 47

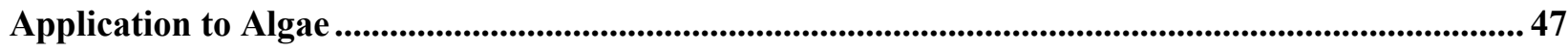

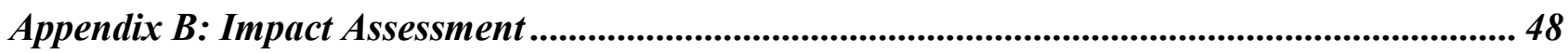

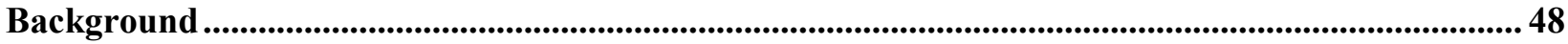

Overview of Life Cycle Impact Assessment Indices ..............................................................................50

Greenhouse Potential .................................................................................................................................. 50

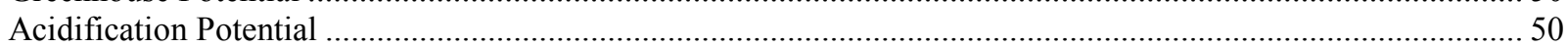

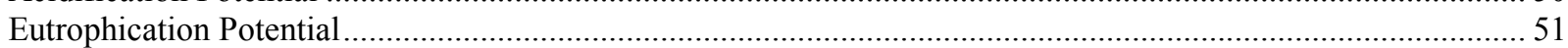

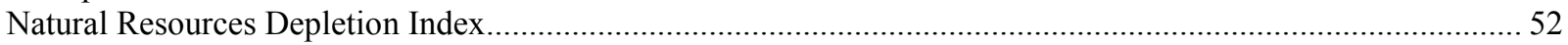

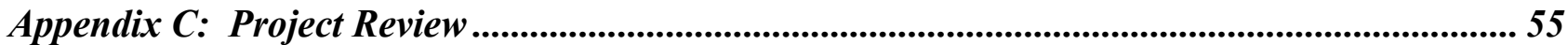




\section{List of Tables}

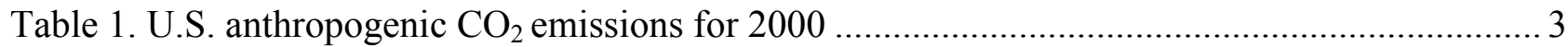

Table 2. Environmental inventory flows considered in the study........................................... 12

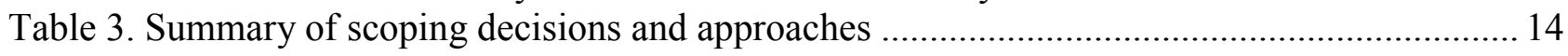

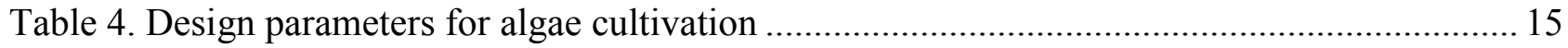

Table 5. Data summary for algae cultivation in a 1000-ha system............................................ 17

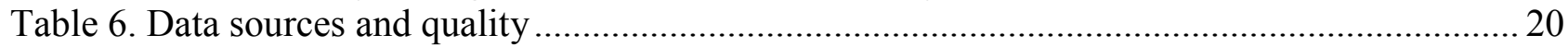

Table 7. Life cycle inventory for coal firing versus coal/algae cofiring: Direct injection process (solar drying).................................................................................................. 23

Table 8. Key environmental flows for selected modules: non-renewable resource consumption, air

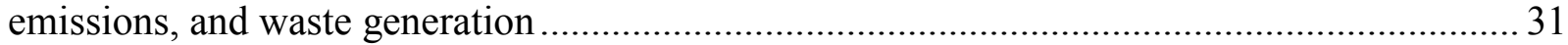

Table 9. Key environmental flows for selected modules: GHG emissions .................................. 31

Table 10. Life cycle inventory for coal firing versus coal/algae cofiring: MEA Process (solar

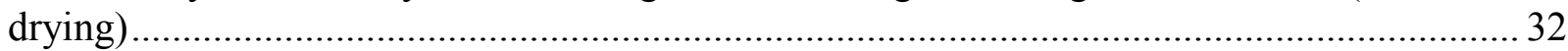

Table 11. Life cycle inventory for coal firing versus coal/algae cofiring: Direct injection process

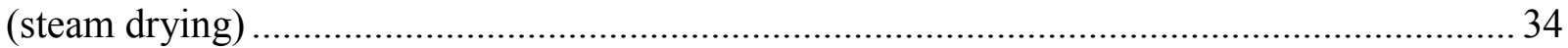

Table 12. Life cycle inventory for coal firing versus coal/algae cofiring: MEA process (steam

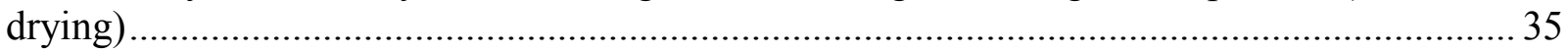

Table 13. Life cycle impact assessment for coal firing versus coal/algae cofiring: Direct injection

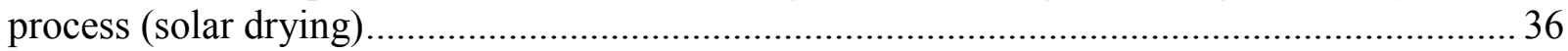

Table 14. Life cycle impact assessment for coal firing versus coal/algae cofiring: MEA process

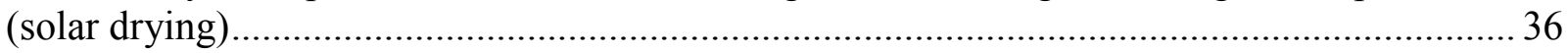

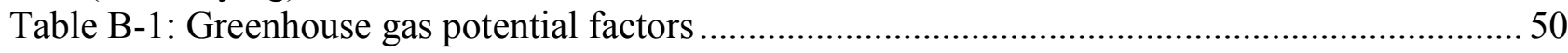

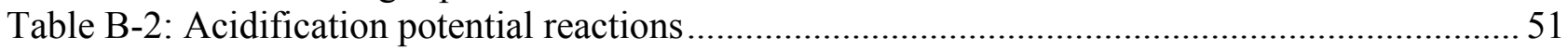

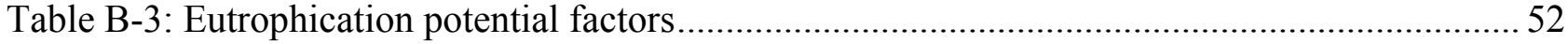




\section{List of Figures}

Figure 1. Schematic representation of extending system boundaries. .......................................... 6

Figure 2. Elements of the scoping phase for life cycle analysis............................................... 9

Figure 3. General system boundaries for the comparison of electricity production via coal firing

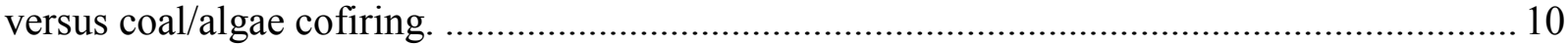

Figure 4. A simplified flow diagram for microalgae production. .............................................. 16

Figure 5. Coal usage for coal firing versus coal/algae cofiring. .................................................. 24

Figure 6. Natural gas usage for coal firing versus coal/algae cofiring. ...................................... 24

Figure 7. Crude oil usage for coal firing versus coal/algae cofiring......................................... 25

Figure 8. Carbon monoxide emissions for coal firing versus coal/algae cofiring......................... 25

Figure 9. Fossil $\mathrm{CO}_{2}$ emissions for coal firing versus coal/algae cofiring .................................. 26

Figure 10. Hydrocarbon (except methane) emissions for coal firing versus coal/algae cofiring. ..... 26

Figure 11. Methane emissions for coal firing versus coal/algae cofiring. .................................... 27

Figure 12. Nitrogen oxides $\left(\mathrm{NO}_{\mathrm{x}}\right.$ as $\left.\mathrm{NO}_{2}\right)$ emissions for coal firing versus coal/algae cofiring...... 27

Figure 13. Nitrous oxide emissions for coal firing versus coal/algae cofiring............................ 28

Figure 14. PM10 emissions for coal firing versus coal/algae cofiring. ...................................... 28

Figure 15. Particulate matter (unspecified) emissions for coal firing versus coal/algae cofiring......29

Figure 16. Sulfur oxides $\left(\mathrm{SO}_{\mathrm{x}}\right.$ as $\left.\mathrm{SO}_{2}\right)$ emissions for coal firing versus coal/algae cofiring............ 29

Figure 17. Total solid waste produced for coal firing versus coal/algae cofiring.......................... 30

Figure 18. Process energy required for coal firing versus coal/algae cofiring. .............................. 30

Figure 19. Greenhouse effect for coal firing versus coal/algae cofiring.................................... 37

Figure 20. Air acidification potential for coal firing versus coal/algae cofiring........................... 37

Figure 21. Natural resource depletion potential for coal firing versus coal/algae cofiring. ............. 38

Figure 22. Eutrophication potential for coal firing versus coal/algae cofiring............................. 38

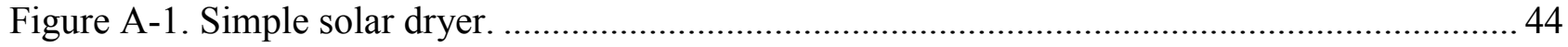

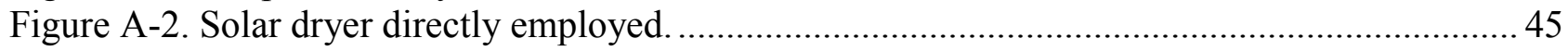

Figure A-3. Solar dryer indirectly employed.................................................................... 46

Figure A-4. Schematic of an indirect solar dryer system.................................................. 46

Figure B-1: Life cycle impact assessment framework........................................................ 49 


\section{EXECUTIVE SUMMARY}

\section{Background}

Electrical power plants are responsible for over one-third of the U.S. emissions or about $2.2 \times 10^{9} \mathrm{t}$ carbon dioxide $\left(\mathrm{CO}_{2}\right)$ per year. Power-plant flue gas can serve as a source of $\mathrm{CO}_{2}$ for microalgae cultivation, and the algae can be cofired with coal. The study objective was to conduct a life cycle assessment (LCA) to quantify the environmental benefits of recycling $\mathrm{CO}_{2}$ from power plants for microalgae production. Specifically, electricity production via coal firing versus coal/algae cofiring was compared.

\section{Key LCA Results}

The LCA, which accounts for all the inputs and outputs to a given process option, demonstrates that there are potentially significant benefits to recycling $\mathrm{CO}_{2}$ toward microalgae production. Based on the LCA results, lower net values for the algae cofiring scenario were observed for the following using the direct injection process (in which the flue gas is directly transported to the algae ponds):

- $\mathrm{SO}_{\mathrm{x}}$ and $\mathrm{NO}_{\mathrm{x}}$

- Particulates

- $\mathrm{CO}_{2}$ and methane

- Fossil energy consumption

Carbon monoxide and hydrocarbons (except methane) emissions were statistically similar. However, the algae cofiring scenario exhibited higher water-borne emissions as indicated by the chemical oxygen demand (COD) values.

Four impact assessment categories were also evaluated to further illuminate the differences between the two scenarios: greenhouse potential, depletion of natural resources, air acidification potential, and eutrophication potential. The lower emissions of greenhouse gases (GHGs) such as carbon dioxide and methane emissions - although not regulated or mandated by state or national laws - are also desirable attributes as they lead to lower greenhouse potential for the coal/algae cofiring scenario. Lower values for the algae cofiring scenario, when compared to the coal-firing scenario, were also observed for the impact assessment category of air acidification potential. However, impact assessment for depletion of natural resources and eutrophication potential showed much higher values. For Scenario 2, the higher depletion of natural resources results from higher consumption of natural gas and oil, which have lower reserves than coal. When coal is displaced by algae, its positive impact is smaller due to larger coal reserves. In other words, if a natural gas fired plant were considered, depletion of natural resources would not be as high for Scenario 2. The eutrophication potential values are higher because of fertilizer consumption during algae production. Fertilizer production results in relatively high COD values and phosphate emissions, and only the algae cofiring scenario has this particular burden. 


\section{Conclusion}

The algae cofiring scenario distinguishes itself by demonstrating lower GHG (a global unregulated environmental criterion) and air pollutant burdens (local regulated environmental criteria). However, these benefits have to be balanced with higher natural gas and oil consumption and higher eutrophication potential. This LCA gives us an overall picture of impacts across different environmental boundaries. Hence, it can help the decision-making process at companies like Rio Tinto Energy Group (a mining/energy company in Australia) and Arizona Public Service that are considering microalgae production as an avenue for GHG mitigation. 


\section{INTRODUCTION}

The United States generates about $5.7 \mathrm{Gt}\left(\mathrm{G} \equiv 10^{9}\right)$ of carbon dioxide $\left(\mathrm{CO}_{2}\right)$ per year amounting to about $22 \%$ of the worldwide anthropogenic emissions. U.S. anthropogenic $\mathrm{CO}_{2}$ emissions for 2000 are listed by sector in Table 1 (EIA 2000). Electrical power plants are responsible for $38 \%$ the U.S. emissions and 7\% of the world's $\mathrm{CO}_{2}$ emissions from energy use (USDOE 2000).

$\mathrm{CO}_{2}$ is a major greenhouse gas (GHG), and its physical capture from fossil-fuel power-plants has been considered as a potential remediation option since Marchetti (1977) first proposed the disposal of the captured $\mathrm{CO}_{2}$ in the deep ocean. Several investigators have since studied a plethora of options for $\mathrm{CO}_{2}$ capture from power plants - which are stationary, concentrated sources of the gas - and its subsequent disposal or use. Thus, $\mathrm{CO}_{2}$ capture is a common step for most of the remediation options.

Table 1. U.S. anthropogenic $\mathrm{CO}_{2}$ emissions for 2000

\begin{tabular}{lccc}
\hline Sector & $\begin{array}{c}\text { Gt of } \\
\text { carbon/year }\end{array}$ & $\begin{array}{c}\text { Gt of } \\
\mathbf{C O}_{2} / \text { year }\end{array}$ & \% of Total \\
\hline Transportation & 517 & 1896 & 33.3 \\
Industrial & 470 & 1723 & 30.3 \\
Commercial & 259 & 950 & 16.7 \\
Residential & 306 & 1122 & 19.7 \\
Total & 1552 & 5691 & 100.0 \\
\hline
\end{tabular}

In a general assessment of alternative processes for capturing $\mathrm{CO}_{2}$ from existing coal-fired power plants, Herzog et al. (1991) concluded that capture is currently technically feasible, but that the most efficient available technology will reduce energy efficiency of utility steam plants by about $30 \%$ and will increase the price of electricity by $80 \%$, even before disposal costs are added. These results are consistent with a study by the Electric Power Research Institute (EPRI) on $\mathrm{CO}_{2}$ capture and disposal (Booras and Smelser 1991). Emerging and future electricity generation technologies have the potential to significantly reduce these costs.

Besides disposal, another potential sequestration option is to find recycle opportunities for power plant $\mathrm{CO}_{2}$ as a feedstock for industrial products or processes or as a component of alternative fuels. For $\mathrm{CO}_{2}$ recovery, the monoethanolamine (MEA) absorption process is commonly employed and is the heart of the steam host requirement. The two commercial U.S. $\mathrm{CO}_{2}$ recovery facilities use MEA absorption technologies and produce a food- and beverage-grade product. The total industrial utilization of $\mathrm{CO}_{2}$ today in the U.S. is about $2 \%$ of the $\mathrm{CO}_{2}$ generated from power plants. However, in about $80 \%$ of the applications, as in enhanced oil recovery (EOR) and the food industry, $\mathrm{CO}_{2}$ used is rapidly returned to the atmosphere. While niches may be found for some utilization, it is unlikely that industrial use can sequester more than a minor fraction of the emitted $\mathrm{CO}_{2}$ from power plants. Use in fuels is feasible, but external energy inputs required to synthesize the fuels can be much more efficiently used to serve energy markets directly. Conversion of $\mathrm{CO}_{2}$ to microalgae is also a sequestration option; however, as in any other option, efficient recovery and delivery of the $\mathrm{CO}_{2}$ are critical. 
This study discusses the environmental implications of using power-plant flue gas as a source of $\mathrm{CO}_{2}$ for microalgae cultivation and cofiring the algae with coal for electricity production.

\section{MICROALGAE PRODUCTION}

Microalgae are unique photosynthetic organisms given that they accumulate storage lipids in substantial quantities and thrive in high salinity water. In the United States, microalgae pondsystems are envisioned to be located in the desert Southwest because this area offers flat land, high incident solar radiation, few competing land uses, and large reservoirs of saline water. This minimizes land costs, while the use of saline water, not suitable for agricultural, domestic, or industrial purposes, minimizes competition with other uses for the limited supplies of fresh water in the Southwest. The algal mass produced from power plant $\mathrm{CO}_{2}$ is a useful product with application in food, fuels, etc. The production of lipids from microalgae is a possibility because plant storage lipids could be among the best biomass feedstocks for producing renewable, high-energy liquid fuels such as diesel fuel. Alternatively, cofiring the algae with coal for electricity production is the option considered in this study, as this is a simpler approach not requiring extensive post-cultivation processing. Furthermore, unlike soybean-based biodiesel, the hexane emissions can be substantial for microalgae-based biodiesel (unpublished data).

\section{1 $\mathrm{CO}_{2}$ Recovery}

Previous analysis has shown that $\mathrm{CO}_{2}$ cost plays a central role in process economics, making the minimization of $\mathrm{CO}_{2}$ cost a top priority (Kadam and Sheehan 1996). A rigorously derived $\mathrm{CO}_{2}$ recovery-cost model is available in the context of microalgae cultivation using flue gas emitted by a typical $500 \mathrm{MW}$ power plant located in the Southwestern United States (Kadam 1997). This model assumes a transportation distance of $100 \mathrm{~km}$ and night storage of $\mathrm{CO}_{2}$ in the pipelines. The standard process includes MEA extraction, compression, dehydration, and transportation to the ponds, and produces a gas that is almost $100 \% \mathrm{CO}_{2}$. To evaluate if the flue gas could be directly utilized, an alternative case was devised that only includes compression, dehydration, and transportation to the ponds. This option delivers $\mathrm{CO}_{2}$ to the ponds at a concentration of only $14 \%$. Processing of flue-gas equivalent to a $50 \mathrm{MW}$ capacity was also analyzed since it matches well with the $\mathrm{CO}_{2}$ mitigation capacity of a 1000 ha pond system.

The comparison of processing options in the above study showed that the MEA extraction was less expensive than the direct pumping option as a penalty is levied on the latter in the form of compressing and transporting a seven-fold higher gas volume. However, as compression is costly and energy-intensive, the best strategy may be to eliminate it altogether. The direct pumping option should then be more economical. In the direct pumping scheme, night storage of $\mathrm{CO}_{2}$ in the pipelines is not feasible and only a part of the emitted $\mathrm{CO}_{2}$ can then be used for algae production. In this analysis this simpler and more economical approach of direct pumping was used. 


\section{Resource Assessment}

Kadam and Brady (1996) conducted a geographical information system (GIS) based resource assessment study for algae production using $\mathrm{CO}_{2}$ from the San Juan power plant (1800 MW) owned by Public Service of New Mexico (PNM). They concluded that a pond system capable of mitigating at least enough $\mathrm{CO}_{2}$ from one $500 \mathrm{MW}$ unit is feasible. However, a $50 \mathrm{MW}$ capacity is assumed for this analysis, which corresponds to about a 1000 ha pond system and total $\mathrm{CO}_{2}$ emissions of about $414,000 \mathrm{t} / \mathrm{yr}$. It should, however, be noted that the size of the pond system does not affect the life cycle assessment (LCA) results which are normalized based on $1 \mathrm{MW}$ of electricity produced.

\section{PROJECT SCOPE}

\subsection{Study Objective}

The study objective is to conduct an LCA to quantify the environmental implications of using power-plant flue gas as a source of $\mathrm{CO}_{2}$ for microalgae cultivation and cofiring the algae with coal for electricity production. This approach is compared with the status quo of electricity production using coal alone. The LCA results would serve as a basis in the decision-making process for implementing the algae scenario.

\subsection{Life Cycle Assessment Principles}

LCA is a technique for assessing the environmental aspects and potential impacts associated with a product, by:

- Compiling an inventory of relevant inputs and outputs of a system (life cycle inventory [LCI])

- Evaluating the potential environmental impacts associated with those inputs and outputs

- Interpreting the results of the inventory and impacts in relation to the objectives of the study.

LCA studies the environmental aspects and potential impacts throughout a product's life (i.e., from cradle to grave) from raw material acquisition through production, use, and disposal. The general principle for extending the system boundaries, to include various processes involved in producing and using a product, is illustrated in Figure 1.

In the most straightforward and transparent approach to LCI interpretation, the inventory results may be used on an "as-is" basis to help identify and prioritize opportunities for pollution prevention or increases in material and energy efficiency for processes within the life cycle. A particular advantage of LCI applied in this way is its comprehensiveness. LCAs help detect the shifting of environmental burdens from one life cycle stage to another (e.g., lower energy consumption during use, achieved at the cost of much higher manufacturing energy consumption), or from one medium to another (e.g., lower air emissions at the cost of increased solid waste). 


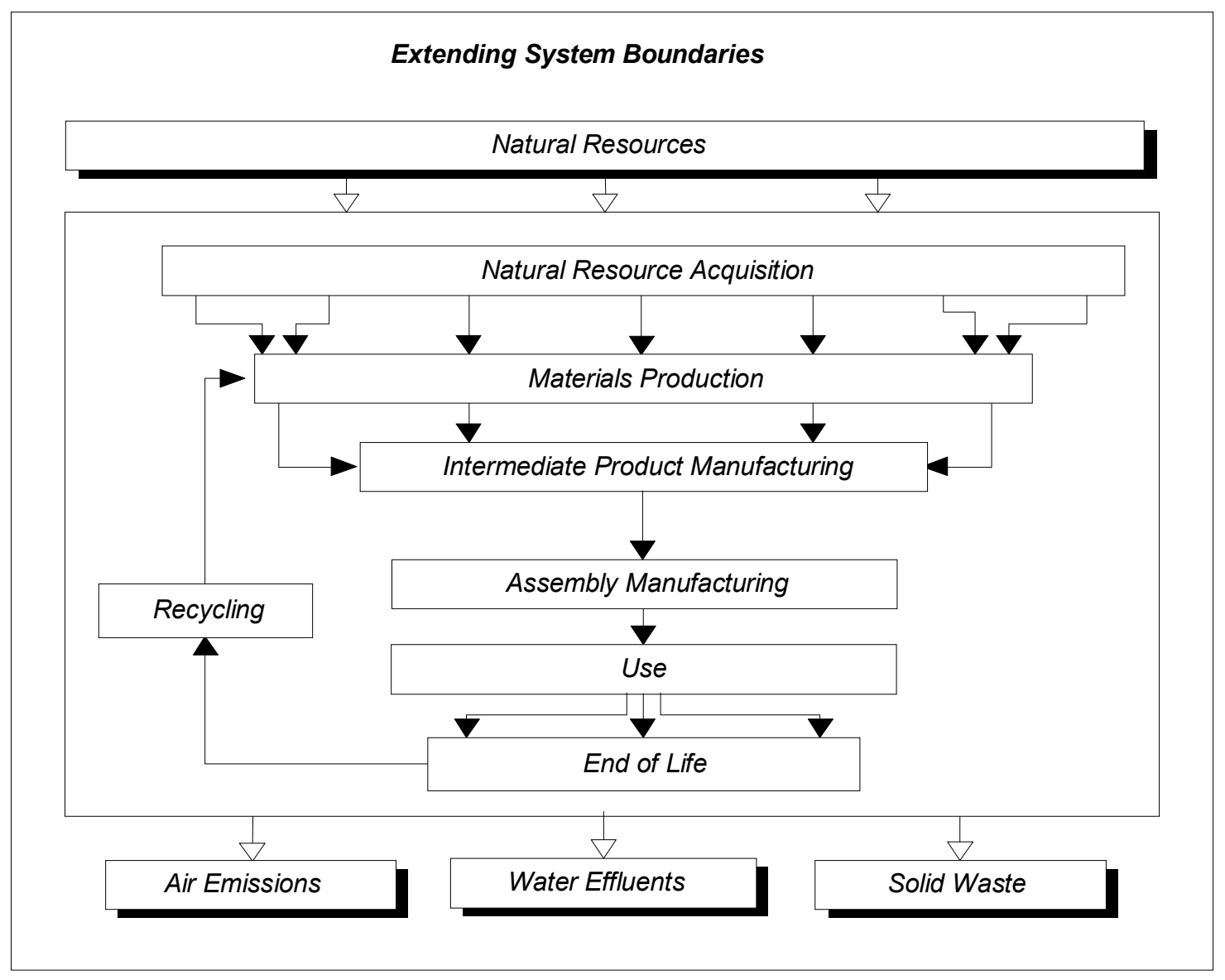

Figure 1. Schematic representation of extending system boundaries.

Because the number of flows calculated during an LCI analysis is often very large, subsets of the flows are sometimes consolidated or aggregated to facilitate interpretation, especially when two or more products or processes are being compared using LCA. This consolidation and aggregation of flows has been given the (perhaps misleading) name of life cycle impact assessment (LCIA). In fact, it is not the impacts of the environmental flows in the inventory that are estimated using LCIA. Instead, the inventory flows are consolidated and aggregated using information about their relative potential strength of influence on separate categories of potential environmental impacts, thereby generating indicators. The results within each LCIA impact category are useful for comparing one product or process with another, but have little meaning in an absolute sense (i.e., relative to estimating the actual environmental impacts of a product or process).

Because the results of an LCI and an LCIA are influenced by a significant number of assumptions and uncertainties, the interpretation phase usually includes some sensitivity analyses. This allows an assessment of the robustness of the baseline results, project assumptions, methodological choices, future scenarios, and uncertainties. In this study, data quality was assessed for its 1) precision, 2) completeness, 3) representativeness, 4) consistency, and 5) the origin of the data (measured, calculated, or estimated). 
Principal aspects of LCI and LCIA are discussed briefly in the sections that follow. Further information about LCA methodology is provided in a number of publications from the Society of Environmental Toxicology and Chemistry (SETAC 1991; SETAC 1993a; SETAC 1993b; SETAC 1994), the U.S. Environmental Protection Agency (EPA) (EPA 1993a; EPA 1993b; EPA 1995a), the International Organization for Standardization (ISO 1996; ISO 1997), as well as other sources (Heijungs et al. 1992; SETAC-Europe 1992).

\subsection{Methodology}

\subsubsection{Functional Unit}

The comparison of different industrial systems can only be achieved if they perform the same function. Once this shared function is defined; a unit must be chosen in order to compare the systems on the same quantitative basis. All the energy and mass flows in the inventory are normalized to this functional unit. Examples of how this is done are presented below.

- The comparison of different indoor paints (solvent-borne, water-borne, etc.) could be made on the following basis:

* Function: covering a surface

* Functional unit: the quantity of paint required to cover $5 \mathrm{~m}^{2}$ of wall (this function could be further refined to take into account secondary functions like opacity, washability, durability and lifetime, etc.)

- The comparison of different transportation fuels could be made on the following basis:

* Function: energy needed to travel $1 \mathrm{~km}$

* Functional unit: the quantity of transportation fuel required to provide the necessary energy

\subsubsection{Definition of System Boundaries}

For each option being compared on a life-cycle basis, the corresponding systems are then determined (i.e., relevant processes to be included in the system are selected). The three main issues to address, for each of the systems, are discussed below.

1) Exhaustivity of the systems. The LCA theoretical principle implies that each material and constituent be studied and traced back to natural resources, and forward through final disposal. The strict application of this principle would lead to the study of almost every industrial process, because all industrial operations work within a complex network. In order to focus LCA projects on the main operations, quantitative rules are applied to exclude the constituents and ancillary materials whose impacts are estimated to be negligible compared to those of the overall studied system.

2) Identification of steps/operations that are different from one system to another. As the project focuses on a comparison, steps that are functionally equivalent for the compared products could be excluded from both systems. On the other hand, steps or operations that are not functionally equivalent for the compared products should be taken into account and included in the system boundaries.

3) Identification of coproducts and determination of the appropriate partitioning parameter. This facilitates proper allocation of a defined product's share of the total pollution, energy consumption, and material flows for which the process is responsible. 


\subsubsection{Interpretation: Life Cycle Impact Assessment}

In this element of the LCA, after the inventory has been prepared, two further steps that need to be considered:

1) Whether and how to aggregate and/or consolidate the inventory data using information about each flow's relative potential strength of influence with respect to separate categories of potential environmental impact; and

2) Whether and how to aggregate the results of the step mentioned above, across the impact categories considered.

Note that the first of these two steps is pursued in addition to the LCIA, not as a replacement for it. Those attempting to develop a final "score" for comparing products or processes only use the second of these two aggregation steps. It was not used in this project because it requires value judgments (e.g., is water pollution more sinister than air pollution?), which are beyond the scope of this analysis.

\section{SCOPING OPTIONS AND DECISIONS}

This section presents the various parameters that should be considered in order to precisely define the scope of the project. These parameters can be addressed sequentially, as indicated in Figure 2. The process begins by first considering "project" level parameters that involve high-level choices that can have a profound impact on the general orientation and outcome of the project. These choices involve geographic, temporal, technical, and environmental aspects of the life cycle scenarios being studied. Next, we need to consider more specific product parameters, including the exact nature and form of the products studied and the type of application in which they are used. The third group of parameters involves the production processes used to make the product. The types of choices made for high-level project parameters influence both product- and process-related parameters. Finally, a group of parameters must be defined regarding the LCA methodology itself.

Subsequent sections address the separate scoping elements in turn, as follows:

$\begin{array}{lll}\text { Project Parameters } & \Rightarrow & \text { Section 4.1 } \\ \text { Product Parameters } & \Rightarrow & \text { Section 4.2 } \\ \text { Process Parameters } & \Rightarrow & \text { Section 4.3 } \\ \text { LCA-Specific Parameters } & \Rightarrow & \text { Section 4.4 }\end{array}$


The key criteria that have been employed in selecting an option for each parameter are:

- Relevance to the project's goals

- Availability of data

- Time and cost constraints

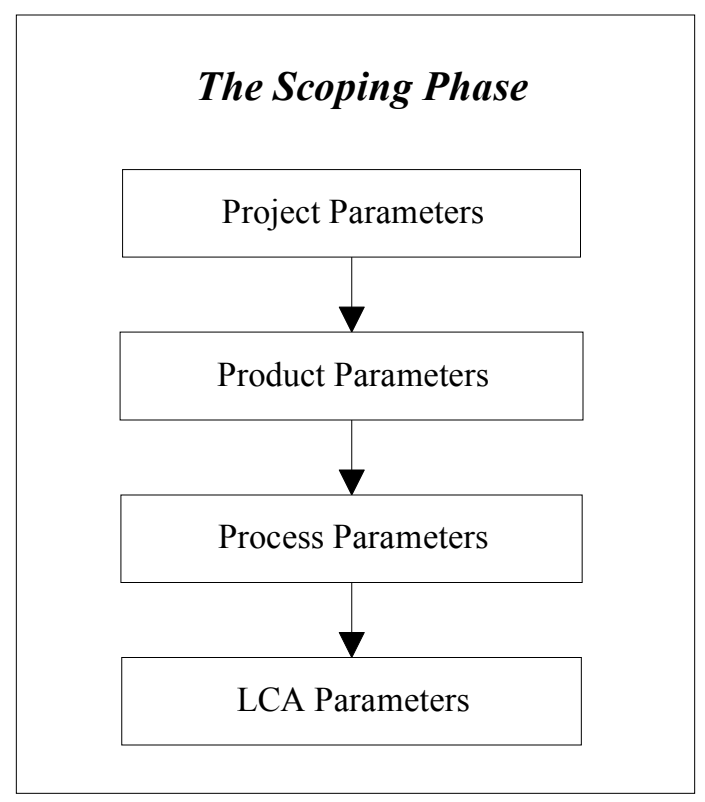

Figure 2. Elements of the scoping phase for life cycle analysis.

\subsection{Project Parameters}

\subsubsection{General System Boundaries}

Figure 3 shows the general system boundaries for the two scenarios considered in this study. In one scenario, electricity is produced using coal alone (Scenario 1). In the alternative scenario, powerplant flue gas is used as a source of $\mathrm{CO}_{2}$ for microalgae cultivation and the algae is cofired with coal for electricity production (Scenario 2). Electricity production using coal represents the status quo; this LCA compares cofiring of microalgae, produced from flue-gas $\mathrm{CO}_{2}$, with the status quo.

\subsubsection{Environmental Issues Considered}

The LCA methodology traditionally calls for complete mass and energy balances for each process, including energy consumption, raw material consumption, air emissions, water effluents, and solid waste. This comprehensive compilation exercise results in a quantification of all existing flows into the environment. However, this scheme has become increasingly questionable for the following reasons: 


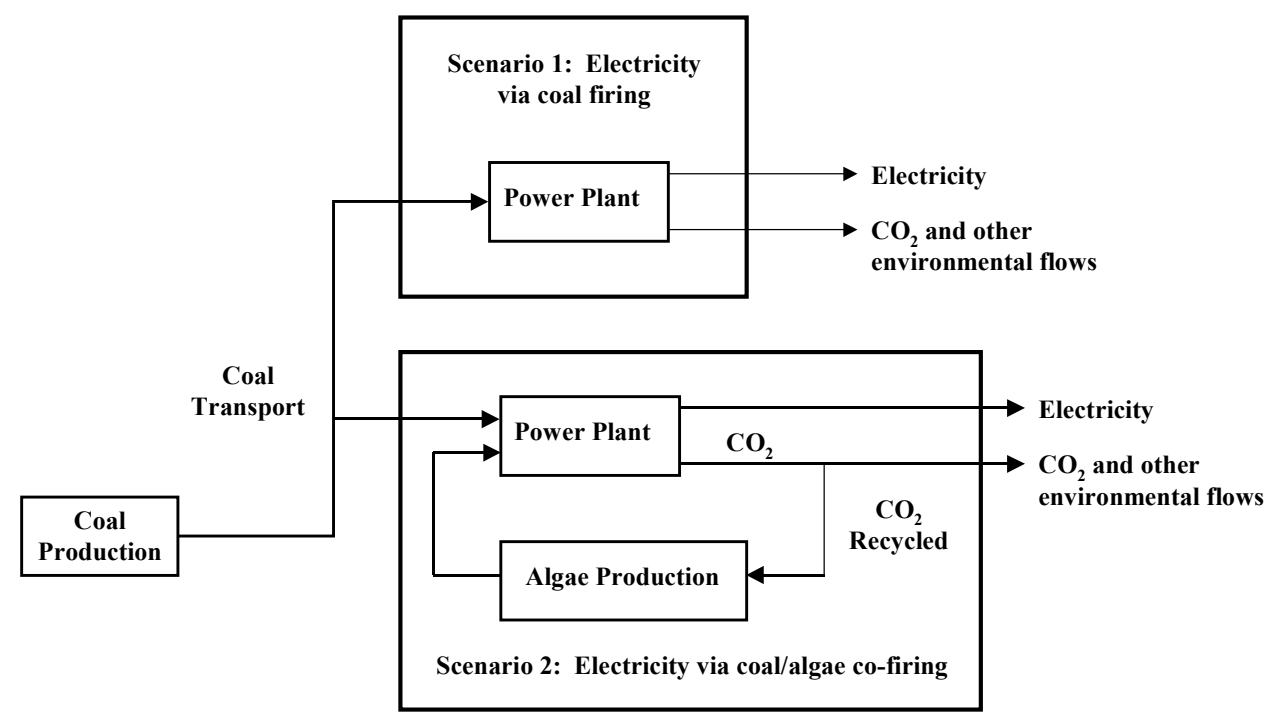

\section{Figure 3. General system boundaries for the comparison of electricity production via coal firing versus coal/algae cofiring.}

- Practical Reasons: An ever-expanding number of parameters can be tracked within an inventory, reflecting more comprehensive data measurements. For instance, including U.S. Toxic Release Inventory (TRI) data would result in a list of approximately 200 pollutants being released during gasoline production. Similarly, including radionucleide emissions from electricity production would result in tracking more than 150 specific flows. Therefore, managing such a large inventory list adds to the complexity of carrying out as well as interpreting the LCA because these additional flows should be collected for all sources within the system for the sake of consistency.

- More Fundamental Reasons: By restricting the inventory data collection to the information actually needed in a subsequent decision analysis, a more focused LCA can be carried out. This ensures that the issues at stake receive the highest priority and data quality. Some studies even restrict their data collection to pollutants contributing to a single effect, e.g., greenhouse gases.

Therefore, it is important to understand the issues or impacts that are of greatest concern to the users of the LCA (or decision-makers) and then tailor the data collection to meet their needs. It should be noted that an inventory number (e.g., quantity of lead) is only an indication of a potential impact. Additional data such as ambient concentration, pathways to human and ecological toxicity, and the existence of thresholds would be needed to assess the actual impact of this emission. These additional data are of the type required in risk assessment in which exposure data are collected for a few emissions at a single site. An actual LCA would need to gather these additional data for all inventory flows and for all sites included in the system boundaries (generally well over a hundred). Because the limitations of inventories are well known, this type of actual impact assessment is as difficult as it is impractical. 
LCA should consequently be considered as providing an indication of potential environmental impact, complementary to actual impacts evaluated by other tools. The following steps were used to facilitate interpretation of the inventory results through impact assessment:

- Classification: The organization of inventory data into environmental impact and resource consumption categories, such as global warming potential, acidification potential, natural resource depletion, etc.

- Characterization: Weighted summing of inventory data within each environmental impact category, based upon each flow's relative strength of potential influence upon the identified environmental impact or effect.

The characterization step explicitly takes into account the latest scientific assessments of the uncertainty inherent in the equivalency factors, such as global warming potentials. In addition, the discussion accompanying the characterization results clearly states that the results of a characterization analysis serve strictly to normalize the multiple flows within the LCI with respect to a particular environmental issue in terms of their relative strength of potential contribution to that issue. Characterization is not in any way intended to estimate the actual impact of the emissions upon environmental issues.

Furthermore, some of the inventory flows themselves may be highly uncertain, with an estimable magnitude of uncertainty. This uncertainty is appropriately combined with the uncertainty inherent in the equivalency factors used in the characterization step. Table 2 indicates the environmental inventory flows and their corresponding impact assessment categories considered in this study.

Some of these environmental flows can potentially have impacts on the environment that go beyond the effects caused by the flow itself. For this study, the potential impacts of the life-cycle flows were assessed for the following impact assessment indicators: greenhouse effect potential, natural resource depletion, acidification potential, and eutrophication potential.

To calculate the impact indicators, each flow that is determined to be a contributor to one of these categories is weighted according to its impact in comparison to a set baseline. For example, the baseline is grams of $\mathrm{CO}_{2}$ equivalent for the greenhouse effect potential indicator. The value for the flow is multiplied by this weighting factor to give an impact score for the particular flow. The impact scores for all contributing flows are then summed to give an overall impact score for the potential impact. The weighting of the environmental flows is based upon the best available scientific knowledge; however, the scores should be interpreted as potential impacts, not actual impacts. The exact methodology is discussed in more detail in Appendix B. 
Table 2. Environmental inventory flows considered in the study

\begin{tabular}{|c|c|}
\hline Environmental Flow & Associated Impact Category \\
\hline \multicolumn{2}{|l|}{ Natural Resources } \\
\hline Oil & Natural resources depletion 1 \\
\hline Coal & Natural resources depletion \\
\hline Natural Gas & Natural resources depletion \\
\hline $\begin{array}{l}\text { Other significant resources depending } \\
\text { on decision rules }\end{array}$ & Natural resources depletion \\
\hline \multicolumn{2}{|l|}{ Water Effluents } \\
\hline Chemical oxygen demand (COD) & Eutrophication potential \\
\hline Biological oxygen demand (BOD) & Eutrophication potential \\
\hline Nitrates & Eutrophication potential \\
\hline Phosphates & Eutrophication potential \\
\hline Total suspended solids & Direct use $^{\mathrm{a}}$ \\
\hline Metals & Direct use \\
\hline \multicolumn{2}{|l|}{ Air Emissions } \\
\hline $\mathrm{CO}_{2}$ & Greenhouse effect potential \\
\hline $\mathrm{CH}_{4}$ & Greenhouse effect potential \\
\hline $\mathrm{N}_{2} \mathrm{O}$ & Greenhouse effect potential \\
\hline $\mathrm{NO}_{\mathrm{x}}$ & Acidification potential \\
\hline $\mathrm{SO}_{\mathrm{x}}$ & Acidification potential \\
\hline Particulate & Direct use \\
\hline Hydrocarbons & Direct use \\
\hline $\mathrm{CO}$ & Direct use \\
\hline \multicolumn{2}{|l|}{ Solid Waste } \\
\hline Nonhazardous & Direct use \\
\hline Hazardous & Direct use \\
\hline \multicolumn{2}{|l|}{ Energy Use } \\
\hline Total primary energy & Direct use \\
\hline Process energy & Direct use \\
\hline Fossil fuel energy & Direct use \\
\hline
\end{tabular}

\subsubsection{Geographical Scope}

The focus of the project is the use of flue gas $\mathrm{CO}_{2}$ for producing algae and its use in electricity production in Southwestern United States. However, the geographic scope of particular data items is dictated by actual plant locations, feedstock origins, sources of electricity, etc.

\subsubsection{Algae Cofiring System}

The $\mathrm{CO}_{2}$ used for algae production originates in the Southwestern United States. The production of algae was assumed to occur in the vicinity of the power plant. However, for modeling purposes,

\footnotetext{
${ }^{1}$ Inflows such as sand, limestone, etc. could be used in the natural resources depletion index although their impact is negligible because of their natural abundance.
} 
U.S. average data are used. Data on ancillary materials needed for the conversion of $\mathrm{CO}_{2}$ to algae are based on a U.S. average situation. The combustion of the coal/algae blend was assumed to follow individual combustion emissions profiles of coal and algae.

\subsubsection{Electricity Production}

Electricity production was based on Ecobalance Inc.'s (Bethesda, Maryland) data for the United States using coal. This database was considered to be applicable to electricity production in the Southwestern United States. However, U.S. Department of Energy's data for nation-wide average $\mathrm{CO}_{2}$ emissions were used (USDOE 2000; Hong and Slatick 1994).

\subsubsection{Temporal Scope}

The issue here is whether to study a current situation, to model a future situation, or to model both current and future scenarios. Current and future scenarios could be quite different. For example, current scenarios would be limited to existing algae production technology. One reason for studying a mid- to long-term time frame, is that a widespread use of $\mathrm{CO}_{2}$ derived algae in the near-term is not probable. However, the results of this study are data-driven, and the use of forecast or modeled (rather than current, empirically based) production, conversion, and end-use technology parameters would greatly increase the uncertainty in the final results.

For this study, the latter part of the current decade has been selected as the production period.

\subsection{Product Parameters}

\subsubsection{Scenarios}

Coal firing to produce electricity and $\mathrm{CO}_{2}$ venting to the atmosphere is used as an existing scenario representing the status quo. Recycling $\mathrm{CO}_{2}$ to algae production and cofiring the algae with coal to produce electricity represents the alternative scenario.

\subsubsection{Functional Unit}

The functional unit of this study is the production of $1 \mathrm{MW}$ of electricity. The environmental burdens are calculated based on $1 \mathrm{MW}$ of electricity from either coal firing or coal/algae cofiring. Algae replace coal in the cofiring scenario on an energy-equivalent basis (using the lower heating value).

\subsection{Process Parameters}

Process parameters are strongly affected by the choices made on the project-related and productrelated parameters. For example, the assumption of technology bases using the latter part of the current decade justifies the targets for algae production. For the algae cofiring scenario, two algae production processes were evaluated: a direct injection process and an MEA-based process. Both processes assume algae dewatering to $50 \%$ solids using solar drying. 


\subsection{LCA-Specific Parameters}

\subsubsection{Allocation Rules}

In general, the overall production of desired products generates other products, which are recovered and used in other product systems. These are considered to be coproducts. The problem is the apportioning or allocating of energy resources, raw materials, pollutants, etc. from the production steps common to the product studied and the coproducts. Inputs and outputs of the common steps can be partitioned across the coproducts on various bases, including:

- Mass

- Dry mass

- Energy content

For this analysis, there were no main processes requiring allocation.

\subsection{Summary of Scoping Decisions and Approaches}

Table 3 summarizes the scoping decisions and approaches used in this project.

Table 3. Summary of scoping decisions and approaches

\begin{tabular}{|c|c|c|}
\hline Element & Parameter Type & Decision or Approach \\
\hline \multirow[t]{2}{*}{ Project } & Spatial & $\begin{array}{ll}\text { Algae production: } & \text { Southwestern United States } \\
\text { Electricity production: } & \text { United States } \\
\text { Electricity use: } & \text { Southwestern United States }\end{array}$ \\
\hline & Temporal & 2008 \\
\hline \multirow[t]{2}{*}{$\underline{\text { Product }}$} & $\mathrm{CO}_{2}$ & $\begin{array}{l}\text { Conversion to algae } \\
\text { Venting to the atmosphere (current disposal alternative) }\end{array}$ \\
\hline & Functional unit & Conversion of $\mathrm{CO}_{2}$ to algae to make $1 \mathrm{MW}$ electricity. \\
\hline \multirow[t]{2}{*}{$\underline{\text { Process }}$} & $\begin{array}{l}\text { Algae cultivation and } \\
\text { cofiring }\end{array}$ & $\begin{array}{ll}\text { Algae cultivation: } & \text { direct injection of } \mathrm{CO}_{2} \\
\text { Algae cultivation: } & \text { MEA extraction }\end{array}$ \\
\hline & Electricity & $\begin{array}{l}\text { Electricity production using coal for the United States } \\
\text { (average) }\end{array}$ \\
\hline$\underline{\mathrm{LCA}}$ & Interpretation & $\begin{array}{l}\text { Classification and characterization } \\
\text { Perform sensitivity analysis, if necessary, on uncertain or } \\
\text { variable input parameters }\end{array}$ \\
\hline
\end{tabular}




\section{LIFE CYCLE MODELING}

\subsection{LCA Software}

The TEAM $^{\mathrm{TM}}$ software (version 3.0) developed by Ecobalance Inc. was used in this analysis.

\section{2 $\mathrm{CO}_{2}$-to-Algae Processes}

The estimates of inputs and outputs for the two processes were developed using the technoeconomic model developed by Kadam and Sheehan (1996), with technology targets established for the latter part of the current decade. A simplified flow diagram is provided in Figure 4. The design basis for a 1000-hectare algal production system is shown in Table 4.

Table 4. Design parameters for algae cultivation

\begin{tabular}{|c|c|c|}
\hline & Parameter & Value \\
\hline \multicolumn{3}{|l|}{ Facility Parameters } \\
\hline Facility size & ha & 1000 \\
\hline Module size & ha & 20 \\
\hline Number of modules & & 43 \\
\hline Total $\mathrm{CO}_{2}$ processed & $\mathrm{mt} / \mathrm{yr}$ & 50419 \\
\hline Effective culture area fraction & & 0.86 \\
\hline \multicolumn{3}{|l|}{ Biological Parameters } \\
\hline Lipid content & wt. fr. dsb ${ }^{a}$ & 0.30 \\
\hline Protein content & wt. fr. dsb & 0.32 \\
\hline Carbohydrate content & wt. fr. dsb & 0.20 \\
\hline Ash content & wt. fr. dsb & 0.08 \\
\hline Intermediate content & wt. fr. dsb & 0.10 \\
\hline Solar radiation & $\mathrm{kcal} / \mathrm{m}^{2} / \mathrm{d}$ & 5000 \\
\hline Photosynthetic efficiency & $\%$ & 4.86 \\
\hline Salinity tolerance & $\mathrm{g} \mathrm{TDS} / \mathrm{L}^{\mathrm{b}}$ & 35 \\
\hline \multicolumn{3}{|l|}{ Operating Parameters } \\
\hline Operating season & $\mathrm{d} / \mathrm{yr}$ & 250 \\
\hline Cell concentration & $\mathrm{g} \mathrm{dcw} / \mathrm{L}$ & 0.8 \\
\hline Residence time & $\mathrm{d}$ & 7 \\
\hline Productivity & $\mathrm{g} / \mathrm{m}^{2} / \mathrm{d}$ & 17.1 \\
\hline Algal production, gross & $\mathrm{mt} / \mathrm{y}$ & 33171 \\
\hline Energy of algae produced & $10^{6} \mathrm{kcal} / \mathrm{yr}$ & 173481 \\
\hline \multicolumn{3}{|l|}{ Downstream Processing Parameters } \\
\hline Concentration factor, $1^{\text {st }}$ stage, microstrainers & & 10 \\
\hline \multicolumn{3}{|l|}{ Concentration factor, $2^{\text {nd }}$ stage, centrifuges } \\
\hline \multicolumn{3}{|l|}{ Concentration factor, overall } \\
\hline Harvest efficiency, overall & & 0.95 \\
\hline
\end{tabular}

${ }^{\mathrm{a}}$ Weight fraction on dry solids basis.

${ }^{\mathrm{b}}$ TDS: total dissolved solids. 


\subsubsection{Gas Delivery}

A blower is used to deliver $\mathrm{CO}_{2}$ to ponds in the direct injection process and to an absorber in the MEA process. The MEA process also requires a smaller blower to deliver purified $\mathrm{CO}_{2}$ gas to the ponds. Compressing $\mathrm{CO}_{2}$ to high enough pressures to transport it for a distance is energy intensive. For transportation and nighttime storage, the compression power required is an order of magnitude higher than that for a low-pressure blower. Hence, the pond system is assumed to be near the power plant.

\subsubsection{MEA Process}

A detailed flow diagram for the MEA process is given by Kadam (1997). In this process, the primary pieces of equipment are the absorber and stripper columns, together with the associated piping, heat exchange, and separation equipment. The inputs and outputs were calculated based on this model.

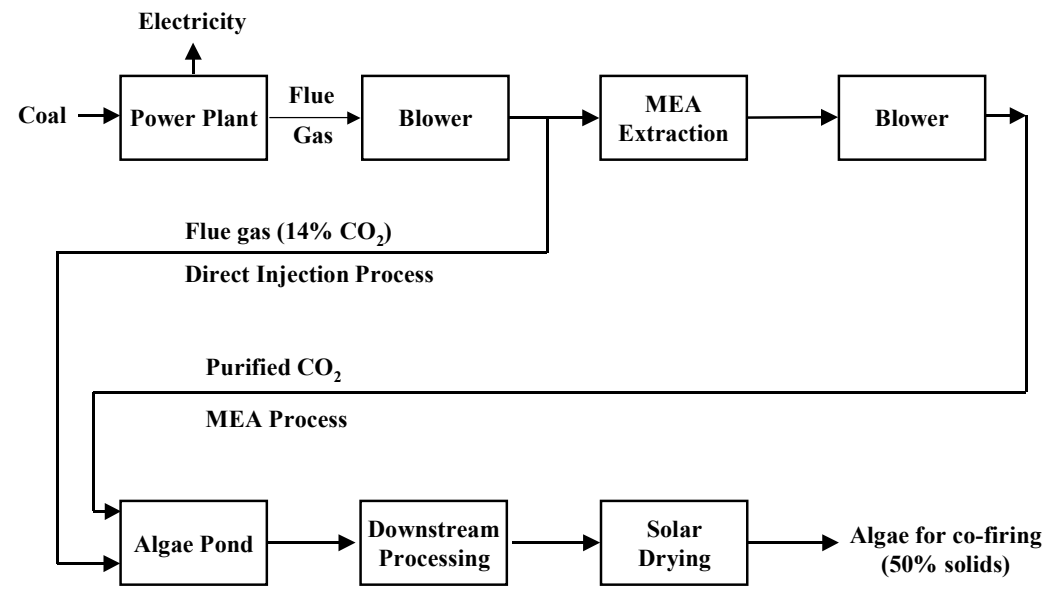

Figure 4. A simplified flow diagram for microalgae production.

\subsubsection{Algae Drying}

Algal drying is modeled after crop drying and dehydration practices. There is a vast experience with coffee production in Colombia using solar drying. Also, in northern Nicaragua hulled coffee is usually dried in the sun on drying floors or racks. Crop drying using the sun's energy is a centuriesold technique; however, modern solar-powered drying technologies brings new levels of costefficiency to the process of drying coffee, tea, cocoa, rice, corn, hay, tobacco, rubber, and a number of other crops, as well as for other agricultural dehydration processes (Brace Research Institute 1975).

Based on the agricultural experience with solar drying, it was assumed that solar drying of algae is feasible. Although a small amount of electricity may be needed for fans, no energy inputs for this step were included. The estimated power needed for fans, $5 \mathrm{kWh} / \mathrm{t} \mathrm{CO} 2,<5 \%$ of total electricity, is considered to be within the margin of error of the study. 


\subsubsection{Data Summary for $\mathrm{CO}_{2}$-to-Algae Processes}

Based on these design parameters, the following inputs and outputs for algae cultivation can be calculated. These estimates for a 1000-hectare algal production system, using $1 \mathrm{MW}$ as the basis, are reported in Table 5.

Table 5. Data summary for algae cultivation in a 1000-ha system

\begin{tabular}{lrr}
\hline & Per day & Per t $\mathbf{C O}_{2}$ \\
\hline INPUTS & & \\
Direct injection & & \\
$\mathrm{CO}_{2}, \mathrm{t}$ & 680.6 & 1 \\
Steam, kg & 0 & 0 \\
Electricity, kWh & 15,100 & 22.2 \\
MEA extraction & & \\
$\mathrm{CO}_{2}, \mathrm{t}$ & 680.6 & 1 \\
Steam, kg & $1,369,570$ & 2,010 \\
Electricity, kWh & 22,225 & 32.65 \\
Algae cultivation & & \\
$\mathrm{NH}_{3}, \mathrm{~kg}$ & 16.85 & 0.025 \\
Superphosphate, $\mathrm{kg}$ & 12.14 & 0.018 \\
Potassium sulfate, $\mathrm{kg}$ & 9.41 & 0.014 \\
$\mathrm{CO}_{2}, \mathrm{t}$ & 680.6 & 1 \\
Steam, kg & 0 & 0 \\
Electricity, kWh & 56,280 & 82.7 \\
Algae drying & & \\
Solar drying & & \\
Steam, kg & 0 & 0 \\
Steam drying & & \\
\hline Steam, kg & & \\
OUTPUTS & & \\
CO & , kg \\
Algae - dry, kg & $1,615,584$ & 2,374 \\
Algae - wet, kg & & \\
Energy of dry algae, MJ & $8.12 \times 10^{6}$ & 11,927 \\
\hline
\end{tabular}

A 1000-ha algae cultivation system can process roughly $250,000 \mathrm{t} / \mathrm{yr}$ of $\mathrm{CO}_{2}$. A $50 \mathrm{MW}$ plant generates $414,000 \mathrm{t} / \mathrm{yr}$ of $\mathrm{CO}_{2}$, which means that the 1000 -ha system can use approximately $60 \%$ of the emitted $\mathrm{CO}_{2}$. Results are provided for different levels of $\mathrm{CO}_{2}$ recycling. However, as no compression system is assumed in the current scheme, no night storage is possible, and recycling $50 \%$ of the emitted $\mathrm{CO}_{2}$ is assumed to be the feasible approach. 


\subsection{Electricity Production}

The general electricity grid model includes the following:

- Pre-combustion processes: coal mining (surface and underground) and transportation; natural gas extraction and transportation; crude oil extraction (off-shore and on-shore), refining, and transportation; production of nuclear fuel ( $\mathrm{UF}_{6}$ accumulation and fuel rod manufacturing), and hydroelectric power production

- Combustion in power plants

- Distribution (losses: 7.7\%)

An average situation for coal-based electricity production modeled by Ecobalance Inc. was used.

There is information available for biomass cofiring in general (Hughes 2000; Tillman, 2000a; Tillman, 2000b), however, not specifically for algae cofiring. Hence, for electricity production using algae cofiring, $\mathrm{CO}_{2}$ and $\mathrm{NO}_{\mathrm{x}}$ combustion-related emissions attributable to the algae were based on their carbon ( $56 \%$ on a dry solid basis) and nitrogen ( $4 \%$ on a dry solid basis) contents. About $1 \%$ of the carbon was assumed to be released as CO. Electricity production from algae was assumed at 33\% efficiency and was based on the net energy available after evaporating the water. Electricity production from algae depended on the extent of $\mathrm{CO}_{2}$ recycle; the remainder was from coal.

\subsection{Steam Production}

The energy necessary to convert water to steam is based on the enthalpy of the steam $(2.6 \mathrm{MJ} / \mathrm{kg}$ at approximately $150 \mathrm{psi}$ and $350^{\circ} \mathrm{F}$ ) and a boiler efficiency of $80 \%$. Steam is assumed to be produced by combusting fuel in industrial boilers. The fuel can consist of coal, natural gas or heavy fuel oil.

The assumed heating values of the three fuels are as follows:

- Natural Gas - $52 \mathrm{MJ} / \mathrm{kg}$

- Heavy Fuel Oil - $42 \mathrm{MJ} / \mathrm{kg}$

- Coal $-29.3 \mathrm{MJ} / \mathrm{kg}$

The emission factors for industrial boilers were obtained from the AP-42 report by the EPA (EPA 1995b). These numbers were compared with a study done by the Argonne National Laboratory (Wang 1996), to verify and expand on the EPA emission factors.

Specifically, a coal-fired boiler was modeled in this study. All the factors reported are for uncontrolled emissions. If control technologies are used, the emission factors should be reduced by the efficiencies of the control devices. Emission factors for heavy fuel oil and natural gas production are outlined by Kadam et al. (1999). 


\section{$5.5 \quad \mathrm{CO}_{2}$ Accounting}

For this study, it is assumed that $\mathrm{CO}_{2}$ released during algae cofiring is recycled and is reused by the algae (see Figure 3). Thus, the net $\mathrm{CO}_{2}$ balance for growing and burning of algae is zero. Therefore, algae-derived $\mathrm{CO}_{2}$ is not used in the impact assessment phase to calculate greenhouse gas potential. During algae cultivation, however, some fossil energy is consumed, and the resultant fossil $\mathrm{CO}_{2}$ is charged to the algae scenario as a burden.

\section{DATA QUALITY AND SOURCES}

For an LCA, there are two different types of data: primary and secondary (SETAC 1993). Primary data are obtained directly from individual production plants or companies. Secondary data are published sources such as databases, industry or government publications, journals, or books. Another kind of secondary data includes "educated guesses," or data coming from experts based on their knowledge in the field, but not published.

In general, the goals for data collection, quality, and utilization are to use the most recent data available that are representative of an industry or practice. The specific goals for this study were to obtain data on the processes leading to the conversion of $\mathrm{CO}_{2}$ into algal mass and its cofiring with coal to produce electricity.

\subsection{Data Sources}

Details of the data used in the analysis are summarized in Table 5.

\subsection{Data Quality}

Data in an LCA should have indicators for reliability and completeness. The "reliability indicator" pertains to how data were obtained and verified, independent of the data quality goals outlined in the study. The "completeness indicator" pertains to how representative the data samples are, i.e., do the data represent an adequate sample size, and do the data cover an adequate period such that normal fluctuations are evened out? The completeness indicator is also treated as independent of the data quality goals outlined in the study. Currently, actual data indicators have not been established in LCA guidelines. Instead, a table is generally provided to indicate the type of data in each life cycle sector and the reliability and completeness for each. Table 6 provides the general data categories in this study and provides a description of each. In addition, Table 6 lists the sources and whether they are primary or secondary, a "checklist" of the reliability criteria, the geographical and temporal extent of the data, and limitations. 
Table 6. Data sources and quality

\begin{tabular}{|c|c|c|c|c|}
\hline $\begin{array}{c}\text { Data } \\
\text { Category }\end{array}$ & Description & $\begin{array}{l}\text { Source Type } \\
\text { and Date }\end{array}$ & $\begin{array}{c}\text { Geographic } \\
\text { and Temporal } \\
\text { Representation }\end{array}$ & $\begin{array}{c}\text { Reliability and } \\
\text { Completeness }\end{array}$ \\
\hline $\begin{array}{l}\text { Algae } \\
\text { production }\end{array}$ & $\begin{array}{l}\text { Materials, } \\
\text { energy, } \\
\text { emissions }\end{array}$ & $\begin{array}{l}\text { Primary; NREL } \\
\text { (1999) }\end{array}$ & $\begin{array}{l}\text { U.S. } \\
1990 \mathrm{~s}\end{array}$ & $\begin{array}{l}\text { Reliable and complete } \\
\text { (based on bench-scale data } \\
\text { and process modeling) }\end{array}$ \\
\hline $\begin{array}{l}\text { Electricity } \\
\text { production }\end{array}$ & $\begin{array}{l}\text { Materials, } \\
\text { energy, } \\
\text { emissions }\end{array}$ & Secondary & $\begin{array}{l}\text { U.S. } \\
1990 \mathrm{~s}\end{array}$ & Reliable and complete \\
\hline $\begin{array}{l}\text { Steam } \\
\text { production }\end{array}$ & $\begin{array}{l}\text { Materials, } \\
\text { energy, } \\
\text { emissions }\end{array}$ & $\begin{array}{l}\text { Secondary; U.S. } \\
\text { EPA AP-42 } \\
\text { (1997) }\end{array}$ & $\begin{array}{l}\text { U.S. } \\
\text { 1980s, 1990s }\end{array}$ & Reliable and complete \\
\hline $\begin{array}{l}\text { Algae } \\
\text { cofiring }\end{array}$ & $\begin{array}{l}\text { Materials, } \\
\text { energy, } \\
\text { emissions }\end{array}$ & N/A & & $\begin{array}{l}\text { Energy values: Reliable and } \\
\text { complete } \\
\text { Emissions: Assumed but } \\
\text { considered to be a reliable } \\
\text { approximation }\end{array}$ \\
\hline
\end{tabular}

\section{RESULTS AND DISCUSSION}

\subsection{Presentation of Results}

The results are presented for the two different scenarios: 1) venting of $\mathrm{CO}_{2}$ and coal firing (status $q u o$ ) and 2) converting $\mathrm{CO}_{2}$ to algae and its cofiring. As mentioned earlier, the basis chosen for the comparison of the two different disposal options is $1 \mathrm{MW}$ of electricity. In addition to actual flows, percentage differences are also included, which indicate the degree to which the values for the algae cofiring scenario (Scenario 2) were different from those for the status quo scenario (Scenario 1). A positive value indicates the percentage by which the values for the algae cofiring scenario were lower than those for the coal-firing scenario, and vice versa.

$$
\% \text { Difference }=\frac{\text { Scenario } 1 \text { value }- \text { Scenario } 2 \text { value }}{\text { Scenario } 1 \text { value }} \times 100
$$

\subsection{Time-Space Implications of Emissions}

It should be noted that this report shows the life-cycle emissions of the two options without considering the spatial and temporal attributes, meaning that the results are aggregated over different locations and different time frames. This report only shows the difference in the total emissions of the two options and does not account for concentrations of pollutants at a given time. 


\subsection{Life Cycle Energy Balance}

The energy use of the competing scenarios is one measure of their overall environmental performance. LCIs provide an opportunity to quantify both the total energy demands and the overall energy efficiencies of processes and products. In this study, several different types of energy flows are tracked through each life cycle. For clarity, each of these energy flows is defined below.

- Total Primary Energy. All raw materials extracted from the environment can contain ${ }^{2}$ energy. In estimating the total primary energy inputs to each life cycle, the cumulative energy content of all resources extracted from the environment is considered.

- Feedstock Energy. Energy contained in raw materials that end up directly in the final product is termed "feedstock energy." Feedstock energy is a subset of primary energy inputs.

- Process Energy. The second major subset of primary energy is "process energy." This is limited to energy inputs in the life cycle exclusive of the energy contained in the feedstock (as defined in the previous bullet). It is the energy contained in raw materials extracted from the environment that does not contribute to the energy of the product itself, but is needed to process feedstock energy into its final product form. Process energy is primarily generated from coal, natural gas, uranium, and hydroelectric power consumed directly or indirectly in the product life cycle.

- Fossil or Nonrenewable Energy. The primary energy that comes from fossil sources specifically (coal, oil, and natural gas) is tracked because it is important to distinguish between fossil and non-fossil energy. All three of the previously defined energy flows can be categorized as either fossil or non-fossil energy.

- Renewable Energy. Renewable energy refers to energy obtained from algae and also to electricity production from renewable sources such as biomass and hydroelectricity.

In the summary tables, the following energy values are reported: 1) feedstock energy, 2) fossil or nonrenewable energy, 3) renewable energy, 4) process energy, and 5) total primary energy. Criteria air pollutants are linked to the use of both nonrenewable and renewable energy, whereas natural resource depletion ${ }^{3}$ and fossil $\mathrm{CO}_{2}$ emissions are only linked to nonrenewable sources. Renewable energy use in Scenario 1 refers to renewable resources used to produce a portion of electricity used. Process energy indicates the net energy input to the process and can be useful in comparing process options.

\footnotetext{
2 The energy "contained" in a raw material is the amount of energy that would be released by the complete combustion of that raw material. This "heat of combustion" can be measured in two different ways: as a higher heating value or a lower heating value. Combustion results in the formation of $\mathrm{CO}_{2}$ and water. Higher heating values consider the amount of energy released when the final combustion products are gaseous carbon dioxide and liquid water. Lower heating values take into account the loss of energy associated with the vaporization of the liquid water combustion product. The energy content used is based on the lower heating values for each material.

3 Soil erosion is not included in the calculation of natural resource depletion because data were not available. The effects of biomass harvesting on soil erosion are more difficult to quantify than the removal of other natural resources, e.g., coal and oil.
} 


\subsection{LCI for Coal Firing versus Coal/Algae Cofiring: Direct Injection Process}

A comparison of environmental flows for Scenario 2 versus Scenario 1 for the direct injection process (using solar drying) is presented in Table 7 . Table 7 lists results for $100 \%, 75 \%, 50 \%$, and $25 \% \mathrm{CO}_{2}$ recycle, and Figures 5 through 18 provide results in graphical form for $100 \%$ and $50 \%$ $\mathrm{CO}_{2}$ recycle. However, $50 \% \mathrm{CO}_{2}$ recycle is the most feasible, and the following discussion is limited to this option.

\subsubsection{Resource Depletion}

Depletion of non-renewable resources, such as coal, crude oil, and natural gas, is an important sustainability criterion. Coal usage is significantly lower but natural gas and oil usage are higher for Scenario 2. The reason that natural gas usage is higher for Scenario 2 is because of the ammonia and super phosphate use during algae production, which is absent in Scenario 1. Super phosphate production also consumes a fair amount of crude oil. Thus, the algae option offsets coal consumption but other non-renewable resources are consumed in its production. The relative importance of depleting these non-renewable resources is also captured in impact assessment (see section 7.7).

\subsubsection{Air Pollutants}

Carbon monoxide and hydrocarbons (except methane) emissions for Scenario 2 are somewhat higher, by $6 \%-8 \%$, than those for Scenario 1 . This increase can be considered as not significant as it falls within the margin of error for the analysis. However, this increase results from the higher natural gas and ammonia consumption for Scenario 2 (see Table 8). Particulate emissions (PM10 and unspecified), $\mathrm{SO}_{\mathrm{x}}$, and $\mathrm{NO}_{\mathrm{x}}$ are lower for Scenario 2 by $39 \%$ each. Coal production and electricity from coal both result in higher particulates, $\mathrm{SO}_{\mathrm{x}}$, and $\mathrm{NO}_{\mathrm{x}}$ emissions. These three emissions are lower for Scenario 2 because it partly displaces coal production and electricity from coal.

\subsubsection{Waste Generation}

In case of liquid phase wastes, COD values are significantly higher for Scenario 2. This is a result of high COD values attributable to fertilizer production. However, these water emissions do not occur during the actual process, but rather during upstream production of raw materials used in the process, e.g., ammonia, super phosphate, potassium sulfate, etc. As shown in Table 8, COD values are especially high for ammonia, which is used only in Scenario 2. Total solid waste values are slightly lower for Scenario 2 than those for Scenario 1. These can be attributed to much lower coal requirements for Scenario 2.

\subsubsection{Energy Consumption and GHGs}

Process energy requirements are comparable for both the scenarios. This means that the energy input to the algae production step is comparable to that of the coal production step. However, the nature of the energy consumed is different. Nonrenewable energy consumption is $34 \%$ lower for Scenario 2 than for Scenario 1, and as expected, the renewable energy consumption is very high for Scenario 2 and very low for Scenario 1 . Emissions are lower by $30-40 \%$ for $\mathrm{CO}_{2}, \mathrm{~N}_{2} \mathrm{O}$, and $\mathrm{CH}_{4}$, which are key GHGs. This is due to the high emissions of these gases during coal production and electricity generation from coal (Table 9). 
Table 7. Life cycle inventory for coal firing versus coal/algae cofiring: Direct injection process (solar drying)

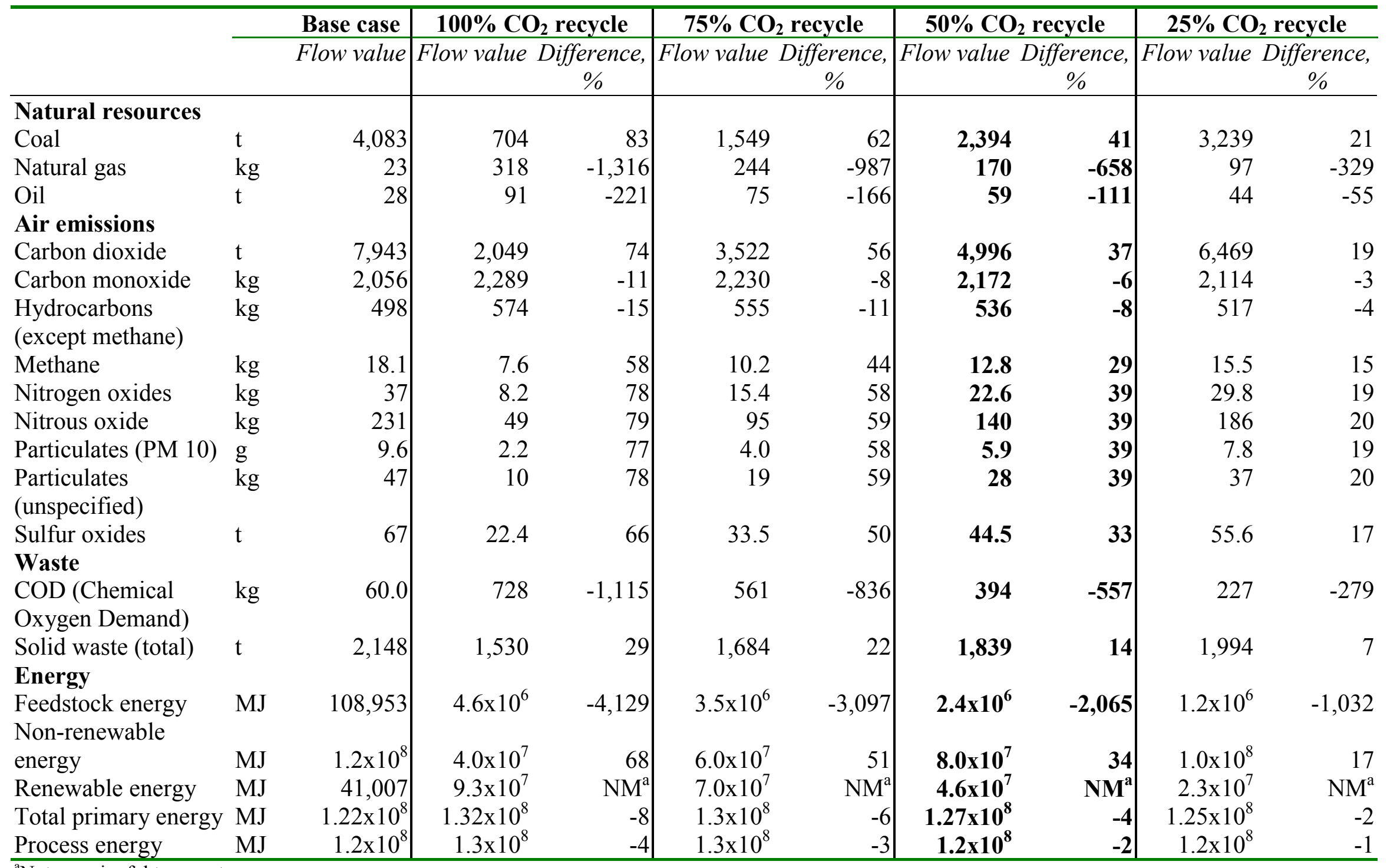

${ }^{a}$ Not meaningful to report. 


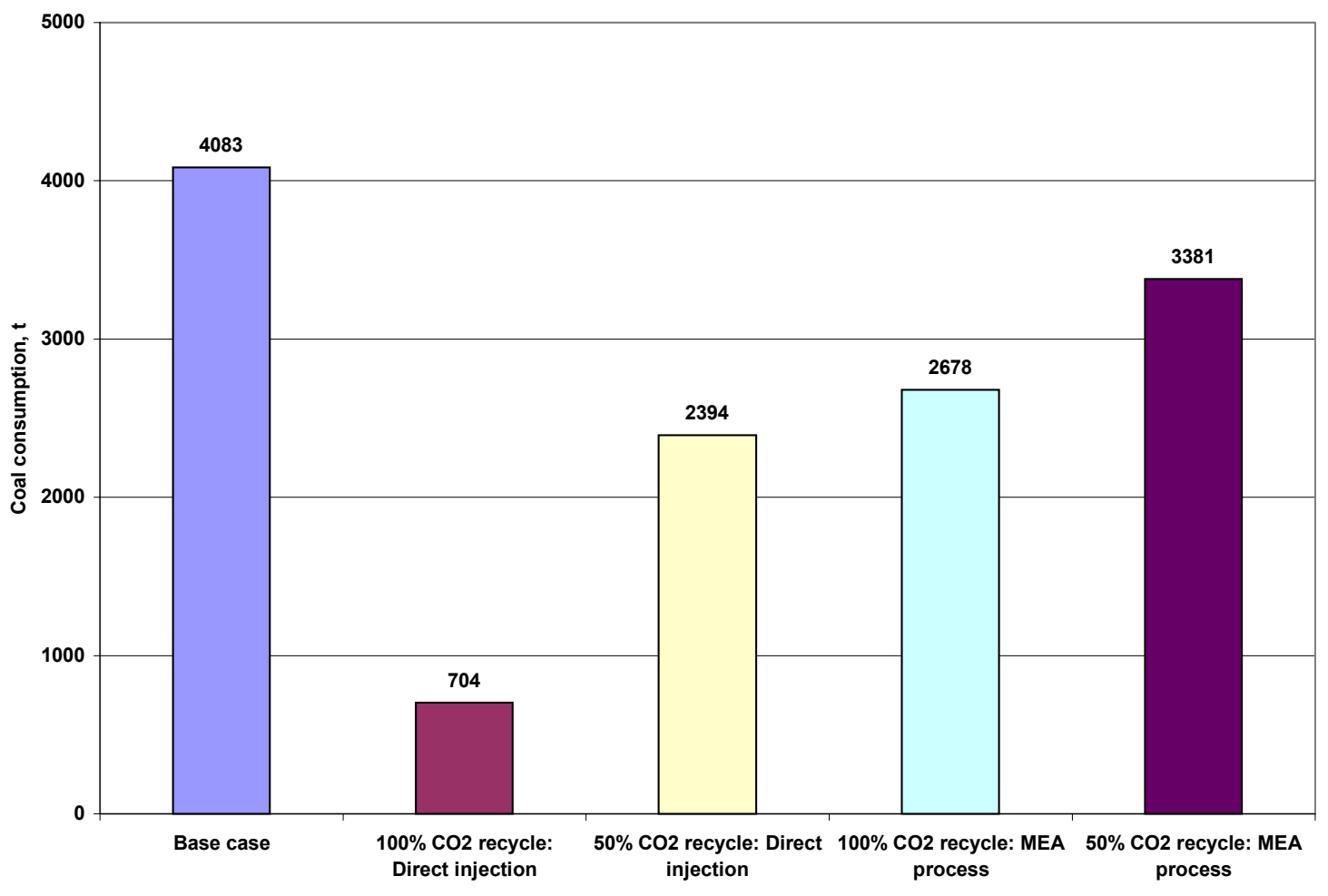

Figure 5. Coal usage for coal firing versus coal/algae cofiring.

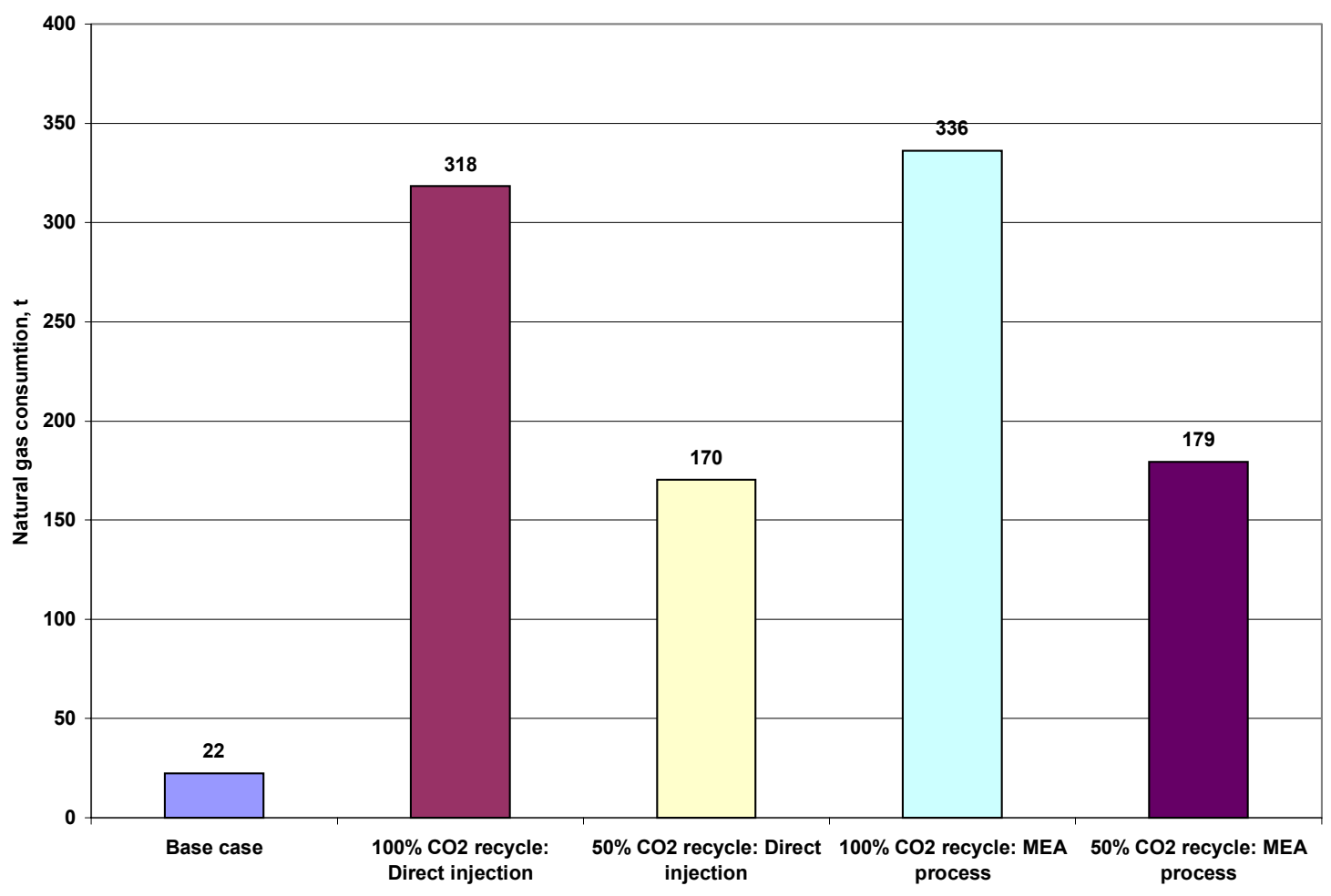

Figure 6. Natural gas usage for coal firing versus coal/algae cofiring. 


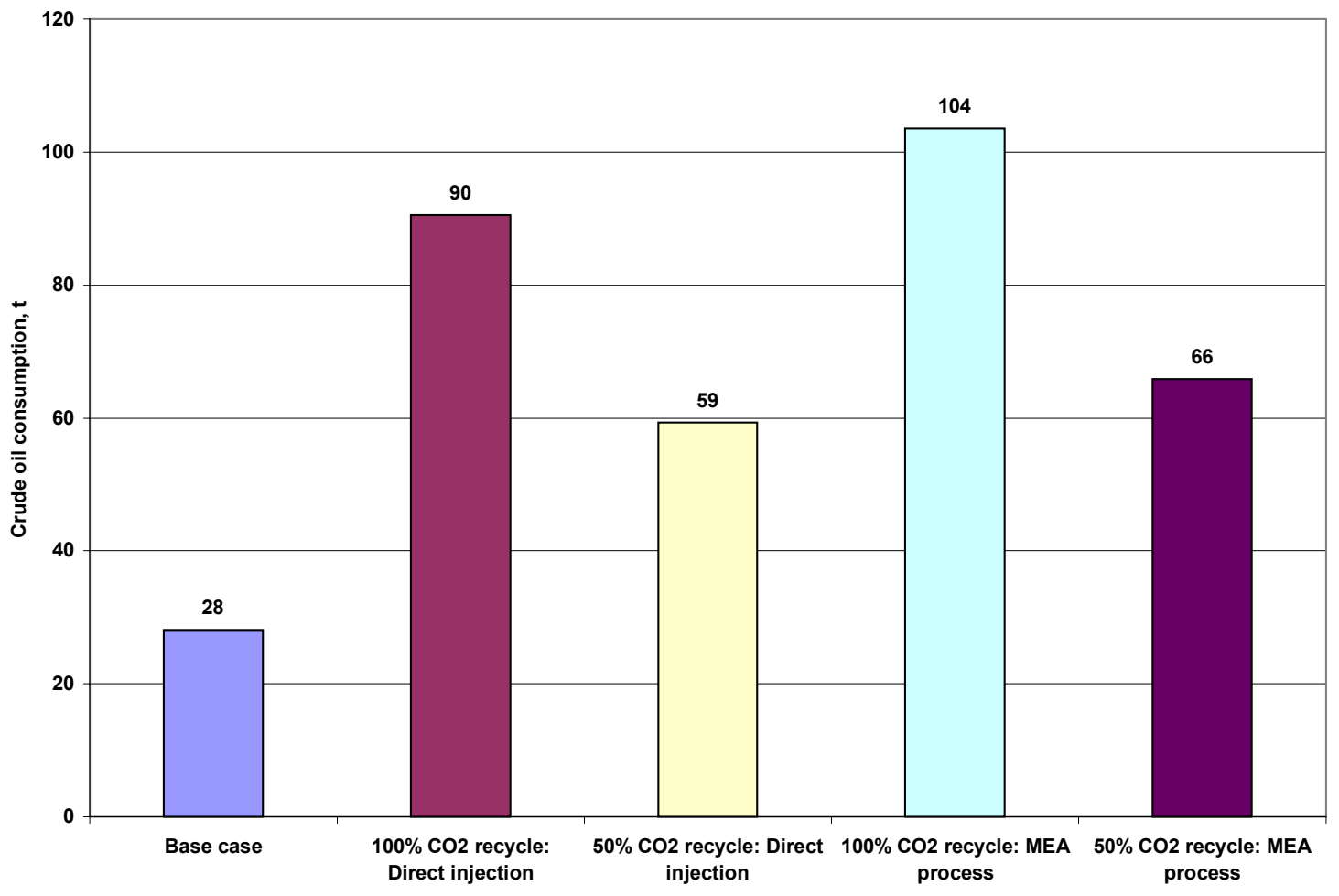

Figure 7. Crude oil usage for coal firing versus coal/algae cofiring.

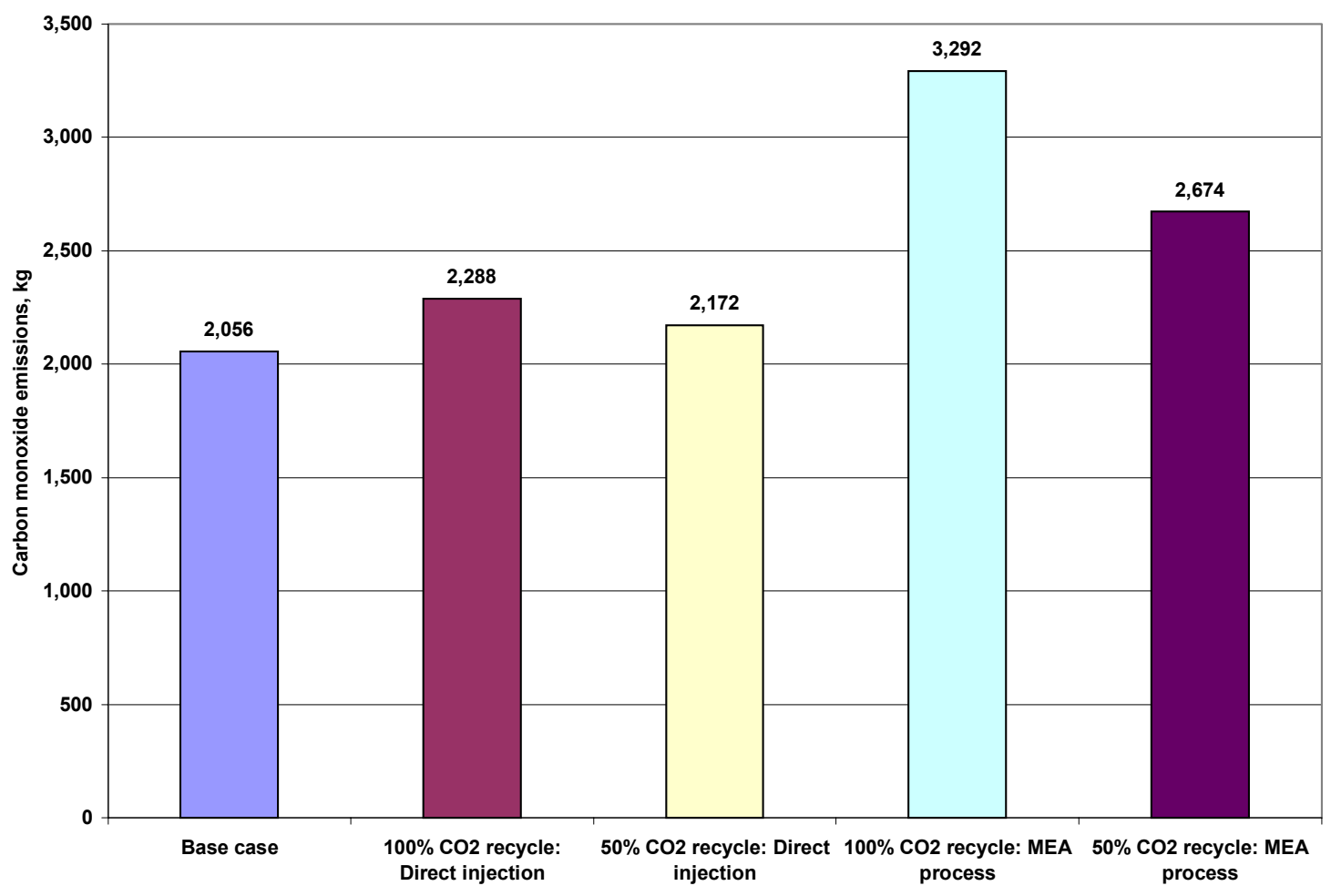

Figure 8. Carbon monoxide emissions for coal firing versus coal/algae cofiring. 


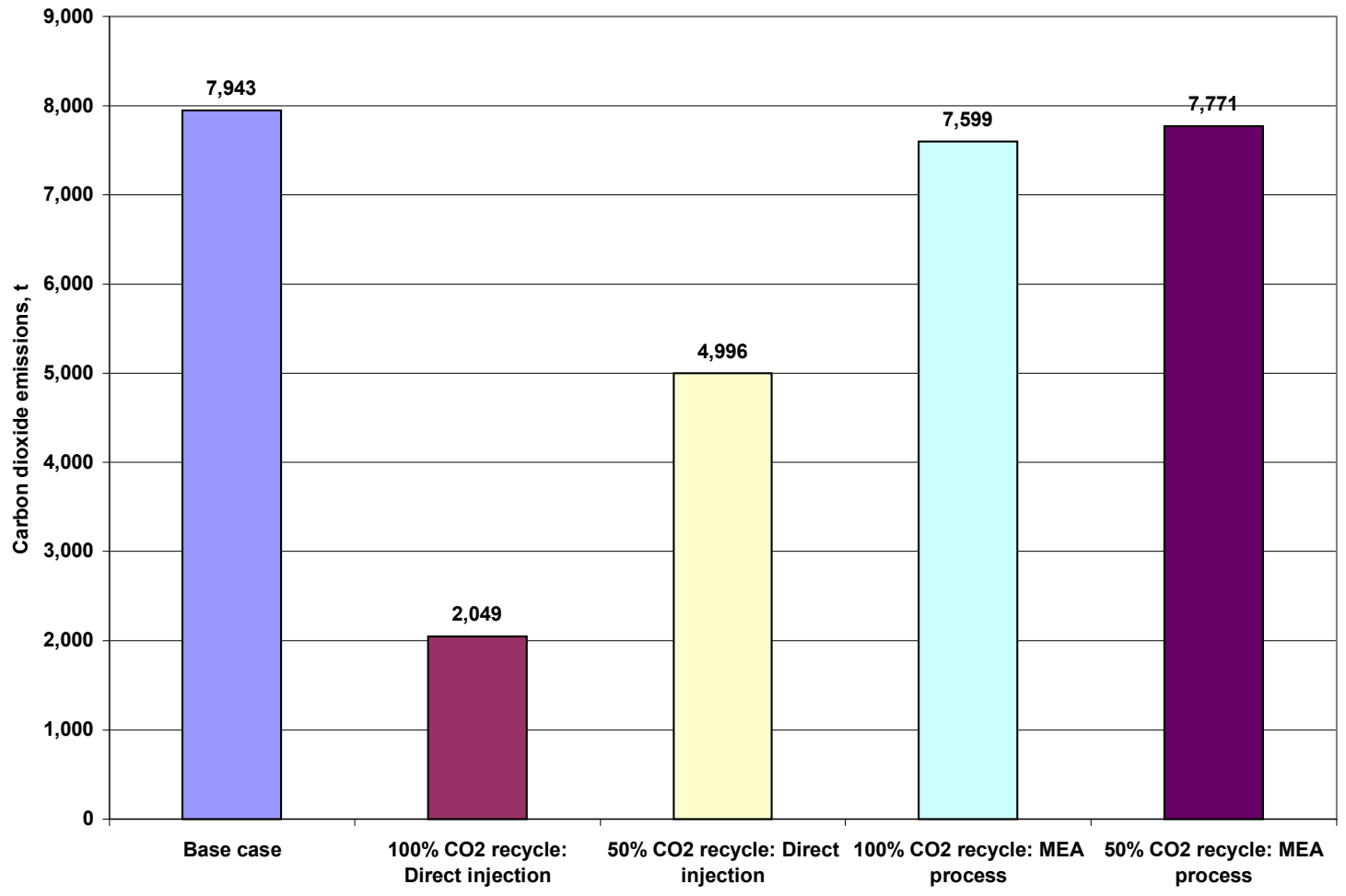

Figure 9. Fossil $\mathrm{CO}_{2}$ emissions for coal firing versus coal/algae cofiring.

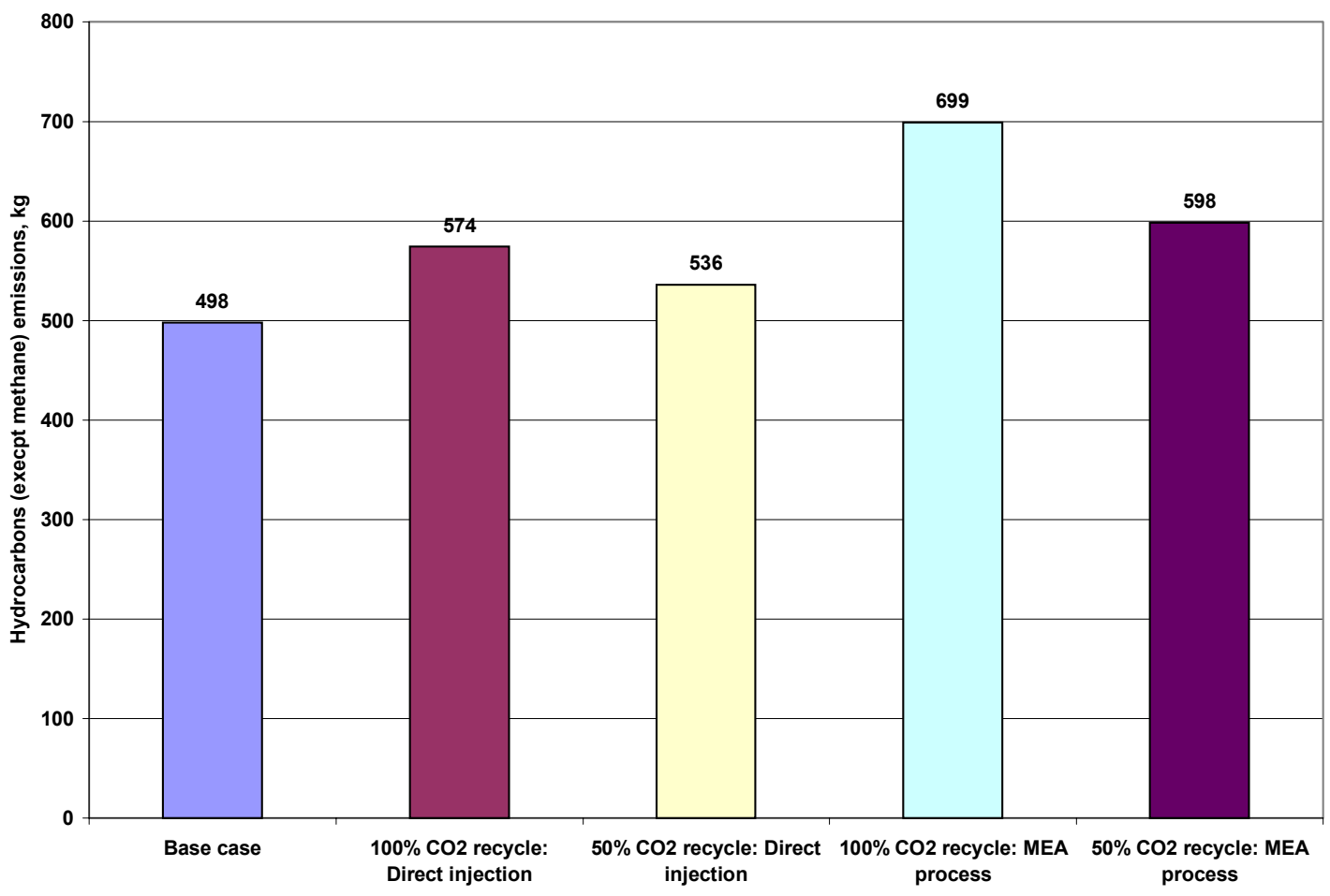

Figure 10. Hydrocarbon (except methane) emissions for coal firing versus coal/algae cofiring. 


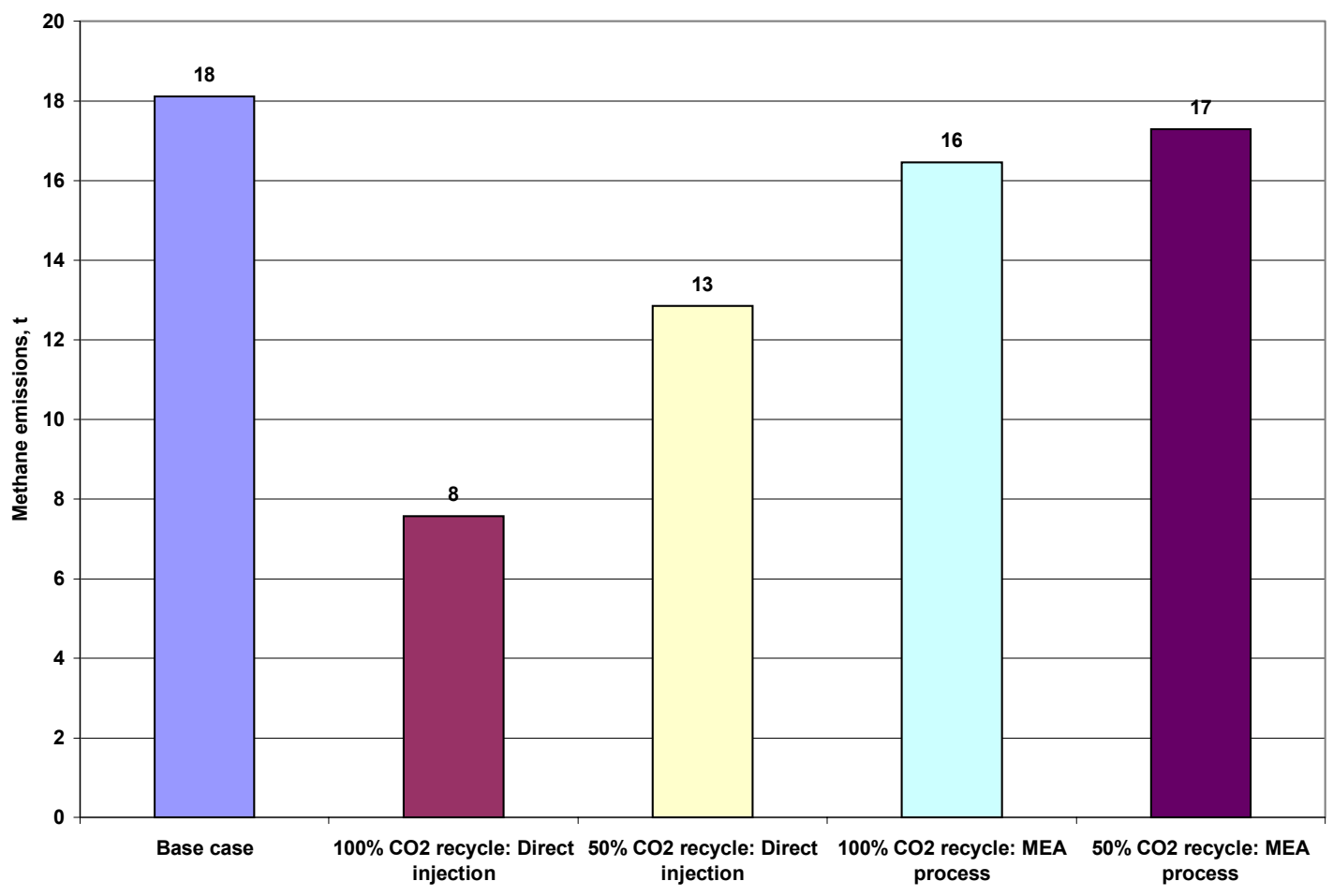

Figure 11. Methane emissions for coal firing versus coal/algae cofiring.

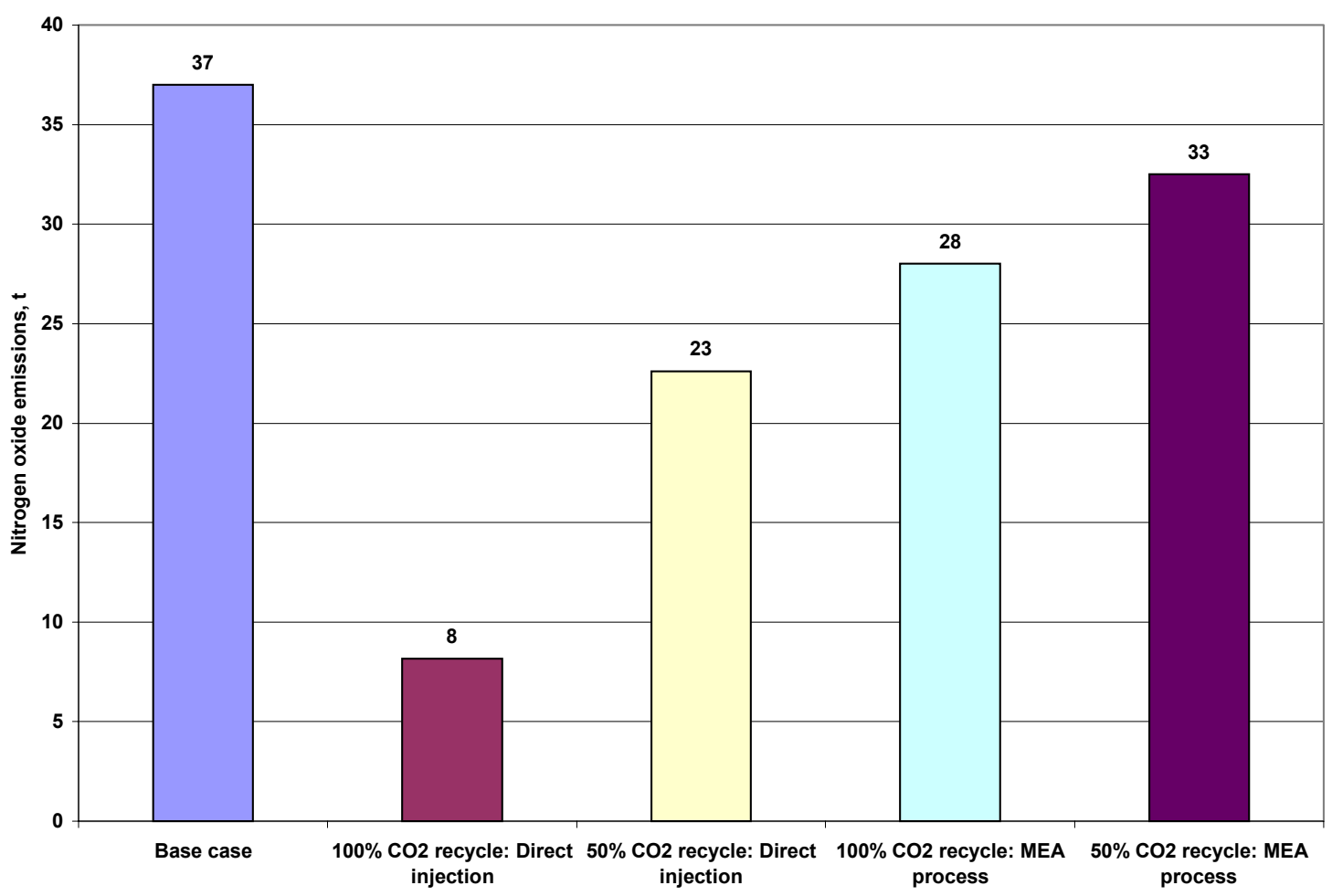

Figure 12. Nitrogen oxides $\left(\mathrm{NO}_{\mathrm{x}}\right.$ as $\left.\mathrm{NO}_{2}\right)$ emissions for coal firing versus coal/algae cofiring. 


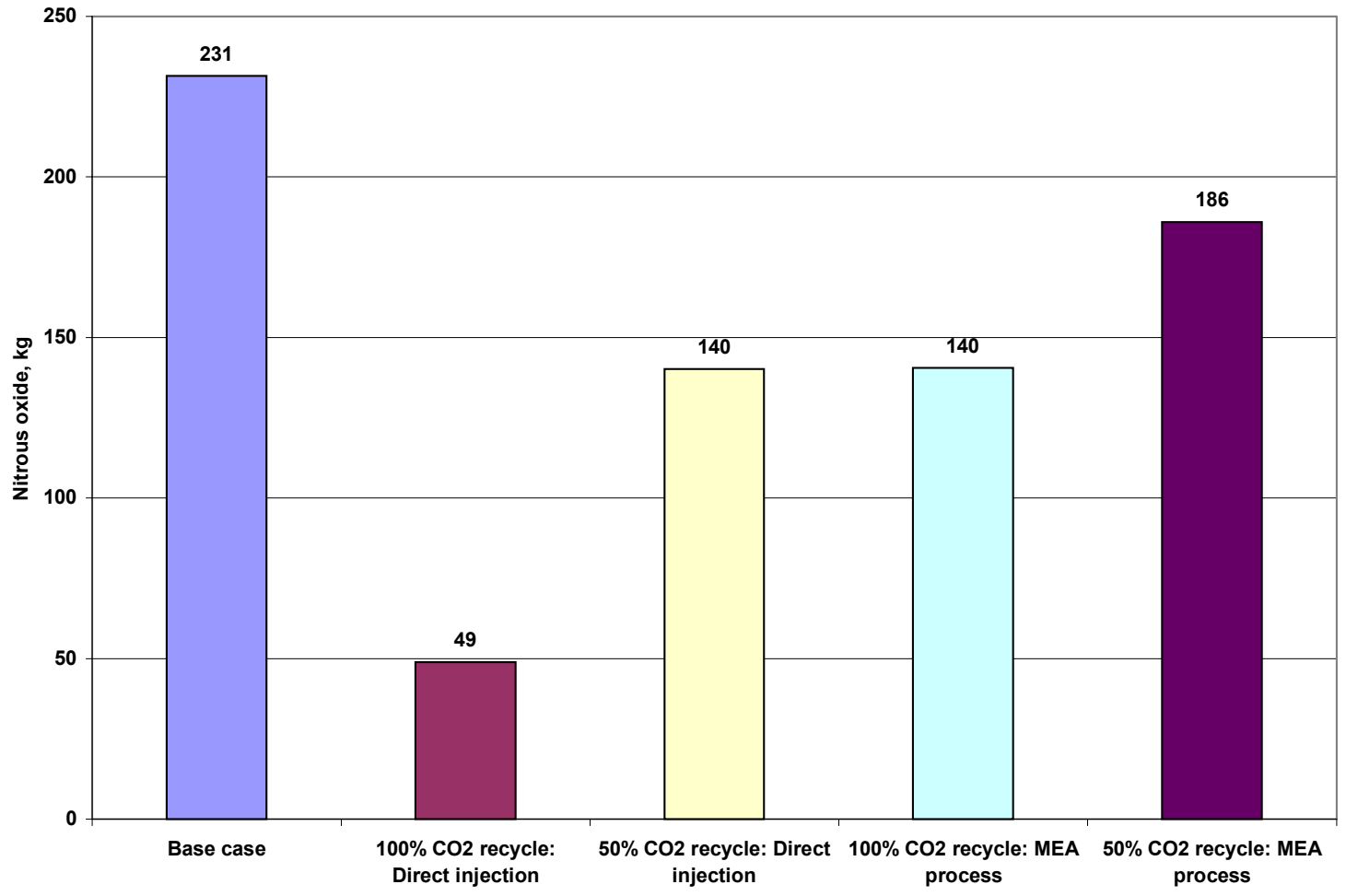

Figure 13. Nitrous oxide emissions for coal firing versus coal/algae cofiring.

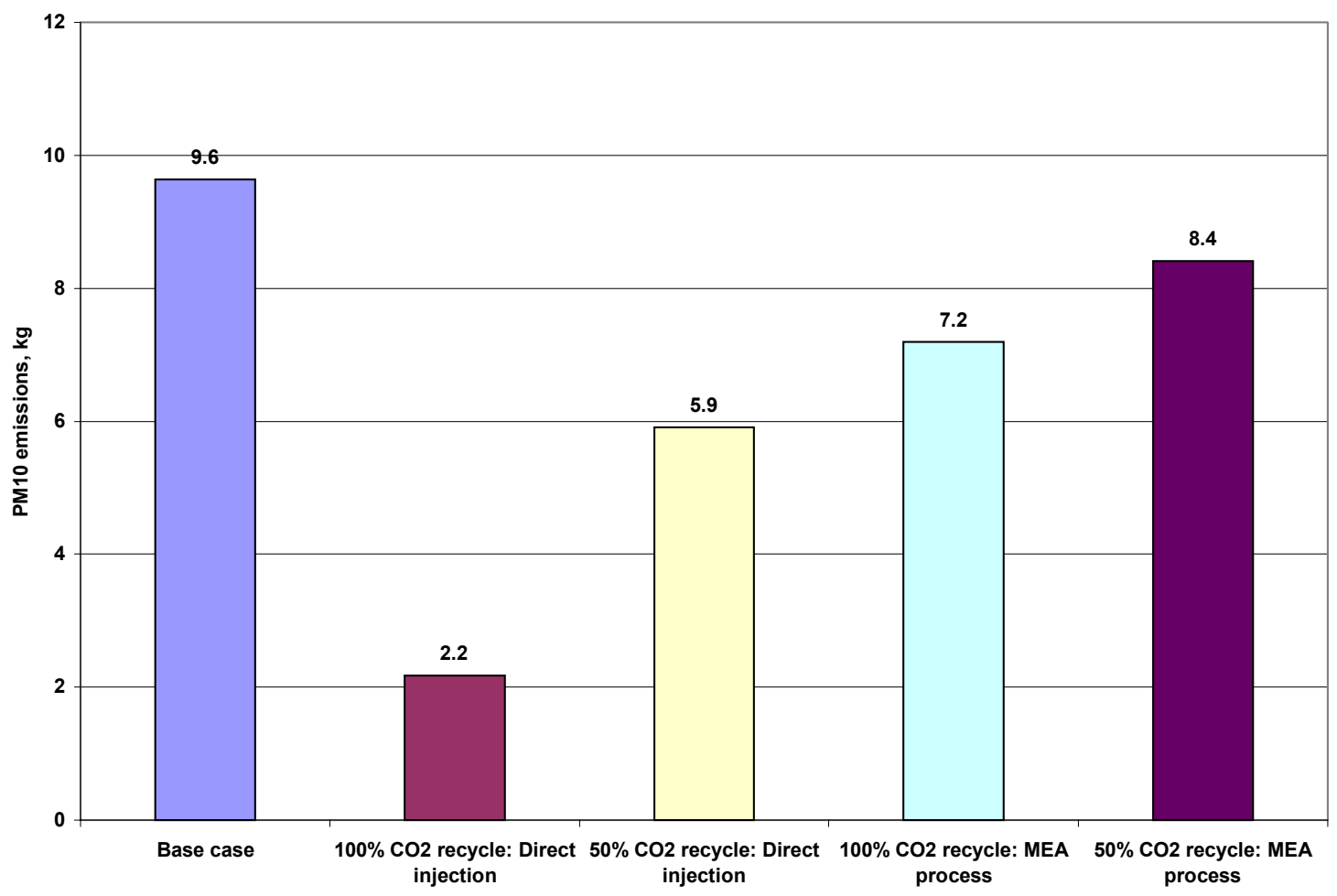

Figure 14. PM10 emissions for coal firing versus coal/algae cofiring. 


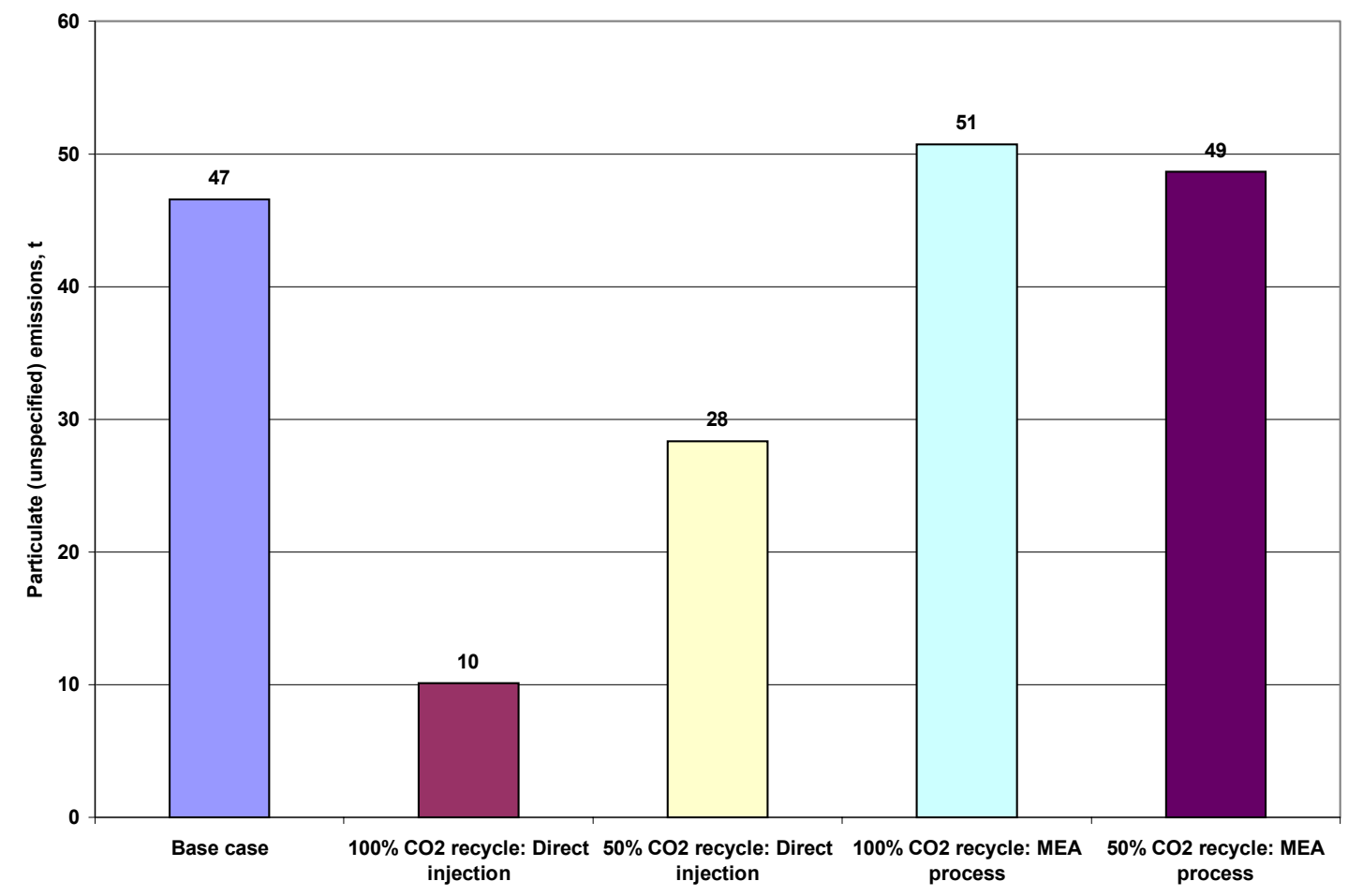

Figure 15. Particulate matter (unspecified) emissions for coal firing versus coal/algae cofiring.

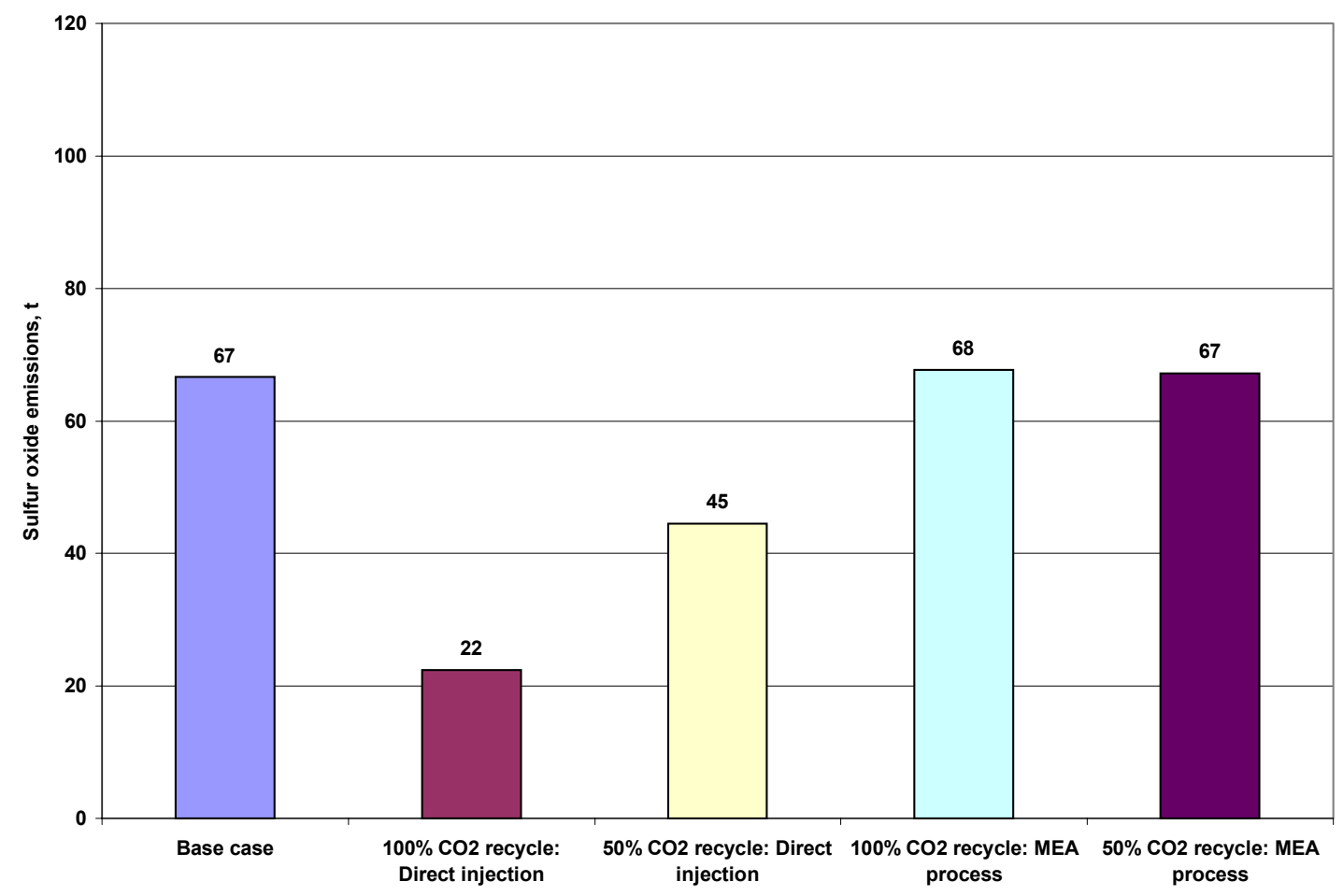

Figure 16. Sulfur oxides ( $\mathrm{SO}_{\mathrm{x}}$ as $\left.\mathrm{SO}_{2}\right)$ emissions for coal firing versus coal/algae cofiring. 


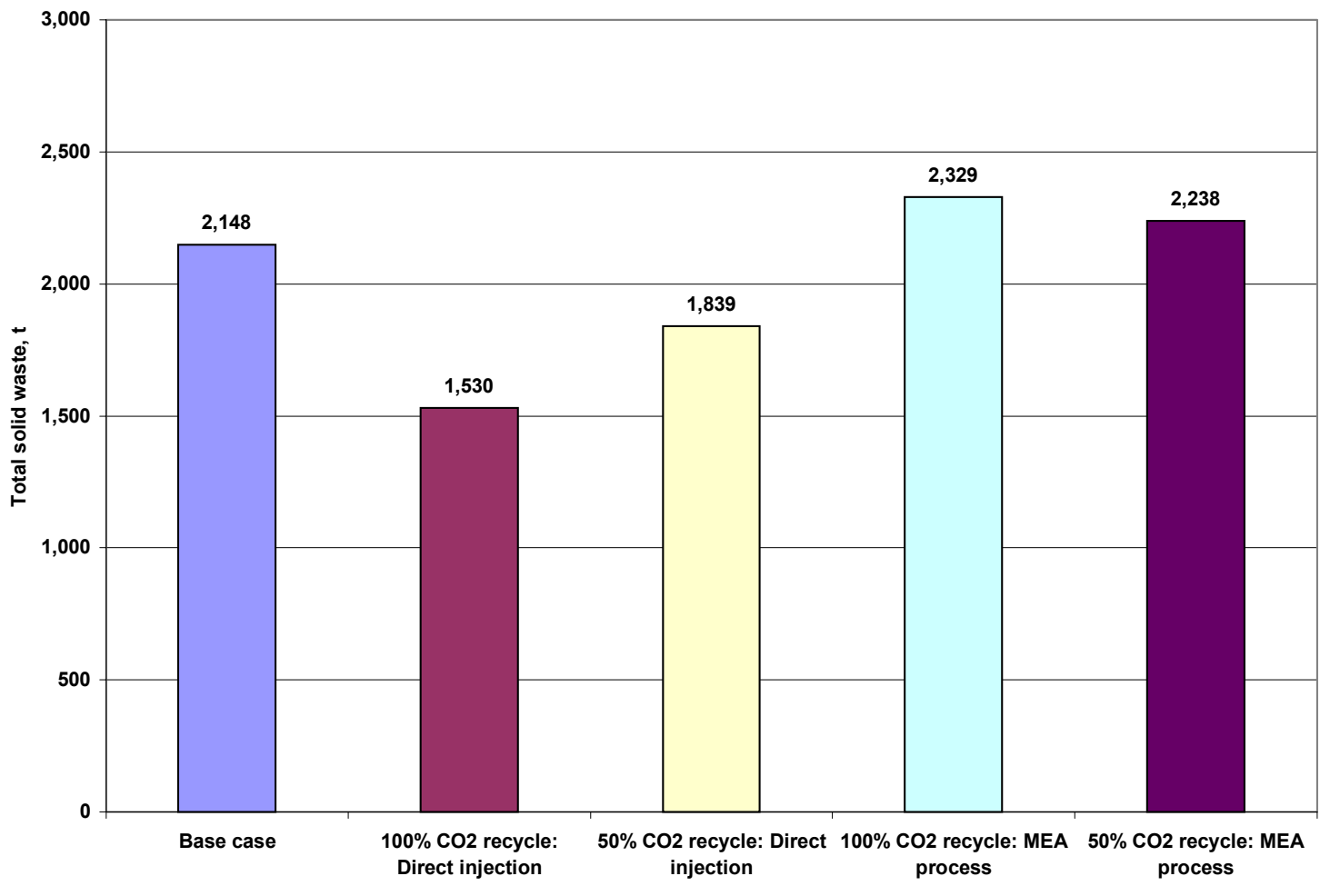

Figure 17. Total solid waste produced for coal firing versus coal/algae cofiring.

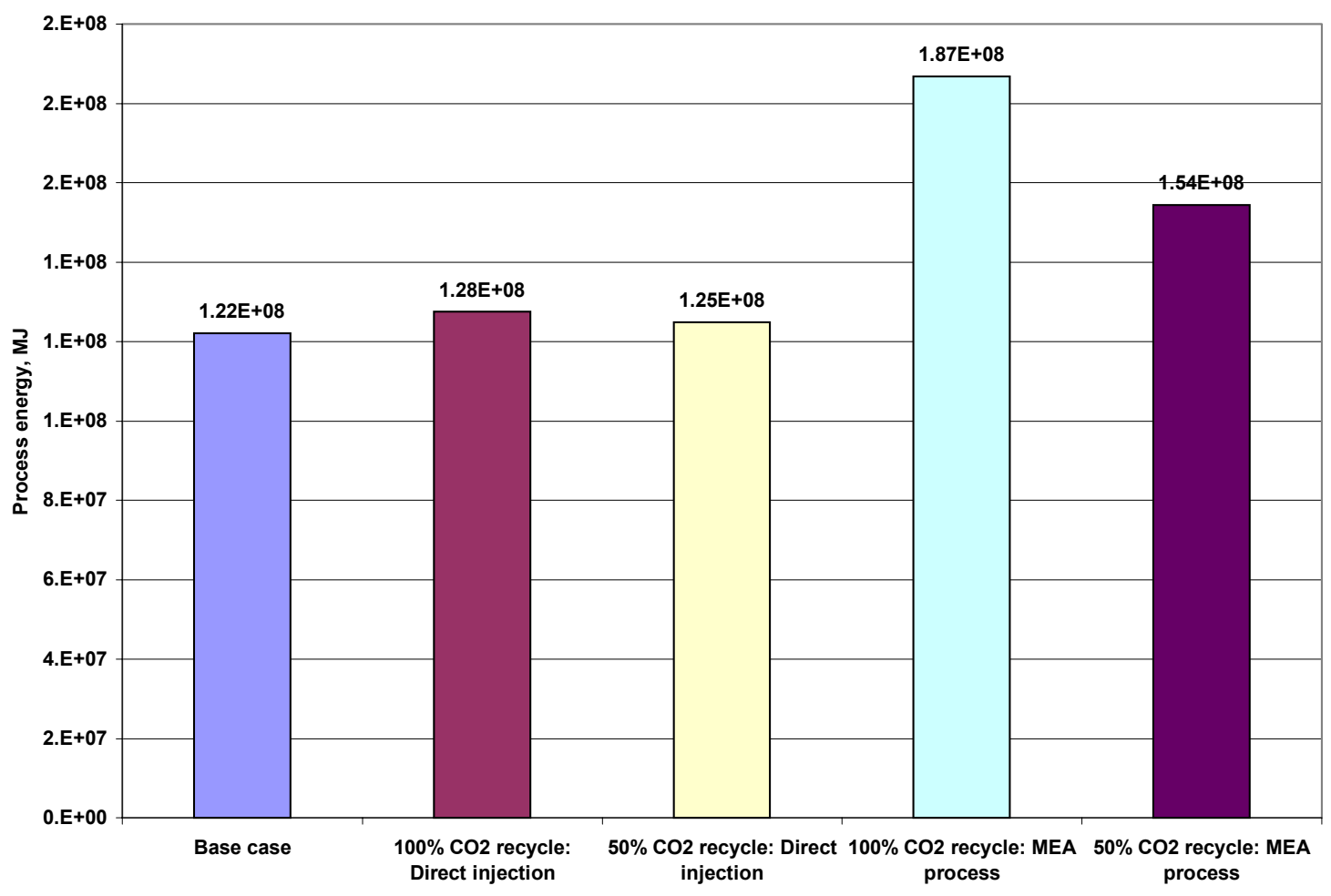

Figure 18. Process energy required for coal firing versus coal/algae cofiring. 
Table 8. Key environmental flows for selected modules: non-renewable resource consumption, air emissions, and waste generation

\begin{tabular}{|c|c|c|c|c|c|c|c|c|}
\hline & Basis & $\begin{array}{c}\text { Coal, } \\
\text { kg }\end{array}$ & $\begin{array}{c}\text { Natural } \\
\text { gas, kg }\end{array}$ & Oil, kg & $\mathrm{CO}, \mathrm{g}$ & $\begin{array}{l}\text { Hydro- } \\
\text { carbons, } \\
\mathrm{g}\end{array}$ & $\begin{array}{c}\text { Total } \\
\text { solid } \\
\text { waste, } k g\end{array}$ & COD, $\mathrm{g}$ \\
\hline Ammonia & $1 \mathrm{~kg}$ & 0.073 & 0.93 & 0.005 & 9.7 & 0.63 & 0.38 & 3.72 \\
\hline $\begin{array}{l}\text { Super } \\
\text { phosphate }\end{array}$ & $1 \mathrm{~kg}$ & 0.001 & 0.96 & 0.63 & 0.41 & 2.6 & 7.35 & 0.02 \\
\hline $\begin{array}{l}\text { Potassium } \\
\text { sulfate }\end{array}$ & $1 \mathrm{~kg}$ & -0.09 & 0.022 & -0.022 & 0.27 & 0.06 & 0.64 & 0.0037 \\
\hline Coal & $1 \mathrm{~kg}$ & 1.009 & $\sim 0$ & 0.006 & 0.2 & 0.04 & 0.28 & 0.014 \\
\hline $\begin{array}{l}\text { Natural } \\
\text { gas }\end{array}$ & $1 \mathrm{~kg}$ & & 1.22 & & 1.83 & 0.82 & & 0.0117 \\
\hline $\begin{array}{l}\text { Steam } \\
\text { (coal) }\end{array}$ & $\begin{array}{l}28 \\
\mathrm{MJ}\end{array}$ & 1.0 & 0 & 0 & 0.3 & 0.016 & 0.0825 & 0.002 \\
\hline $\begin{array}{l}\text { Electricity } \\
\text { (coal) }\end{array}$ & $1 \mathrm{MJ}$ & 0.136 & $\sim 0$ & $\sim 0$ & 0.04 & 0.01 & 0.034 & $\sim 0$ \\
\hline
\end{tabular}

Table 9. Key environmental flows for selected modules: GHG emissions

\begin{tabular}{lcccc}
\hline & Basis & $\begin{array}{c}\text { Carbon Dioxide, } \\
\text { g }\end{array}$ & Methane & $\begin{array}{c}\text { Nitrous } \\
\text { Oxide }\end{array}$ \\
\hline Ammonia & $1 \mathrm{~kg}$ & 2655 & 14 & 0.03 \\
Super phosphate & $1 \mathrm{~kg}$ & 1575 & 12.7 & 0.02 \\
Potassium sulfate & $1 \mathrm{~kg}$ & -370 & 0.06 & 0.005 \\
Coal & $1 \mathrm{~kg}$ & 40.5 & 4.4 & 0.007 \\
Natural gas & $1 \mathrm{~kg}$ & 476 & 18 & 0.004 \\
Steam (coal) & $28 \mathrm{MJ}$ & 2786 & 0.02 & 0.04 \\
Electricity (coal) & $1 \mathrm{MJ}$ & 367 & 0.013 & 0.007 \\
\hline
\end{tabular}

\subsection{LCI for Coal Firing versus Coal/Algae Cofiring: MEA Process}

A comparison of environmental flows for Scenario 2 versus Scenario 1 for the MEA process (using solar drying) is shown in Table 10. Again this table shows values for $100 \%, 75 \%, 50 \%$, and $25 \%$ recycle, and as the $50 \%$ recycle option is the most realistic, the following discussion is limited to this option. 
Table 10. Life cycle inventory for coal firing versus coal/algae cofiring: MEA Process (solar drying)

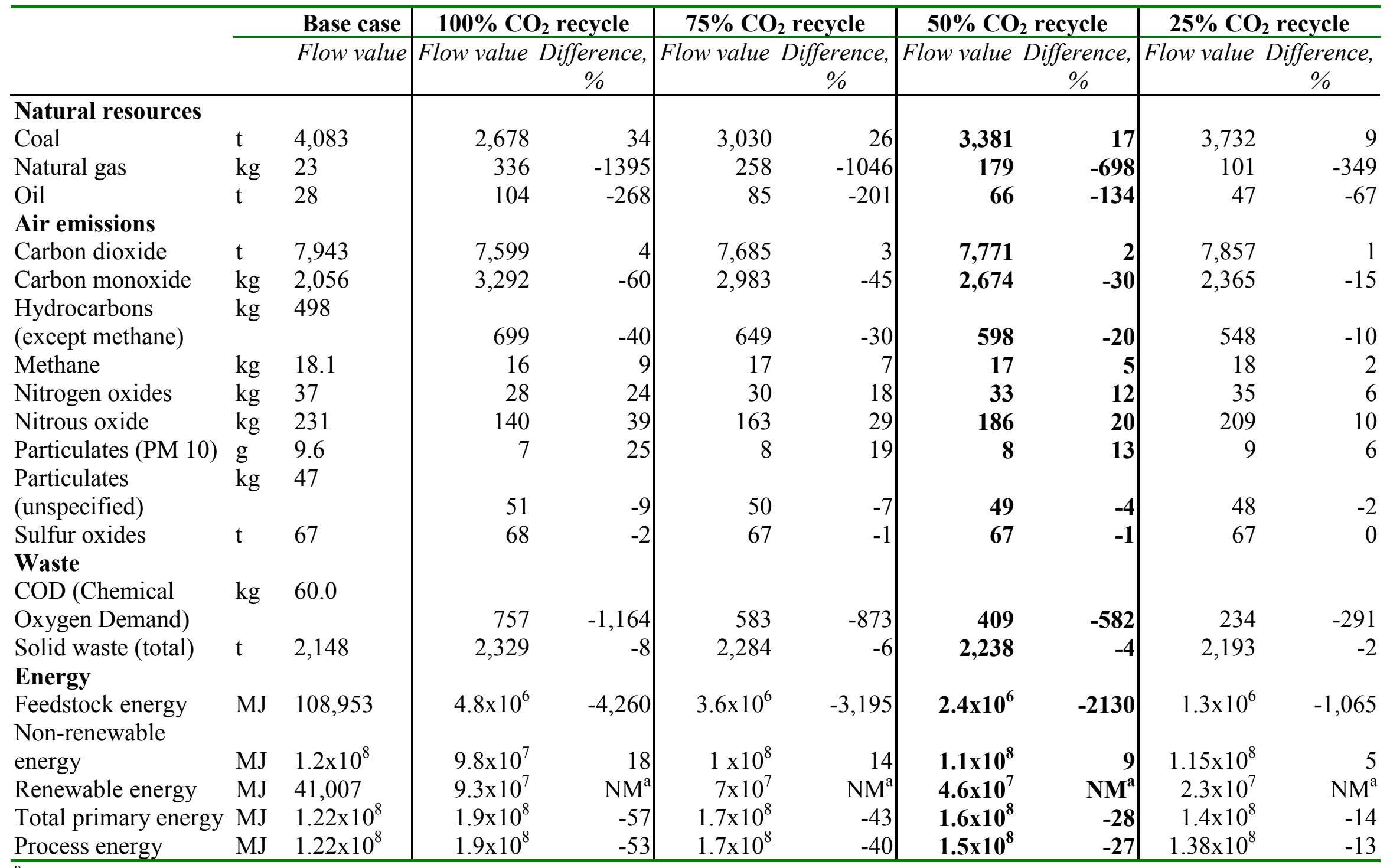

${ }^{a}$ Not meaningful to report. 


\subsubsection{Resource Depletion}

As in the case of the direct injection process, coal consumption is lower but natural gas and oil usage is higher for Scenario 2. The percent increase of natural gas and oil usage is about the same as for the direct injection process since these are mainly consumed during algae cultivation, which is common to both the processes. The percent decrease for coal consumption is lower compared to the direct injection process because of higher steam requirements during MEA extraction.

\subsubsection{Air Pollutants}

Carbon monoxide and hydrocarbons (except methane) emissions for Scenario 2 are higher, by $28 \%$ and $17 \%$, respectively, than those for Scenario 1 . These can be attributed to the higher steam consumption for the MEA process.

\subsubsection{Waste Generation}

COD values are again considerably higher. The percent increase is about the same as for the direct injection process given that the fertilizers are consumed during algae cultivation at the same rate for both the processes. Total solid waste values are comparable for both the scenarios. The increase in total solid waste compared to the direct injection process stems from higher steam consumption in the MEA process.

\subsection{Sensitivity Analysis on Drying Processes}

Solar drying was assumed as a base case scenario. Although this is considered to be a technically feasible approach, a sensitivity analysis on using steam drying was conducted to illustrate the impact of using extra energy for algae drying. A comparison of environmental flows for Scenario 2 versus Scenario 1 using steam drying is shown in Table 11 for the direct injection process and in Table 12 for the MEA process. As expected, the environmental flows related to coal production are higher and the benefits, such as GHG reduction, are lower. Hence, this option would not a feasible one either from economic or environmental standpoint.

\subsection{LCIA for Coal Firing versus Coal/Algae Cofiring}

In addition to the environmental flows, impact indicator values were also calculated for the above scenarios (using solar drying). These indicators are used to give a broader insight into the environmental impacts of the competing scenarios by examining the potential impacts beyond the initial release. The indices calculated are greenhouse potential, natural resources depletion, and acidification potential and eutrophication potential (see Appendix B for definitions).

It is evident from Table 13 and Table 14 that for greenhouse potential and acidification potential, Scenario 1 is worse than Scenario 2, using either of the production schemes. The differences between the two scenarios for the MEA process are, however, not significant. The lower greenhouse potential is mainly because of the $\mathrm{CO}_{2}$ recycle in Scenario 2. Also, the displacement of coal accrues lower $\mathrm{CO}_{2}, \mathrm{SO}_{\mathrm{x}}$, and $\mathrm{NO}_{\mathrm{x}}$ emissions, which coal power plants generate in large amounts. Figures 19 through 22 also graphically depict these environmental impacts. 
Table 11. Life cycle inventory for coal firing versus coal/algae cofiring: Direct injection process (steam drying)

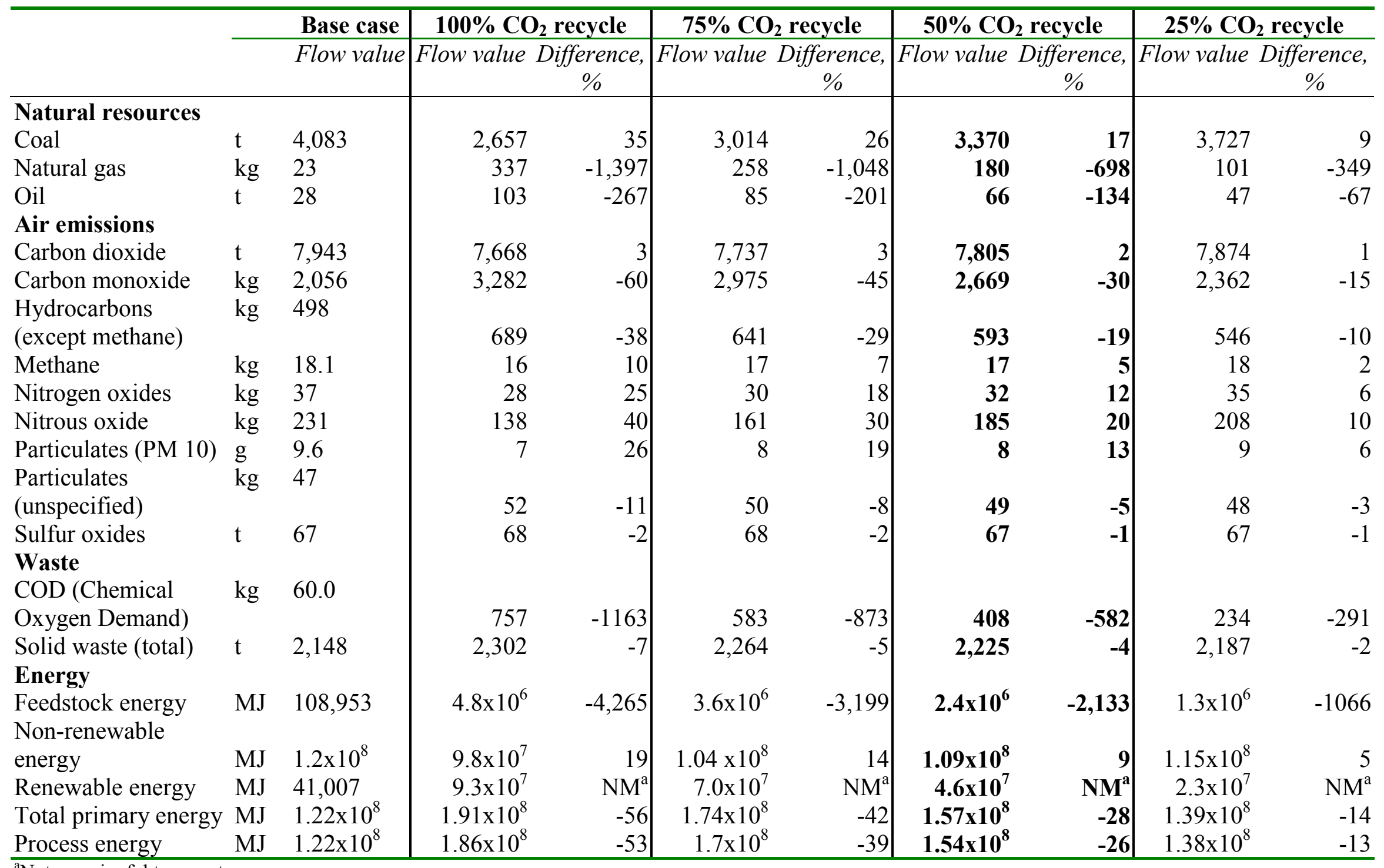

${ }^{a}$ Not meaningful to report. 
Table 12. Life cycle inventory for coal firing versus coal/algae cofiring: MEA process (steam drying)

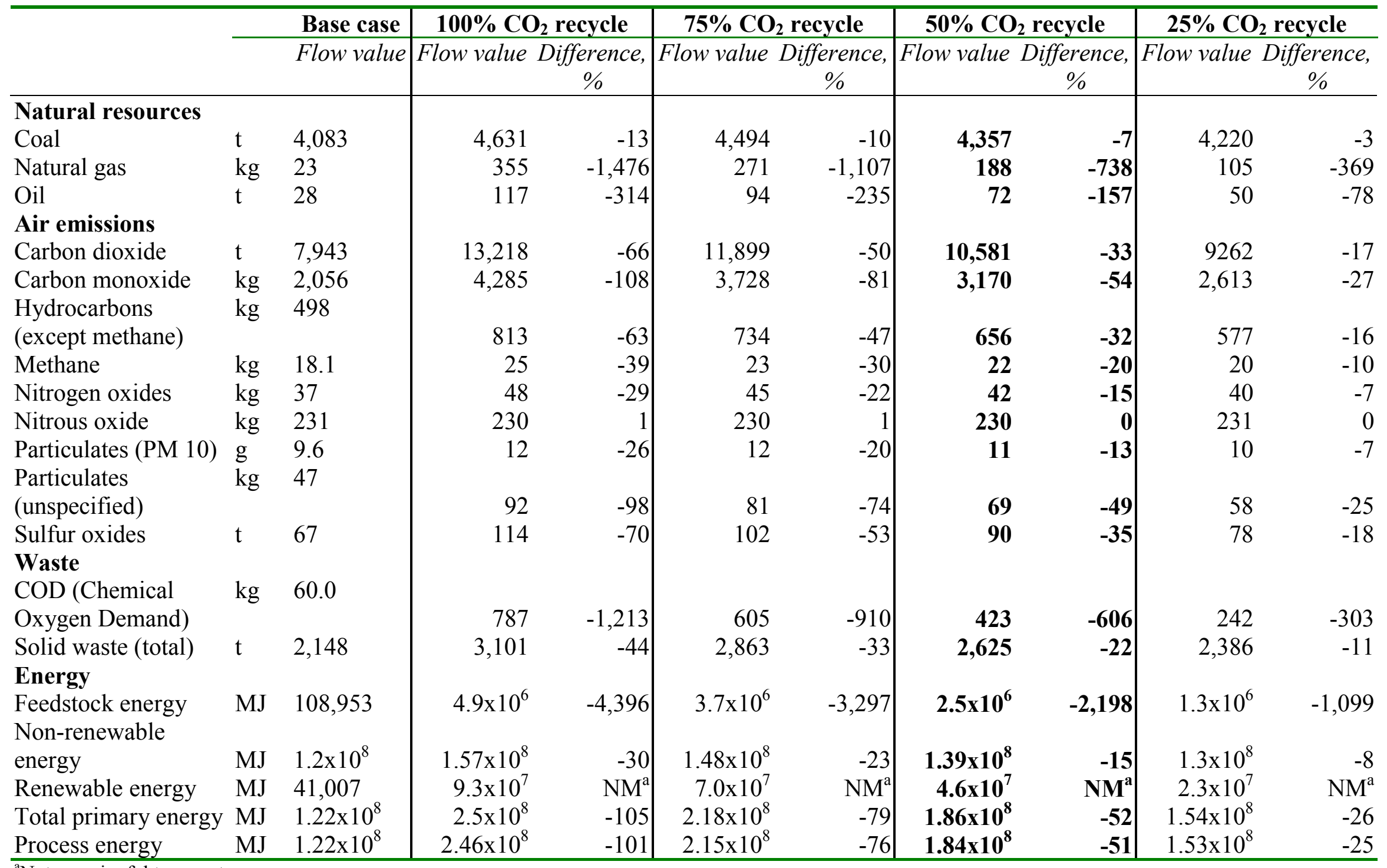

${ }^{a}$ Not meaningful to report. 
Table 13. Life cycle impact assessment for coal firing versus coal/algae cofiring: Direct injection process (solar drying)

\begin{tabular}{|c|c|c|c|c|c|}
\hline Impact indices & \multirow{2}{*}{$\begin{array}{c}\text { Base case } \\
\text { Index value }\end{array}$} & \multicolumn{2}{|c|}{$100 \% \mathrm{CO}_{2}$ recycle } & \multicolumn{2}{|c|}{$50 \% \mathrm{CO}_{2}$ recycle } \\
\hline & & Index value & $\begin{array}{c}\text { Difference, } \\
\%\end{array}$ & Index value & $\begin{array}{c}\text { Difference, } \\
\%\end{array}$ \\
\hline${\text { enhouse effect } \mathrm{t} \mathrm{CO}_{2}}^{\mathrm{a}}$ & 8,460 & 2,248 & 73 & 5,354 & $\mathbf{3 7}$ \\
\hline ir acidification ${ }^{\mathrm{b}} \mathrm{t} \mathrm{H}^{+}$ & 3.0 & 0.9 & 69 & 1.9 & \\
\hline $\begin{array}{l}\text { CML- Depletion of } \\
\text { nonrenewable resources }\end{array}$ & $1.7 \times 10^{-15}$ & $4.13 \times 10^{-14}$ & $-2,301$ & $2.15 \times 10^{-14}$ & $-1,151$ \\
\hline CML-Eutrophication & 4.9 & 16.2 & -232 & 10.5 & -116 \\
\hline
\end{tabular}

${ }^{\mathrm{a}} \mathrm{IPCC}=$ Intergovernment Panel on Climate Change, United Nations.

${ }^{\mathrm{b}} \mathrm{CML}=$ Centre of Environmental Science, Leiden University, The Netherlands.

Table 14. Life cycle impact assessment for coal firing versus coal/algae cofiring: MEA process (solar drying)

\begin{tabular}{|c|c|c|c|c|c|}
\hline Impact indices & \multirow{2}{*}{$\begin{array}{l}\text { Base case } \\
\text { Index value }\end{array}$} & \multicolumn{2}{|c|}{$100 \% \mathrm{CO}_{2}$ recycle } & \multicolumn{2}{|c|}{$50 \% \mathrm{CO}_{2}$ recycle } \\
\hline & & Index value & $\begin{array}{c}\text { Difference, } \\
\%\end{array}$ & Index value & $\begin{array}{c}\text { Difference, } \\
\%\end{array}$ \\
\hline 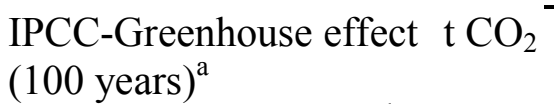 & 8,460 & 8,045 & 5 & 8,253 & \\
\hline CML-Air acidification $^{\mathrm{b}} \quad \mathrm{t} \mathrm{H}^{+}$ & 3.0 & 2.8 & 5 & 2.9 & \\
\hline $\begin{array}{l}\text { CML- Depletion of } \\
\text { nonrenewable resources }^{b}\end{array}$ & $1.7 \times 10^{-15}$ & $4.2 \times 10^{-14}$ & $-2,354$ & $2.2 \times 10^{-14}$ & $-1,177$ \\
\hline CML-Eutrophication $\quad{\mathrm{t} \mathrm{PO}_{4}}$ & 4.9 & 18.8 & -285 & 11.8 & -14 \\
\hline
\end{tabular}

${ }^{\mathrm{a}} \mathrm{IPCC}=$ Intergovernment Panel on Climate Change, United Nations.

${ }^{\mathrm{b}} \mathrm{CML}=$ Centre of Environmental Science, Leiden University, The Netherlands.

The natural resource depletion values are driven to a large degree by how much of a designated natural resource (coal, oil, phosphate, natural gas, uranium, bauxite, iron, etc.) the system consumes. The natural resource depletion values for Scenario 1 are driven by the production of the algae. However, it is not the actual process that is the driver, but rather the upstream emissions from the production of raw materials used in the process (ammonia, super phosphate, potassium sulfate, etc.). 


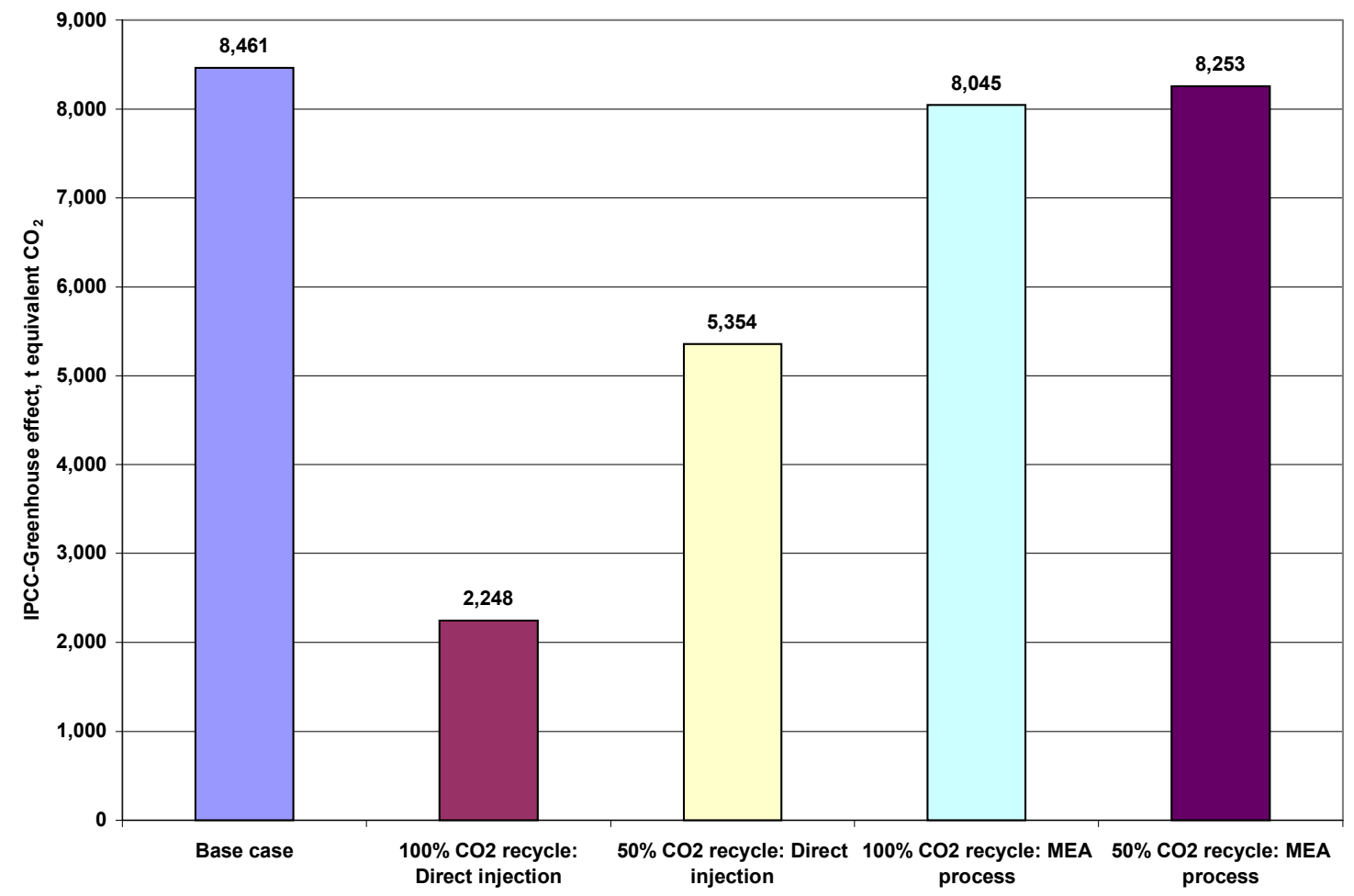

Figure 19. Greenhouse effect for coal firing versus coal/algae cofiring.

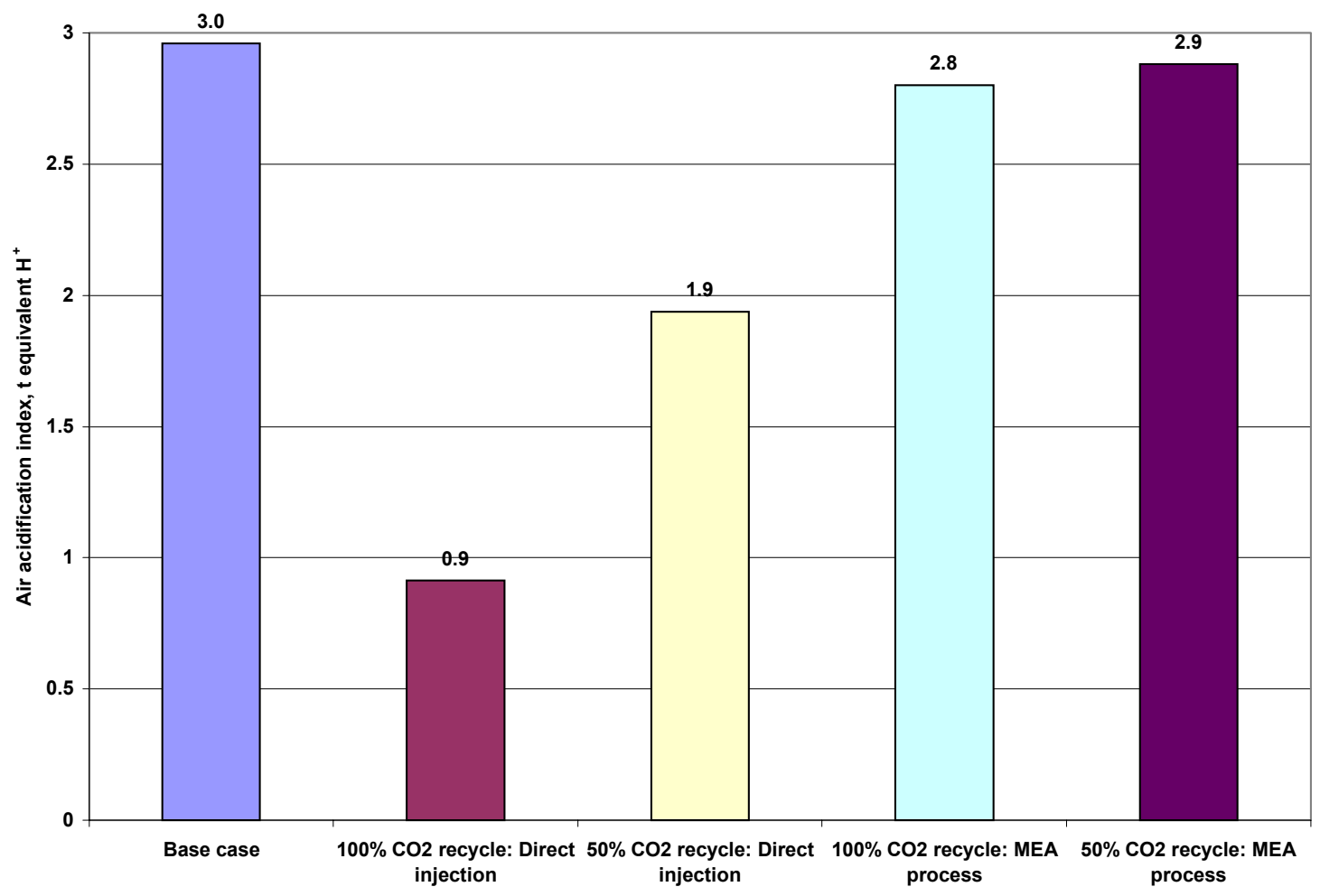

Figure 20. Air acidification potential for coal firing versus coal/algae cofiring. 


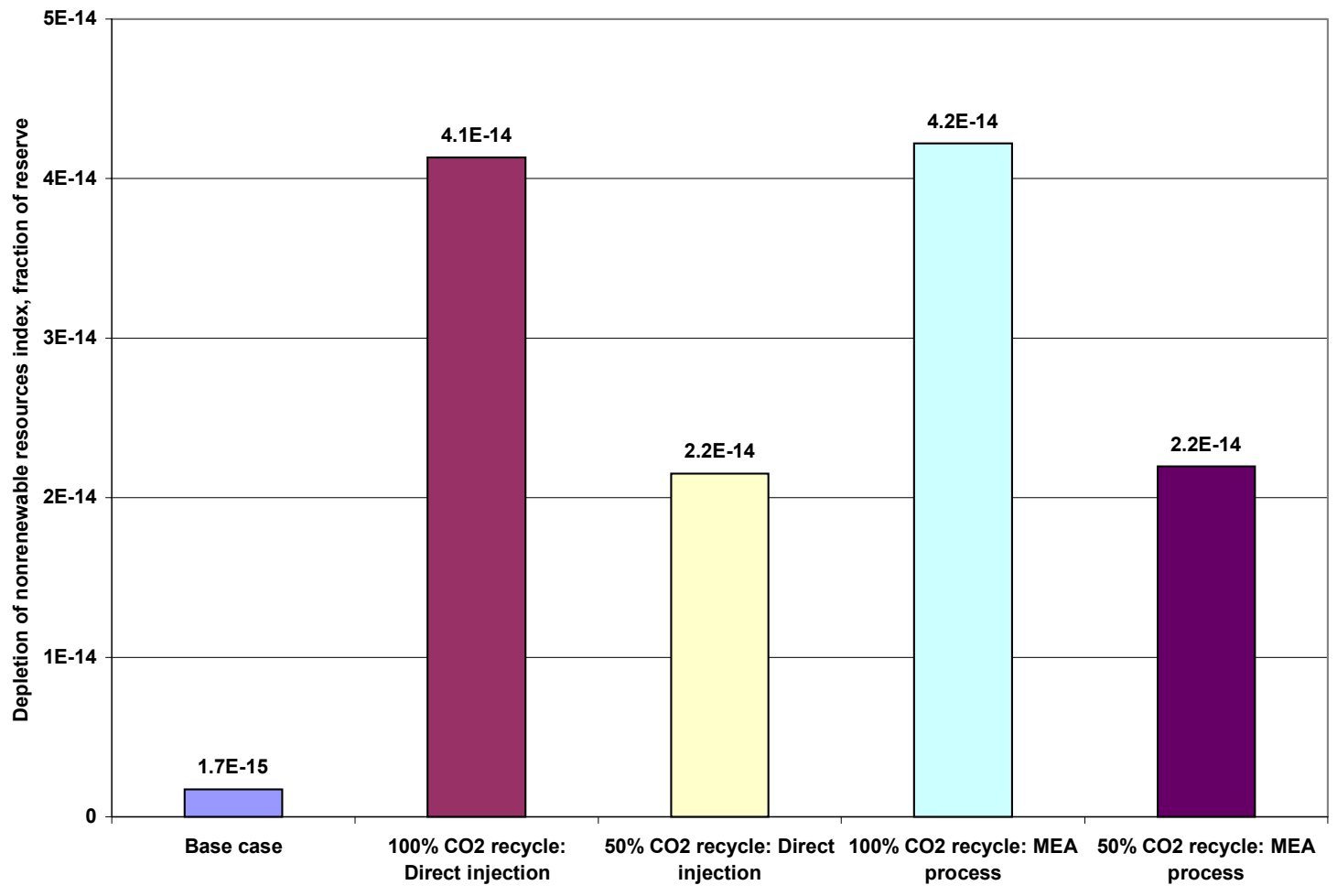

Figure 21. Natural resource depletion potential for coal firing versus coal/algae cofiring.

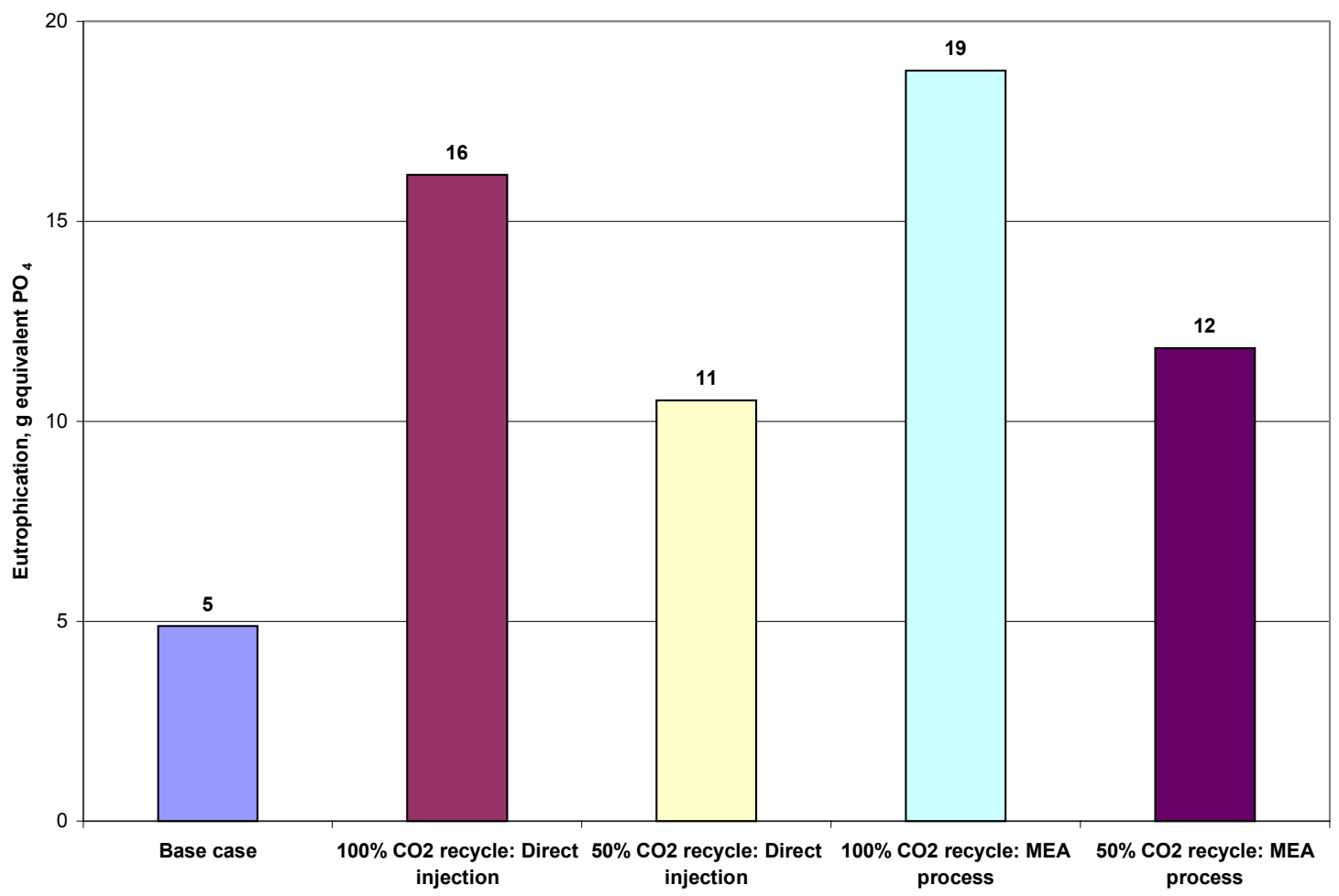

Figure 22. Eutrophication potential for coal firing versus coal/algae cofiring. 
For natural resource depletion and eutrophication potential, Scenario 2 is worse than Scenario 1 by similar extents, using either of the production schemes. Natural resource depletion impact is higher because crude oil and natural gas consumption, which lead to enhanced resource depletion, are more pronounced in algae production, and the index depends on consumption relative to the reserve. The higher depletion of natural resources results from higher consumption of natural gas and oil for Scenario 2, which have lower reserves than coal. Because coal is being displaced by algae, its positive impact on the index is smaller due to its larger reserves. In other words, if a natural gas fired plant were considered, depletion of natural resources would not be as high for Scenario 2. Also, because consumption is divided by a very large number representing the reserve, the higher coal consumption for the MEA process is somewhat tempered. Hence, both the processes have similar burdens in relation to the natural resource depletion impact.

The eutrophication potential values are higher because of fertilizer consumption during algae production, which results in higher CODs and phosphates. Fertilizer is consumed only during algae production. Hence, both the processes have similar burdens pertaining to the eutrophication index.

\section{CONCLUSION}

The LCA performed in this study demonstrates that there are potentially significant benefits to recycling $\mathrm{CO}_{2}$ toward microalgae production. Overall the results show that there are significant differences between Scenarios 1 and $2\left(\mathrm{CO}_{2}\right.$ conversion to algae and cofiring, and coal firing, respectively); the magnitude of these differences varies with the type algae production process.

Based on the LCA results, lower net values for the algae cofiring scenario were observed for the following using the direct injection process (in which the flue gas is directly transported to the algae ponds):

- $\quad \mathrm{SO}_{\mathrm{x}}$ and $\mathrm{NO}_{\mathrm{x}}$

- Particulates

- $\mathrm{CO}_{2}$ and methane

- Fossil energy consumption

Carbon monoxide and hydrocarbons (except methane) emissions were statistically unchanged, i.e., their variation fell within the accuracy of the study. However, the algae cofiring scenario also suffers from higher water-borne emissions as indicated by the COD values.

The four impact assessment categories evaluated-greenhouse potential, depletion of natural resources, air acidification potential, and eutrophication potential-showed mixed results. The lower carbon dioxide and methane emissions, which - although not regulated or mandated by state or national laws - are also desirable attributes as they lead to lower greenhouse potential for the coal/algae cofiring scenario. Lower values for the algae cofiring scenario, when compared to the coal-firing scenario, were also observed for the impact assessment category of air acidification potential. However, impact assessment for depletion of natural resources showed much higher values. The higher depletion of natural resources results from higher consumption of natural gas and oil for Scenario 2, which have lower reserves than coal. As coal is being 
displaced by algae, its positive impact is smaller due to its larger reserves. This means that when comparing to a natural gas fired plant, the relative depletion of natural resources would not be as severe for Scenario 2. The eutrophication potential values are higher because of fertilizer consumption during algae production.

The algae cofiring scenario demonstrates lower GHG (a global unregulated environmental criterion) and air pollutant burdens (local regulated environmental criteria). However, these benefits have to be balanced with higher natural gas and oil use along with a higher eutrophication potential. This LCA affords us an overall picture of impacts across different environmental boundaries. Hence, it can be of help to companies like Rio Tinto Energy Group (a mining/energy company in Australia) and Arizona Public Service that are considering microalgae production as an avenue for GHG mitigation, in their decision-making process.

\section{ACKNOWLEDGMENTS}

This work was supported by the of the National Energy Technology Laboratory, Pittsburgh, PA, USA (U.S. Department of Energy). The author wishes to thank the review panelists (see Appendix C) for their thoughtful review of this report. Vince Camobreco of EPA (formerly of Ecobalance Inc.) and John Sheehan of NREL should be especially mentioned for offering many useful comments and suggestions during this study.

\section{REFERENCES}

Australian Design Hardwoods Pty Ltd. 2000. Company Literature. Gloucester, NSW, Australia.

Booras, G. S. and Smelser, S. C. (2000). "An Engineering and Economic Evaluation of $\mathrm{CO}_{2}$ Removal from Fossil-Fuel-Fired Power-Plants.” (1991). Energy (16); pp. 1295-1305.

Brace Research Institute, (1975). A survey of solar agricultural dryers. Quebec, Canada.

CML. (October 1992). Environmental Life Cycle Assessment of Products: Guide and Backgrounds. Leiden University, The Netherlands: Centre for Environmental Science (CML).

EIA. (December 1999). Annual Energy Outlook 2000. DOE/EIA-0383(2000). Washington, DC: Energy Information Administration (EIA).

EPA. (1993a). Life Cycle Design Manual: Environmental Requirements and the Product System. EPA/600/R-92/226. Washington, DC: U.S. Environmental Protection Agency (EPA).

EPA (1993b). Life-Cycle Assessment: Inventory Guidelines and Principles. EPA/600-R-92-245. Washington, DC: U.S. Environmental Protection Agency (EPA).

EPA (1995a). Guidelines for Assessing the Quality of Life-Cycle Inventory Analysis. EPA/530R-95-010. Washington, DC: U.S. Environmental Protection Agency (EPA).

EPA. (1995b). Emission Factor Documentation for AP-42. Washington, DC: Office of Air Quality Planning and Standards, Office of Air and Radiation, U.S. Environmental Protection Agency (EPA). 
Foster, G. H.; McKenzie, B. A.; DeForest, S. S. (1980). Solar Heat for Grain Drying: Selection, Performance, Management. Report AE-108. West Lafayette, IN: Cooperative Extension Service, Purdue University.

Guinee, J. B. (1995). A Proposal for the Definition of Resource Equivalency Factors for Use in Product Life-Cycle Assessment in Development of a Methodology for the Environmental LifeCycle Assessment of Products. Thesis. University of Leiden, Netherlands: Centre for Environmental Science (CML).

Heijungs, R.; Guinée, J.B.; Huppes, G.; Lankreijer, R.M.; Udo de Haes, H.A.; Wegener Sleeswijk, A.; Ansems, A.M.M.; Eggels, P.G.; van Duin, R.; de Goede, H.P. (October 1992). Environmental Life Cycle Assessment of Products. University of Leiden, Netherlands: Center of Environmental Science.

Herzog, H. Drake, E., and Tester, J. (1993). A Research Needs Assessment for the Capture, Utilization, and Disposal of Carbon Dioxide from Fossil Fuel-Fired Power Plants. Report for DOE Grant No. DE-FG02-92ER30194.A000.

Hong, B. D. and Slatick, E. R. (January-April 1994). "Carbon dioxide emission factors for coal." Quarterly Coal Report, DOE/EIA-0121(94/Q1). Washington, DC: Energy Information Administration; pp. 1-8.

Hughes, E. (2000). "Biomass Cofiring: Economics, Policy and Opportunities." Biomass and Bioenergy (19:6); pp. 457-465.

IPCC. (1994). The 1994 Report of Scientific Assessment Working Group of IPCC. Geneva, Switzerland: Intergovernmental Panel on Climate Change (IPCC), United Nations.

ISO. (1996). Draft International Standard ISO/DIS 14040: Environmental management - Life cycle assessment - Principles and framework. Geneva, Switzerland: International Organization for Standardization (ISO).

ISO. (1997). Draft International Standard ISO/DIS 14041: Environmental management - Life cycle assessment - Goal and scope definition and inventory analysis. Geneva, Switzerland: International Organization for Standardization (ISO).

Kadam, K.L., and Sheehan, J. J. (1996). "Microalgal Technology for Remediation of $\mathrm{CO}_{2}$ from Power Plant Flue Gas: A Technoeconomic Perspective.” World Resource Review (8:4); pp. 493504.

Kadam, K.L. (1997). "Power-Plant Flue Gas as a Source of $\mathrm{CO}_{2}$ for Microalgae Cultivation: Economic Impact of Different Process Options." Energy Convers. Mgmt. (38); pp. S505-S510.

Kadam, K.L.; Camobreco, V. J.; Glazebrook, B.E.; Forrest, L.H.; Jacobson, W.A.; Simeroth, D.C.; Blackburn, W.J.; Nehoda, K.C. (May 1999). Environmental Life Cycle Implications of Fuel Oxygenate Production from California Biomass. NREL/TP-580-25688. Golden, CO: National Renewable Energy Laboratory.

Kadam, K.L.; Brady E. H. (March 1996). "GIS in a Resource Assessment Study for $\mathrm{CO}_{2}$ Mitigation Using Microalgal Technology." Proceedings of the Conference on Geographical Information Systems in Environmental Resource Management, March 13-15, 1996, Reno, Nevada. 
Marchetti, C. (1977) "On Geoengineering and the $\mathrm{CO}_{2}$ Problem," Climatic Change (1); pp. 5968.

SETAC. (1991). A Technical Framework for Life-Cycle Assessments. Washington DC: Society of Environmental Toxicology and Chemistry (SETAC).

SETAC. (1993a). A Conceptual Framework for Life-Cycle Impact Assessment. Washington DC: Society of Environmental Toxicology and Chemistry (SETAC).

SETAC. (1993b). Guidelines for Life-Cycle Assessment: A Code of Practice. Washington DC: Society of Environmental Toxicology and Chemistry (SETAC).

SETAC. (1994) Life Cycle Assessment Data Quality: A Conceptual Framework. Washington DC: Society of Environmental Toxicology and Chemistry (SETAC).

SETAC-Europe. (1992). Life-Cycle Assessment. Brussels, Belgium: Society of Environmental Toxicology and Chemistry, Europe (SETAC-Europe).

Tillman, D. A. (2000a). "Cofiring Benefits for Coal and Biomass." Biomass and Bioenergy (19:6); pp. 363-364.

Tillman, D. A. (2000b). "Biomass Cofiring: the Technology, the Experience, the Combustion Consequences." Biomass and Bioenergy (19:6); pp. 365-384.

USDOE. (July 2000). Carbon Dioxide Emissions from the Generation of Electric Power in the United States. Washington, DC: U.S. Department of Energy (USDOE) and U.S. Environmental Protection Agency.

USDOI. (1994). Mineral Commodity Summary 1994. Washington, DC: Bureau of Mines, U.S. Department of the Interior (USDOI).

Wang, M. (1996). GREET 1.0 - Transportation Fuel Cycles Model: Methodology and Use. Argonne, IL: Argonne National Laboratory, Center for Transportation Research, Energy Systems Division.

WOT. 1990. Solar Energy: Small Scale Applications in Developing Countries. Chapter 2, Solar Dryers. University of Twente, Enschede, The Netherlands: Working Group on Development Techniques (WOT). 


\section{APPENDIX A: SOLAR DRYING}

A background on solar drying in general and a few specific applications are discussed here.

\section{Crop Drying}

In contrast to water heating and the generation of electricity, crop drying utilizes the sun's energy directly. In the tropics, many crops such as cocoa and coffee beans have for decades been dried on racks placed in the sun. Because solar energy is available everywhere, it can be collected and used at the points of greatest need and/or convenience (Brace Research Institute 1975). For crop drying applications, there appears to be little economy of scale in the collection and use of solar energy (Foster et al. 1980). This is beneficial for smaller farms and operations.

Solar energy is an excellent alternative source of supplemental heat for low-temperature grain drying systems. Because these systems require only a few degrees additional temperature rise (5$10^{\circ} \mathrm{F}$ ), they are well adapted to the moderate heat increases that solar energy can economically generate. The fact that solar energy collection is intermittent (i.e., available only when the sun shines) poses less of a problem in drying grain than in comfort heating of a livestock shelter or a home. Solar energy is collected during daylight hours only, which means a variation in drying potential between day and night. But, because low-temperature drying takes several days, the grain can tolerate the varying levels of heat input. "Excess energy" is stored in the form of overdried grain, which at night will absorb excess moisture from high-humidity air, so that drying can proceed. In effect, the batch of grain being dried provides its own solar heat storage.

\section{Solar Dryers}

Most of the information in this section is from the Working Group on Development Techniques (WOT) of the University of Twente, The Netherlands (WOT 1990).

In solar conventional drying, the crop is warmed by the heat from the fire stove, and the air around the heat source is heated up. Under these conditions, the air can take up a great deal of moisture and, by rising, is continually replaced. As the crop, including the air between the plant fibers, is warmed up, the water it contains quickly evaporates. The air within and surrounding the crop is saturated with water vapor. However, the air moving alongside is warm and unsaturated and can take up this moisture and transport it away. A small fan will improve process efficiency, but it is not strictly necessary.

When the air in the room has taken up a certain amount moisture from the crop, the windows mist up (though this will depend on the outside temperature); the air against the cold windows has been cooled to below the dew point. Via this mechanism, water in the crop is transferred to the window panes, where it can be wiped off, or allowed to fall into a gutter, which leads outside the room. If the heat source is replaced by the sun, a solar drier has effectively been described. The cold window, which works as a condenser, is sometimes encountered in indirect drying, where the warming of the air and the drying of the crop are separated, as may happen if the product has been stacked too high or too closely. 


\section{Flat-Plate Collector with Cover}

The principle underlying the solar collector is that "visible light" falling onto a dark object is converted into tangible heat. The color of the object does not need to be black; instead the absorptive qualities of the material determine the effect. A painted plate can be warmed, but so can a suitable fibrous material such as charred rice chaff.

The cover is of secondary importance, but still has a decisive influence on the total working efficiency; it prevents the heat generated from escaping and also limits the heat loss through reradiation. Moreover, it allows a controlled air stream to move over the heated objects, which would not otherwise be possible.

To exploit the energy in the heated objects or surface, a medium (water, air) is directed alongside the object. This takes up the heat and transfers it to the desired destination. When air is used, it can pass under the collector, above it, or through canals embedded within it. It can be a "forced" or a "natural" current. The various possibilities are examined below.

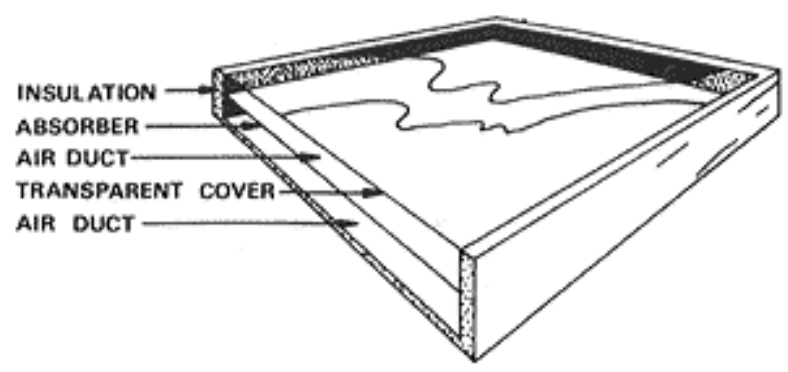

Figure A-1. Simple solar dryer.

\section{Design Elements}

Every solar dryer is constructed using the same basic units (Figure A-1), namely:

- A transparent cover, which admits sunlight and limits heat loss (glass or plastic).

- A dark absorbent surface, which takes up sunlight, converts it to heat, and transfers this heat to the air within or to the product that needs drying.

- An insulating layer underneath.

- An air intake and an outlet, by which means the damper air can be replaced with fresh drier air.

These four elements can be modified if necessary, and/or other elements such as a fan or a chimney may be added. 


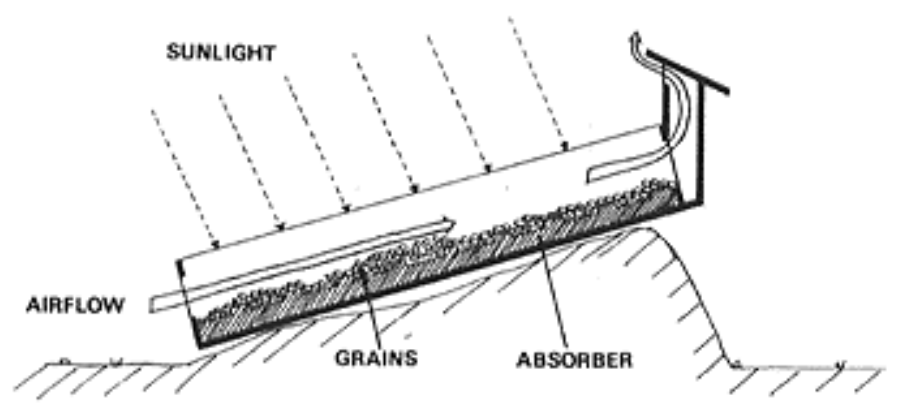

Figure A-2. Solar dryer directly employed.

\section{Direct and Indirect Solar Dryers}

Solar dryers can be divided into two categories:

1. Dryers in which the sunlight is directly employed; heat absorption here primarily by the product itself (Figure A-2).

- Traditional drying racks in the open air.

- Covered racks (protecting against dust and insects).

- Drying boxes provided with insulation and absorptive material.

2. Dryers in which the sunlight is employed indirectly (Figure A-3, Figure A-4).

In this method, the drying air is warmed in a space other than that where the product is stacked. The products, then, are not exposed to direct sunlight. Various designs are possible, and these can be further improved by adding powered fans in order to optimize air circulation.

\section{Solar Energy Storage}

Excess heat generated during the hottest hours of the day can be stored by passing the air through, for example, a container packed with rocks. This only works in forced circulation systems, as the rocks cause considerable pressure loss in the airflow. Storing solar heat in this way allows the excess heat generated by oversized collectors to be used again during the night for more drying.

Such an installation makes it possible to control the air temperature in the drying room, and thus to ensure that the different drying stages work well (for example, for sowing-seeds). In the first drying stage higher temperatures are allowable because of the considerable free water still present in the product. 


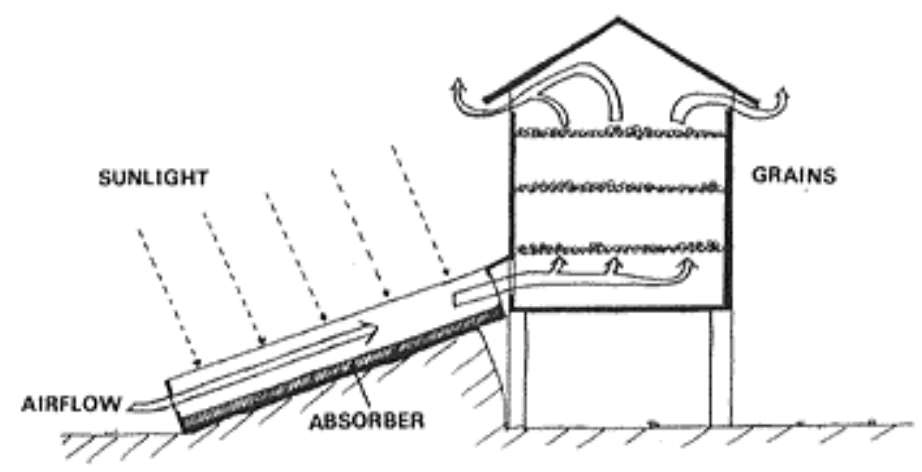

Figure A-3. Solar dryer indirectly employed.

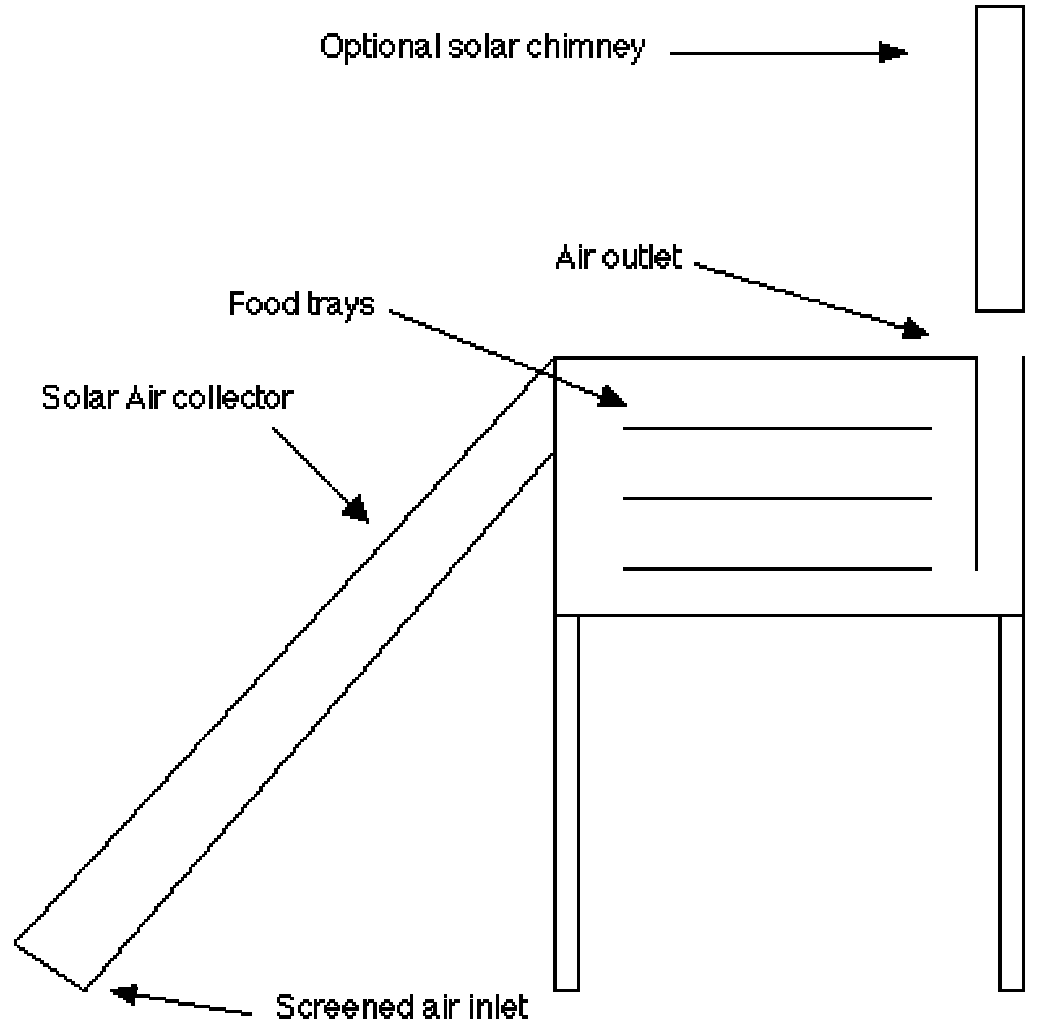

Figure A-4. Schematic of an indirect solar dryer system. 


\section{Solar Kiln}

Solar drying is also used for drying timber, e.g., using a solar kiln. In a solar kiln, incoming light is changed to longer wavelengths (infrared) by the contents of the "hothouse." The longer wavelengths cannot exit the hothouse easily due to insulation and non-emitting plastic film and consequently heat the confines. By utilizing this principle, energy savings are realized in solar kilns as compared to conventional kilns at most sites. For example, when drying hardwoods in summer no auxiliary heat is required for most kiln sizes. The control of humidity allows the drying of green and wet timber at required rates.

The estimated operating costs given below are based on costs incurred for actual kilns in the field in Gloucester, Australia (Australian Design Hardwoods, 2000). These operating costs are for a $4.8 \mathrm{~m}^{3}$ kiln averaged over a 4.5 month. The charge was 2 " hardwood stock of furniture grade.

- Electricity: AU\$175 per month

- Gas: AU\$200-600 per month depending on cloud cover and season

- Loading: 3 h to load the kiln

- Monitoring: $1 \mathrm{~h}$ per week

- Plastic replacement: AU\$700-\$1,000 after 2-3years

This cost estimate is for the slowest and most gentle drying regime, and hence, represents the upper cost limit. This field experience demonstrates the technical and economic feasibility of the solar kiln.

\section{Application to Algae}

Based on the above discussion, it can be fairly concluded that solar drying is technically feasible for algae dewatering. However, actual experimentation and validation of relevant designs will be needed. 


\section{APPENDIX B: IMPACT ASSESSMENT}

\section{Background}

Only recently has the LCA tool actually been concerned with the impacts of a given system on the environment. By definition, the inventory component of an LCA, still the single focus of many LCA studies, is only concerned with the flows generated by the system (either consumed or emitted), and by definition, does not address environmental impacts.

In the most straightforward and transparent approach to LCI interpretation, the LCI results may be used on an $a s$-is basis to help identify and prioritize opportunities for pollution prevention or increases in material and energy efficiency for processes within the life cycle. A particular advantage of LCI applied in this way is its comprehensiveness. LCAs help detect the shifting of environmental burdens from one life cycle stage to another (e.g., lower energy consumption during use, achieved at the cost of much higher manufacturing energy consumption), or from one media to another (e.g., lower air emissions at the cost of increased solid waste). The subsequent stage, LCIA, addresses the issue of how to translate the flows previously compiled into environmental impacts. Some issues viewed as crucial for LCIA are:

- The amount of additional exposure data that would be needed to model actual impacts (as in human health risk assessment) is technically incompatible with the nature of LCA (several hundreds or thousands of processes connected together, each one generating dozens or hundreds of emissions) and does not correspond to its objectives. It should be recognized that LCA is one environmental management tool among several, and that LCA cannot replace a specific environmental impact analysis for a specific site (see Figure B-1).

- Since LCIA aims at assessing potential impacts, LCA should not be considered as a predictive tool for assessing the actual impacts associated with a system, but rather as a tool providing comparative results for the functional unit considered. Moreover, the functional unit often has no reference to time or space considerations (which would be needed for predictive models), but is solely related to the function and performance of a system. As the modeling of environmental impacts improves, potential LCIA models should become increasingly precise and integrate crucial notions such as thresholds (current approaches are all based on a "less-is-better" approach). Consequently, inventory data collection requirements could gradually increase with new parameters characterizing emissions' location, flow rate, key attributes of impacted media, etc.

- Existing approaches that result in a limited number of indices are highly controversial. They have been criticized because they do not separate the objective evaluation stage of the environmental impact on scientific grounds from the subjective "valuation" stage in which these impacts are traded off. Using such approaches is very dangerous from an industrial perspective, due to the following reasons:

* It tends to favor short-term arbitrary choices while masking their arbitrary nature behind quantitative approaches, which convey more rigor and objectivity than are truly involved. This is incompatible with industrial long-term investment and product design.

* The choices made might hide pollution displacement from one media to another or from one step to another. In numerous cases, results of inventory or impact assessments have 
been conclusive enough so that no valuation was actually needed. Moreover, very often, the existence of trade-offs is by itself a crucial piece of information.

- For most impact categories, variability and uncertainties about impact potentials make any single numerical "equivalency factor" immediately contradictable and discreditable. Instead, LCIA methods need to be developed in which process data and results are considered in probabilistic terms. As for inventory results, uncertainties should be propagated and communicated to the decision-making audience.

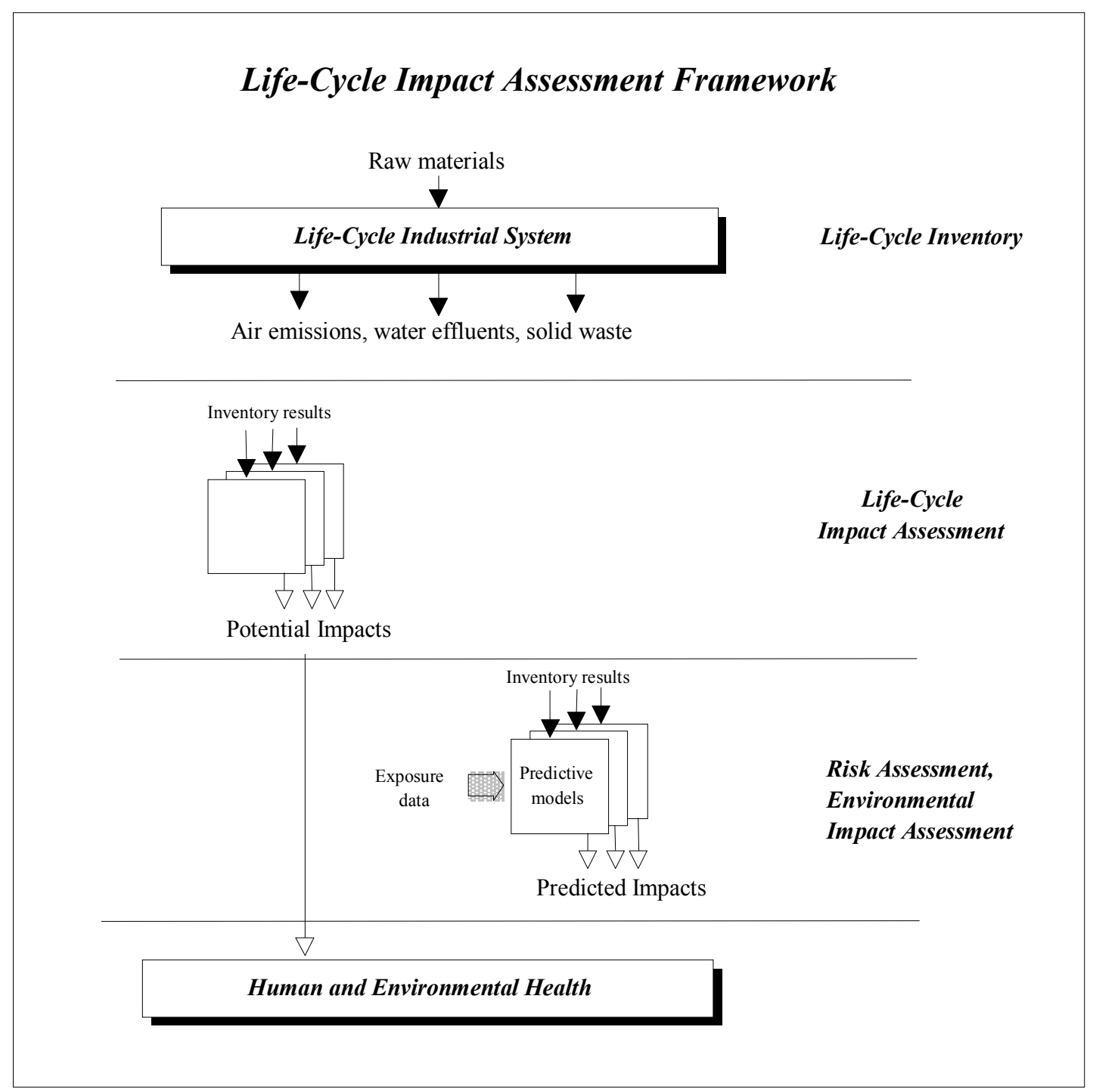

Figure B-1: Life cycle impact assessment framework. 


\section{Overview of Life Cycle Impact Assessment Indices}

\section{Greenhouse Potential}

The Greenhouse potential refers to the ability of some atmospheric gases to retain heat that is radiating from the earth. Models have been developed to quantify the contribution made by emissions of various substances to the greenhouse potential. Generally these models provide an indication of the change in the heat radiation absorption of the atmosphere. Global warming potentials (GWPs) have been calculated to compare the emission of different greenhouse gases (IPCC 1994).

The overall result of emission of these gases on the Greenhouse Potential (E) is calculated as follows:

$$
E=\sum G W P_{i} x m_{i}
$$

where, for a greenhouse gas $i$,

$\mathrm{m}_{\mathrm{i}}$ : the mass of the gas released (in $\mathrm{kg}$ ),

$\mathrm{GWP}_{\mathrm{i}}$ : its potential impact on global warming expressed in grams of $\mathrm{CO}_{2}$ equivalent.

The factors used for calculating the greenhouse potential are listed Table B-1.

Table B-1: Greenhouse gas potential factors

\begin{tabular}{ccc}
\hline Formula & Substance & GWP \\
\hline $\mathrm{CO}_{2}$ & Carbon dioxide & 1 \\
$\mathrm{CH}_{4}$ & Methane & 21 \\
$\mathrm{~N}_{2} \mathrm{O}$ & Nitrous oxide & 310 \\
$\mathrm{CCl}_{4}$ & Carbon & 1,400 \\
& tetrachloride & \\
$\mathrm{CFCl}_{3}$ & CFC 11 & 4,000 \\
\hline
\end{tabular}

The potential impact on global warming of the gas $i$ can be defined as the ratio between the cumulative radiative force between present and a future time horizon (in this case, 20, 100, and 500 years) as a result of the release of a unit mass of greenhouse gas $i$ now, and an equal emission of the standard gas, carbon dioxide. The calculation of the GWP is based on understanding the fate of the emitted gas and the radiative effect associated with the amount remaining in the atmosphere.

\section{Acidification Potential}

Potential acidic deposition (onto soil, vegetation, and water) can be expressed as potential hydrogen ion $\left(\mathrm{H}^{+}\right)$equivalents. Potentially acidifying emissions of $\mathrm{SO}_{2}, \mathrm{NO}_{\mathrm{x}}$, and $\mathrm{NH}_{\mathrm{x}}$ can be aggregated based on their potential to form $\mathrm{H}^{+}$. In the calculation of $\mathrm{H}^{+}$equivalents, it is assumed that one mole $\mathrm{SO}_{2}$ will produce two moles $\mathrm{H}^{+}$, that one mole nitrogen oxide compounds $\left(\mathrm{NO}_{\mathrm{x}}\right)$ 
will produce one mole $\mathrm{H}^{+}$, and that one mole reduced nitrogen compounds $\left(\mathrm{NH}_{\mathrm{x}}\right)$ will produce one mole $\mathrm{H}^{+}$.

An acidification potential (AP) of a substance is calculated based on the number of $\mathrm{H}^{+}$ions that can be produced per mole, given by the stoichiometry of the oxidation reaction (Guinee 1995). However, as emissions are specified in $\mathrm{kg}$ rather than in moles, the weight has to be divided by the molecular weight of the substance.

The factors used for calculating the acidification potential are listed in Table B-2.

Table B-2: Acidification potential reactions

\begin{tabular}{cclc}
\hline Formula & \multicolumn{1}{c}{ Substance } & \multicolumn{1}{c}{ Reaction } & AP \\
\hline $\mathrm{SO}_{2}$ & Sulfur dioxide & $\mathrm{SO}_{2}+\mathrm{H}_{2} \mathrm{O}+\mathrm{O}_{3} \rightarrow 2 \mathrm{H}^{+}+\mathrm{SO}_{4}{ }^{2-}+\mathrm{O}_{2}$ & 32 \\
$\mathrm{NO}_{\mathrm{x}}$ & Nitrogen oxides & $\mathrm{NO}_{2}+\mathrm{OH}^{-} \rightarrow \mathrm{H}^{+}+\mathrm{NO}_{3}{ }^{-}$ & 46 \\
$\mathrm{NH}_{3}$ & Ammonia & $\mathrm{NH}_{3}+2 \mathrm{O}_{2} \rightarrow \mathrm{H}^{+}+\mathrm{NO}_{3}{ }^{-}+\mathrm{H}_{2} \mathrm{O}$ & 17 \\
$\mathrm{HCl}$ & Hydrochloric acid & $\mathrm{HCl} \rightarrow \mathrm{H}^{+}+\mathrm{Cl}^{-}$ & 36.5 \\
$\mathrm{HF}$ & Hydrogen fluoride & $\mathrm{HF} \rightarrow \mathrm{H}^{+}+\mathrm{F}^{-}$ & 20 \\
\hline
\end{tabular}

\section{Eutrophication Potential}

Eutrophication is the addition of mineral nutrients to the soil or water, which increases production of cell biomass. In both media, the addition of mineral nutrients $(\mathrm{N}$ and $\mathrm{P})$ in large quantities result in generally undesirable shifts in the number of species in ecosystems and a reduction in the ecological diversity. In water, it tends to promote the growth of algae, which eventually die and sink to the deeper layers of the water body. The decomposition of this dead cell biomass requires the consumption of large amounts of oxygen, which can result in the death of other aquatic species, such as fish.

Another form of oxygen deficit may be caused by emissions of organic materials that can bind oxygen. These emissions are generally expressed as the COD or the biochemical oxygen demand (BOD). The oxygen is mainly consumed by the biological degradation of organic content. The eutrophication potential (EP) of a substance is calculated based on its potential cell biomass formation. It is calculated in $\mathrm{N}$ equivalents, by considering the average ratio of $\mathrm{N}$ and $\mathrm{P}$ in cell biomass and the oxygen required for the breakdown of this cell biomass. The ratios for $\mathrm{N}$, $\mathrm{P}$, and $\mathrm{O}_{2}$ are 7,1 , and 142, respectively.

EPs are developed by analogy with the GWP. Therefore, phosphate ions have been chosen as the reference substance. A single index is produced for the eutrophication:

$$
E P=\sum E P_{i} x m_{i}
$$


where $m_{i}$ is the weight (in $\mathrm{kg}$ ) of the substance released. The calculated quantity indicates the quantity of a $\mathrm{PO}_{4}$ emission with the same potential eutrophication effect.

The factors used for calculating the eutrophication potential are listed in Table B-3 (CML 1992).

Table B-3: Eutrophication potential factors

\begin{tabular}{ccc}
\hline Formula & Substance & EP \\
\hline $\mathrm{PO}_{4}$ & Phosphates & 1 \\
$\mathrm{P}$ & Phosphorous & 3.06 \\
$\mathrm{~N}$ & Nitrogen & 0.42 \\
$\mathrm{NO}_{\mathrm{x}}$ & Nitrogen Oxides & 0.2 \\
$\mathrm{NH}_{3}$ & Ammonia & 0.42 \\
$\mathrm{COD}$ & Chemical Oxygen & 0.022 \\
\hline
\end{tabular}

\section{Natural Resources Depletion Index}

Resource Depletion as an Environmental Issue

Resource depletion can be defined as the decreasing availability of natural resources. The resources considered in this impact are fossil and mineral resources, excluding biotic resources and associated impacts such as species extinction and loss of biodiversity. It is important to recognize that what is addressed in this index is the fact that some resources are depleted, not the fact that their extraction from the environment will generate impacts (e.g., methane emissions from coal mining).

\section{Corresponding Inventory Flows}

The assessment of natural resources depletion can only be applied to a subset of the LCI flows called elementary flows, i.e., flows that are directly taken from the environment. A coal consumption of $1 \mathrm{~kg}$ at the power plant gate does not correspond to an elementary flow. Rather, it corresponds to a consumption of approximately $1.03 \mathrm{~kg}$ of coal in the ground, due to the losses in mining, processing, and transportation.

Availability Defined

The notion of availability can be further defined. Natural resource depletion does not take into account the availability within the economy, but rather the availability within the "natural" environment. Excluded from this impact are "economic stocks" such as aluminum from aluminum cans or steel from used car bodies. Therefore, the availability is not measured within the whole economy, but only at the economy/environment "boundary." Furthermore, the availability is concerned with the availability within the primary extraction medium (e.g., iron ore available from the earth's crust) and not within the entire geosphere (which would include iron available in water bodies, atmosphere, plants, landfills, etc.).

Resource versus Reserve

Once the concept of availability has been defined, the notion of reserve of a resource needs also to be determined. Through the years, geologists, mining engineers, and others operating in the 
mineral field have used various terms to describe and classify mineral resources. Known resources can be classified from two standpoints: 1) purely geologic or physical/chemical characteristics - such as grade, tonnage, thickness, and depth — of the material in place, and 2) profitability analyses based on costs of extracting and marketing the material in a given economy at a given time. The former constitutes important objective scientific information of the resource and a relatively unchanging foundation upon which the latter economic delineation can be based.

For mineral resources, the reserve chosen for this index is the reserve base as defined by the U.S. Bureau of Mines (USDOI 1994): reserve base is "part of an identified ${ }^{4}$ reserve that meets specified minimum physical and chemical criteria related to current mining and production practices, including those for grade, quality thickness, and depth. The reserve base encompasses those parts of the resources that have a reasonable potential for becoming economically available within planning horizons beyond those that assume proven technology and current economics. It includes those resources that are currently economic (reserve), marginally economic (marginal reserves) and currently sub-economic." By including economic and sub-economic considerations, the reserve base falls between the two extremes of economic reserve and ultimate reserve/resource base.

For fossil fuels (including uranium), the reserve chosen is based on information supplied by the World Energy Council (WEC). In order to be consistent with the reserve base used by the U.S. Bureau of Mines, the reserve chosen for fossil fuels has been defined as the addition of the WEC's "proved amount in place" (tonnage in place that has been both carefully measured and has also been assessed as exploitable under present and expected local economic conditions with existing available technology) and "estimated additional reserves recoverable" (quantity of the estimated additional amount in place that might become recoverable within foreseeable economic and technological limits).

It should be noted that what matters most in this impact assessment index is the availability of a relative scale allowing comparisons between resources rather than an estimation of the exact size of what is considered available for use. This is linked to the fact that impact assessment as performed within an LCA is of a comparative rather than predictive nature. It aims at assessing the relative potential impacts of different alternatives (i.e., natural resource depletion index of option A versus option B) rather than assessing the actual impacts of a system onto the environment (as it would be done in traditional risk assessment).

\section{Index Definition}

Once the type of reserve is identified, an index can be defined that will relate an inventory flow with the depletion of that resource. The proposed depletion index uses equivalency factors, i.e., each natural resource consumption recorded in the inventory is multiplied by the resource's weighting factor (or equivalency factor). As described in equation (1) below, the total depletion index is then compiled by adding the previous intermediate results for all inventory flows considered.

\footnotetext{
${ }^{4}$ As opposed to identified resources are undiscovered resources, the existence of which is only postulated.
} 
Several methods can be used to produce the equivalency factors. In the first method described in equation (2), the inverse of reserve (in $\mathrm{kg}$ ) is used as a weighting factor. Such an index addresses the relative contribution of the LCA system to the depletion of the reserves (the larger the relative contribution, the bigger the index) as well as the size of the reserve (the larger the reserve, the smaller the index). However, it does not address the following problem: how long a given resource will continue to be available (the fact that the reserve is rapidly or slowly being depleted, which is directly related to the notion of sustainability, is not accounted for in this index).

In the second method, described in equation (3), the inverse of remaining years of use is used as a weighting factor. The number of remaining years of use is defined as the reserves divided by the total world-wide production (i.e., extraction). It represents the number of years for which current reserves will suffice at the current production (extraction) level. This index, however, does not correctly account for the size of the reserve: two resources with the same number of years will have the same indices irrespective of whether there are $1 \mathrm{~kg}$ or 1 million $\mathrm{t}$ reserves.

In the third method described in equation (4) and retained as a basis for the index, the inverse of remaining years of use and the reserve size are used as weighting factors. This index addresses both problems that were raised by the first two methods. It should be noted, however, that choosing higher (e.g., cubic) power for the reserve and production could generate a number of similar indices. ${ }^{5}$ Since there is no rational basis for doing so, the index has been kept as in equation (4). In order to facilitate the readability of the results, all equivalency factors have been multiplied by $10^{15}$ (as explained previously, the relative contribution of each resource is what matters most).

(1) Depletion $=\sum_{r e s}$ equivalency factor $r_{r e s} x$ inventory consumption ${ }_{r e s}$

(2) Depletion $=\sum_{\text {res }} \frac{1}{\text { reserve }_{\text {res }}} \times$ inventoryconsumption $n_{\text {res }}$

(3) Depletion $=\sum_{\gamma e s} \frac{1}{\text { years }_{r e s}} \times$ inventoryconsumption $_{r e s}=\sum_{\gamma e s} \frac{\text { production }_{r e s}}{\text { reserve }_{r e s}} \times$ inventoryconsumption $_{r e s}$

(4) Depletion $=\sum_{\text {res }} \frac{1}{\text { reserve }_{r e s} x \text { years }} \times$ inventory consumption $_{r e s}=\sum_{r e s} \frac{\text { production }_{r e s}}{\left(\text { reserve }_{r s s}\right)^{2}} \times$ inventoryconsumption $_{r e s}$

\footnotetext{
5 It has been shown that in order to keep the index independent of the resource density, the power of the reserve should be the power of the production plus one, which is the case in equation (4).
} 


\section{APPENDIX C: PROJECT REVIEW}

The draft Final Report (which contained the LCA results, as well as the scoping decisions and data summary) was reviewed by the following panel. Their comments were incorporated into the final version.

John Benemann

(Private Consultant)

3434 Tice Creek Dr., \#1

Walnut Creek, CA 94595

Telephone: 510939 5864; Fax: 5109395864

e-mail: JBenemann@aol.com

Vince Camobreco

During the review, with Ecobalance Inc., Bethesda, Maryland 20814.

Currently, with Environmental Protection Agency

1200 Pennsylvania Ave. NW

Washington, DC 20460

Mail Code 6202J

Telephone: 202 564-9043, Fax: 202 565-2079

e-mail: camobreco.vincent@epamail.epa.gov

John Sheehan

National Renewable Energy Laboratory

1617 Cole Blvd.

Golden, Colorado 80401

Telephone: 303 384-6136, Fax: 303 384-6877

e-mail: John_Sheehan@nrel.gov 
Public reporting burden for this collection of information is estimated to average 1 hour per response, including the time for reviewing instructions, searching existing data sources,

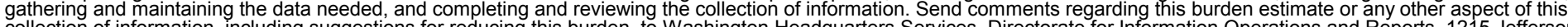
Davis Highway, Suite 1204, Arlington, VA 22202-4302, and to the Office of Management and Budget, Paperwork Reduction Project (0704-0188), Washington, DC 20503.

\begin{tabular}{|l|l|l}
\hline 1. AGENCY USE ONLY (Leave blank) & $\begin{array}{l}\text { 2. REPORT DATE } \\
\text { June 2001 }\end{array}$ & $\begin{array}{l}\text { 3. REPORT TYPE AND DATES COVERED } \\
\text { Technical Report }\end{array}$ \\
\hline
\end{tabular}
4. TITLE AND SUBTITLE
Microalgae Production from Power Plant Flue Gas: Environmental Implications on a Life Cycle Basis

5. FUNDING NUMBERS DO11.4010

\author{
6. $\mathrm{AUTHOR}(\mathrm{S})$ \\ Kiran L. Kadam
}

7. PERFORMING ORGANIZATION NAME(S) AND ADDRESS(ES)

8. PERFORMING ORGANIZATION REPORT NUMBER

9. SPONSORING/MONITORING AGENCY NAME(S) AND ADDRESS(ES) National Renewable Energy Laboratory 1617 Cole Blvd. Golden, CO 80401-3393

10. SPONSORING/MONITORING AGENCY REPORT NUMBER NREL/TP-510-29417

11. SUPPLEMENTARY NOTES

12a. DISTRIBUTION/AVAILABILITY STATEMENT

National Technical Information Service

U.S. Department of Commerce

5285 Port Royal Road

Springfield, VA 22161 12b. DISTRIBUTION CODE

13. ABSTRACT (Maximum 200 words)

Power-plant flue gas can serve as a source of $\mathrm{CO}_{2}$ for microalgae cultivation, and the algae can be cofired with coal. This life cycle assessment (LCA) compared the environmental impacts of electricity production via coal firing versus coal/algae cofiring. The LCA results demonstrated lower net values for the algae cofiring scenario for the following using the direct injection process (in which the flue gas is directly transported to the algae ponds): $\mathrm{SO}_{\mathrm{x}}, \mathrm{NO}_{\mathrm{x}}$, particulates, carbon dioxide, methane, and fossil energy consumption. Carbon monoxide, hydrocarbons emissions were statistically unchanged. Lower values for the algae cofiring scenario, when compared to the burning scenario, were observed for greenhouse potential and air acidification potential. However, impact assessment for depletion of natural resources and eutrophication potential showed much higher values. This LCA gives us an overall picture of impacts across different environmental boundaries, and hence, can help in the decision-making process for implementation of the algae scenario.

14. SUBJECT TERMS

15. NUMBER OF PAGES

microalgae; carbon dioxide; power generation; cofiring; life cycle assessment

16. PRICE CODE

17. SECURITY CLASSIFICATION OF REPORT

Unclassified
18. SECURITY CLASSIFICATION
OF THIS PAGE Unclassified
19. SECURITY CLASSIFICATION OF ABSTRACT Unclassified
20. LIMITATION OF ABSTRACT

UL 